\title{
Peptides: Production, bioactivity, functionality, and applications
}

Hajfathalian, Mona; Ghelichi, Sakhi; García Moreno, Pedro Jesús; Sørensen, Ann-Dorit Moltke; Jacobsen, Charlotte

\section{Published in:}

Critical Reviews in Food Science and Nutrition

Link to article, DOI:

$10.1080 / 10408398.2017 .1352564$

Publication date:

2018

Document Version

Publisher's PDF, also known as Version of record

Link back to DTU Orbit

Citation (APA):

Hajfathalian, M., Ghelichi, S., García Moreno, P. J., Sørensen, A-D. M., \& Jacobsen, C. (2018). Peptides: Production, bioactivity, functionality, and applications. Critical Reviews in Food Science and Nutrition, 58(18), 3097-3129. https://doi.org/10.1080/10408398.2017.1352564

\section{General rights}

Copyright and moral rights for the publications made accessible in the public portal are retained by the authors and/or other copyright owners and it is a condition of accessing publications that users recognise and abide by the legal requirements associated with these rights.

- Users may download and print one copy of any publication from the public portal for the purpose of private study or research.

- You may not further distribute the material or use it for any profit-making activity or commercial gain

- You may freely distribute the URL identifying the publication in the public portal 


\section{Critical Reviews in Food Science and Nutrition}

ISSN: 1040-8398 (Print) 1549-7852 (Online) Journal homepage: https://www.tandfonline.com/loi/bfsn20

\section{Peptides: Production, bioactivity, functionality, and applications}

\section{Mona Hajfathalian, Sakhi Ghelichi, Pedro J. García-Moreno, Ann-Dorit Moltke Sørensen \& Charlotte Jacobsen}

To cite this article: Mona Hajfathalian, Sakhi Ghelichi, Pedro J. García-Moreno, Ann-Dorit Moltke Sørensen \& Charlotte Jacobsen (2018) Peptides: Production, bioactivity, functionality, and applications, Critical Reviews in Food Science and Nutrition, 58:18, 3097-3129, DOI: 10.1080/10408398.2017.1352564

To link to this article: https://doi.org/10.1080/10408398.2017.1352564

曲 Published online: 11 Oct 2017.

Submit your article to this journal $\pi$

Џ Article views: 408

View Crossmark data ¿

Citing articles: 5 View citing articles $\square$ 


\title{
Peptides: Production, bioactivity, functionality, and applications
}

\author{
Mona Hajfathalian ${ }^{a}$, Sakhi Ghelichi ${ }^{\mathrm{a}, \mathrm{b}}$, Pedro J. García-Moreno ${ }^{\mathrm{a}}$, Ann-Dorit Moltke Sørensen ${ }^{\mathrm{a}}$, and Charlotte Jacobsen ${ }^{\mathrm{a}}$ \\ ${ }^{a}$ Division of Food Technology, National Food Institute, Technical University of Denmark, 2800 Kgs. Lyngby, Denmark; ${ }^{b}$ Department of Seafood Science \\ and Technology, Faculty of Fisheries and Environmental Science, Gorgan University of Agricultural Sciences and Natural Resources, Gorgan, Iran
}

\begin{abstract}
Production of peptides with various effects from proteins of different sources continues to receive academic attention. Researchers of different disciplines are putting increasing efforts to produce bioactive and functional peptides from different sources such as plants, animals, and food industry by-products. The aim of this review is to introduce production methods of hydrolysates and peptides and provide a comprehensive overview of their bioactivity in terms of their effects on immune, cardiovascular, nervous, and gastrointestinal systems. Moreover, functional and antioxidant properties of hydrolysates and isolated peptides are reviewed. Finally, industrial and commercial applications of bioactive peptides including their use in nutrition and production of pharmaceuticals and nutraceuticals are discussed.
\end{abstract}

\section{KEYWORDS}

Peptides; hydrolysate; bioactivity; functional properties; antioxidant properties; application

\section{Introduction}

Dietary protein is an important source of energy (4 kcal/g protein) and essential amino acids, which are needed for growth and maintenance of physiological functions such as repair of tissues and cell signaling. In the body, proteins are broken down to peptides upon digestion by endogenous enzymes in the gastrointestinal system. These peptides are inactive within the sequence of the parent protein, but after they are released by enzymatic hydrolysis, they exert various physiological functions. Recent research has shown that peptides from different sources such as dairy products, plants, animals and seafood have a wide range of bioactivities, e.g., antimicrobial (Tang et al., 2015), immunomodulatory (Mechkarska et al., 2014), antihypertensive (Capriotti et al., 2015), and antioxidant (Babini et al., 2017) activities, among others.

Bioactive peptides can also be produced by commercial exogenous enzymes, which hydrolyze proteins into peptides. The greatest number of bioactive peptides isolated to date is from milk proteins. Other sources include meat, fish, eggs, plant sources such as soy and wheat (Hartmann and Meisel, 2007). The most commonly used enzymes for the production of bioactive peptides, for instance, from fish proteins include Alcalase 2.4 L FG, Papain, Pepsin, Trypsin, $\alpha$-chymotrypsin, Pancreatin, Flavourzyme, Pronase, Neutrase, Protamex, Bromelain, Cryotin F, Protease N, Protease A, Orientase, Thermolysin, and Validase (Raghavan and Kristinsson, 2008; Ren et al., 2008; Samaranayaka and Li-chan, 2008; Je et al., 2009; Hsu, 2010; Ngo et al., 2010). Some of these enzymes are also used for production of bioactive peptides from other sources.

A large proportion of the global production of dietary proteins is being discarded as waste or sold at a low price for animal feed after the main products have been produced from the original raw material. For example, rapeseed meal with a low solubility is produced as a by-product from the production of rapeseed oil (Tan et al., 2011). Likewise, head, bones, tails and intestines are by-products from the seafood production, which currently provide the manufacturer with low or no revenue. Therefore, it seems crucial to find avenues toward making the best use of such protein sources, for example by using them for the production of protein hydrolysates containing bioactive peptides for human consumption (Sila and Bougatef, 2016). One of the challenges associated with this strategy is the removal of bitterness from such peptide formulations because the bitterness negatively affects consumer perception (Zhao et al., 2015).

Protein hydrolysates and peptides from natural resources can be used as "functional foods" and "nutraceuticals" on the basis of their bioactivity, or as technological components thanks to their functional properties. The functional products and nutraceuticals may contain the whole hydrolysate and/or isolated and purified peptides (Lafarga et al., 2016). Since the bioactivity and functionality of peptides depend on their amino acid composition, sequence, and molecular mass (Lassoued et al., 2015a), peptides with varying effects might be derived from a single hydrolysate. Therefore, sometimes additional stages of isolation and purification are required in order to incorporate peptide(s) with intended effect(s) in the final product. This isolation process is predominantly carried out by controlling the process of enzymolysis (Zou et al., 2016).

This review aims to provide an overview of state-of-the-art technologies for the production and purification of protein hydrolysates including technologies for the removal of bitterness. A second aim is to provide a comprehensive overview of the activities that have been reported for protein hydrolysates from various protein sources such as dairy, egg, animal, fish, and plants. The review will cover bioactivities with a potential 
impact on human health including effects on the immune, cardiovascular, nervous and gastrointestinal systems. Functional properties of protein hydrolysates such as emulsifying, water binding, and antioxidant properties in foods will also be discussed. A final aim of the review is to critically assess potential applications of protein hydrolysates/bioactive peptides in pharmaceutical, sports nutrition, food and feed applications on the basis of the current knowledge and documentation of their bioactivity.

\section{Production of bioactive and functional peptides}

In order to exhibit their beneficial effects on health, bioactive peptides must be released from the primary structure of food proteins, where they remain bonded to other amino acids. Moreover, protein hydrolysis can also lead to hydrolysates with improved techno-functional properties (e.g., solubility, emulsifying, foaming, oil and water binding, and gelling) (Wouters et al., 2016). The release of bioactive peptides is achieved by degrading the original proteins by using chemicals (e.g., acids and alkalis) or enzymes. Proteolysis caused by enzymes is preferred to chemical hydrolysis since: (i) the reaction is carried out at mild conditions of $\mathrm{pH}$ (e.g., 4-8) and temperature (e.g., $40-60^{\circ} \mathrm{C}$ ), (ii) side reactions are avoided because of the high specificity of the enzymes, and (iii) the peptides obtained maintain their nutritional value (Guerard, 2006). Therefore, this review focuses on the production of bioactive peptides by enzymatic hydrolysis, including fermentation where enzymes are secreted by the microorganism(s) taking part in the process. Technologies for removal of bitterness are also discussed. In addition, the fractionation, purification and identification of bioactive peptides, including bioinformatics-driven approaches, are covered in this section.

\section{Enzymatic protein hydrolysis}

Enzymatic hydrolysis of proteins is catalyzed by proteases, which cleave peptide bonds between two amino acids consuming a molecule of water per bond cleaved (Eq. 1). Hence, the continuous cleavage of peptide bonds breaks down proteins into products of lower molecular weight such as peptones, peptides, and amino acids (Adler-Nissen, 1986).

$$
\mathrm{P} 1-\mathrm{CO}-\mathrm{NH}-\mathrm{P} 2 \rightarrow \mathrm{P} 1-\mathrm{COOH}+\mathrm{P} 2-\mathrm{NH}_{2}
$$

Independently of the type of food protein, the enzymatic hydrolysis process commonly comprises the following stages (Fig. 1): grinding the raw material and homogenization in water (or buffer), temperature equilibration and $\mathrm{pH}$ adjustment to the optimum values of the enzyme employed, followed by enzyme addition (García-Moreno et al., 2010). Recently, ultrasonicassisted hydrolysis was evaluated with the purpose of facilitating the production of low molecular weight peptides (Kadam et al., 2015). Upon completion of the reaction, the enzyme needs to be inactivated by heating or $\mathrm{pH}$ adjustment. Alternatively, continuous membrane reactor, where the enzyme is continuously recycled to the reaction tank, might also be used in order to stop the reaction and save enzyme costs (Prieto et al., 2010a). Subsequently, the digested material, which contains the

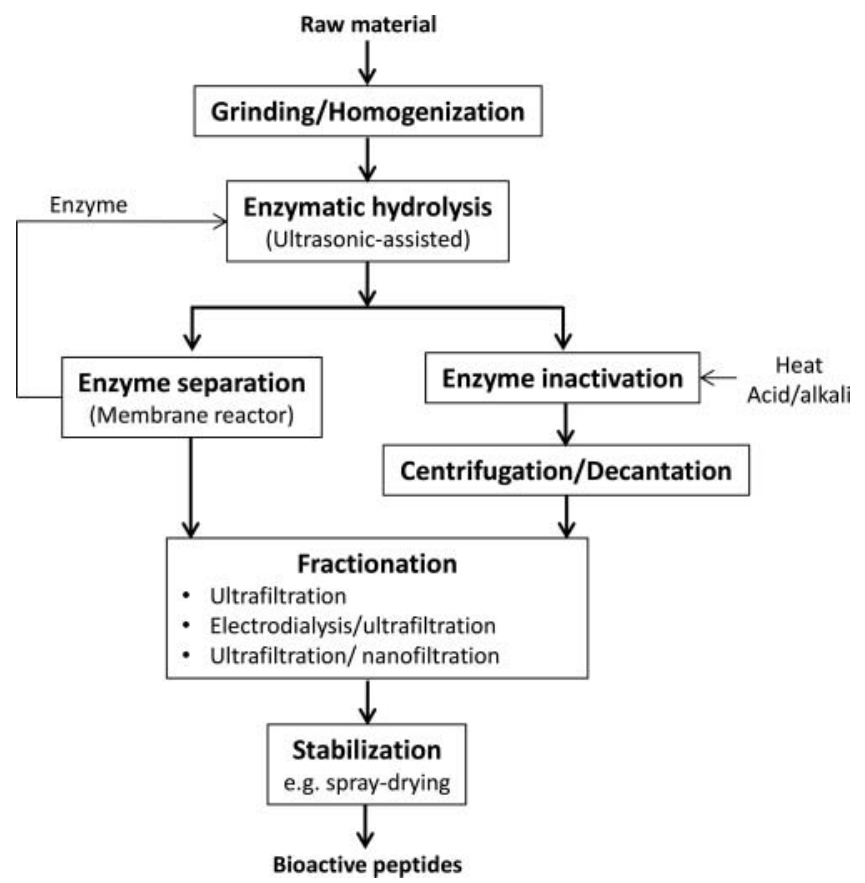

Figure 1. Flow diagram for the production of bioactive peptides.

bioactive peptides, is separated from the precipitate and lipids (e.g., centrifugation/decantation), fractionated, and further stabilized (e.g., by spray-drying) (Abdul-Hamid et al., 2002; Espejo-Carpio et al., 2014a).

Employing a proper enzyme and having good control over processing conditions (e.g., $\mathrm{pH}$, temperature, enzyme/protein ratio, and time) are critical aspects for the production of protein hydrolysates with the required properties (Kristinsson, 2006). Indeed, these process variables determine the extent of the hydrolysis reaction for a protein-enzyme system. This is normally indicated by the degree of hydrolysis $(\mathrm{DH})$, which is defined as the percentage of peptide bonds cleaved. There are several methods to determine the $\mathrm{DH}$ such as $\mathrm{pH}$-stat, trinitrobenzenesulfonic acid (TNBS), o-phthaldialdehyde (OPA), trichloroacetic acid soluble nitrogen (SN-TCA), and formol titration methods. Among them, the $\mathrm{pH}$-stat method is the most commonly employed since it allows maintaining the $\mathrm{pH}$ constant at the optimum of the enzyme and measuring the $\mathrm{DH}$ in real time (Rutherfurd, 2010). However, because this method is based on the titration of the proton released or consumed after the cleavage of the peptide bond, it is only suitable when the reaction is carried out under alkaline $(>7.5-7.8)$ or acidic $(<3.1-3.6) \mathrm{pH}$, respectively (Adler-Nissen, 1986). Another drawback of this method is the high salt content of the final hydrolysate as a consequence of the alkali or acid addition, which is required to maintain the $\mathrm{pH}$ constant and monitor the DH (Whitehurst and van Oort, 2009). As suggested by a recent study on whey protein, an interesting alternative could be to carry out the hydrolysis reaction without controlling $\mathrm{pH}$ (Le Maux et al., 2016). This work indicated that the bioactive properties of the hydrolysates (e.g., antioxidant and antidiabetic) might or might not be influenced by the control of the $\mathrm{pH}$, depending on the enzyme employed (e.g., papain or a microbial-derived alternative). 
In the enzymatic hydrolysis process, the specificity of the enzyme used is particularly important. This is because it affects size, amount, amino acid composition and amino acid sequence of the peptides produced, which in turn influences the bioactive and functional properties of the hydrolysates (Sarmadi and Ismail, 2010). Although crude proteases extracts (e.g., from fish) have been successfully used as catalysts in enzymatic hydrolysis (Bougatef et al., 2010; Lassoued et al., 2015b), commercially purified enzymes are preferably employed since they allow a better control over the hydrolysis process (e.g., shorter reaction time for a desired $\mathrm{DH}$, more consistent peptides size and composition) (Samaranayaka and Li-Chan, 2011). Consequently, industrial proteases derived from different sources such as microorganisms (e.g., Alcalase, Neutrase, Protease P "Amano" 6, Flavourzyme, Protamex) (Halldorsdottir et al., 2013; Venuste et al., 2013), animals (e.g., PTN, pepsin, trypsin, $\alpha$-chymotrypsin, pancreatin) (Wu et al., 2015a, b; García-Moreno et al., 2017) and plants (e.g., papain, bromelain) (Salampessy et al., 2015; Elavarasan et al., 2016) have been widely employed for the production of protein hydrolysates exhibiting bioactive and/or functional properties. These marketable proteases may mainly contain endopeptidases (e.g., trypsin, subtilisin, papain), or a combination of endopeptidases and exopeptidases (e.g., carboxypeptidases, aminopeptidases). Additionally, several enzymes can be utilized in the production of only one protein hydrolysate. Although they may be added simultaneously (Yamada et al., 2013; García-Moreno et al., 2017), sequential addition (e.g., after progressive decrease in the reaction rate) is normally carried out in order to achieve hydrolysates with a higher DH (Vaštag et al., 2011; GarcíaMoreno et al., 2014, 2015).

\section{Fermentation}

In addition to proteolysis through chemical digestion and/or addition of commercial enzymes to substrate, certain microbial strains secreting proteases can also be used to hydrolyze protein-rich substrates. The released peptides can have a high level of bioactivity with health-related benefits and better functional properties (Elfahri et al., 2016; Sanjukta and Rai, 2016; Rai et al., 2016).

The higher bioactivity of peptides from fermented products compared to the raw materials could be attributed to the change in amino acid composition in addition to size and sequence of the peptides. Xu et al. (2015) reported that the amounts of essential amino acids increased greatly following fermentation of soybean. Kleekayai et al. (2015) identified two ACE-inhibitory peptides (SV and IF) and one antioxidant peptide (WP) from fermented shrimp pastes. Pan et al. (2005) obtained two antihypertensive peptides with amino acid sequences of VPP and IPP from skimmed milk hydrolysate digested by cell-free extract of Lactobacillus helveticus. They proposed that the amino acid composition of the peptides accounts for bioactive effects of the fermented products.

Lactobacillus spp. is one of the most widely used genera for fermentation of protein-rich resources to release bioactive peptides. Upon the use of Lactobacillus, the foodstuff rapidly becomes acidified due to the production of lactic acid (Vallabha and Tiku, 2014). Production of lactic acid, which is an organic acid, may elongate the shelf life and render microbial safety and sensory quality to the final product (De Vuyst and Leroy, 2007). Besides, Lactobacillus can influence polypeptide quality by controlling cellular proteolysis. This is presumably done by degradation of protein into oligopeptides through their cellenvelope proteinase; cells absorb the oligopeptides via their peptide transport systems and transform them into shorter peptides and/or amino acids by intracellular peptidases (Savijoki et al., 2006). Lactic fermentation is useful not merely to attain bioactive peptides, but also to recover other components such as chitins, lipids, and minerals (López-Cervantes et al., 2006). Fermentation by lactic acid bacteria may also enhance organoleptic properties of final products (Aguirre et al., 2014). The efficiency of lactic acid bacteria in production of bioactive peptides can be related to their elaborate proteolytic system. It consists of a cell envelope proteinase, which initializes protein degradation, a transport system, and many intracellular peptidases (Pescuma et al., 2015).

Lactic fermentation has been adopted to attain bioactive peptides from milk resources such as antioxidant peptides from camel milk (El Hatmi et al., 2016), antioxidant, ACE inhibitory, antimicrobial, and immunomodulating peptides from whey $\beta$-lactoglobulin (Pescuma et al., 2015), and antimutagenic and anti-inflammatory peptides from $\beta$-casein (Espeche Turbay et al., 2012). In addition, Amadou et al. (2011) performed fractionation on the fermented soy protein meal hydrolysate by Lactobacillus plantarum and found that some fractions had great antioxidant activities. Jain and Kumar Anal (2017) produced functional and bioactive protein hydrolysates through fermentation of chicken eggshell membrane by using Lactobacillus plantarum. The resulting hydrolysates exhibited favorable functional properties with respect to solubility, foaming capacity, and emulsification activity as well as bioactivity in terms of DPPH-radical scavenging, reducing power, angiotensin-I converting enzyme inhibition, and protection against foodborne pathogens. Furthermore, Mechmeche et al. (2017) reported the production of bioactive peptides with antioxidant activity by using the fermentative strain Lactobacillus plantarum and tomato seed meal extract as the substrate.

Fermentation of protein resources have also been performed by using other genera of fermenting bacteria. Meinlschmidt et al. (2016) studied fermentation of soy protein isolate by Bacillus spp., Rhizopus spp., and Saccharomyces spp. in addition to Lactobacillus spp. and found that all fermented products were more soluble and had less off-flavor than nonfermented protein isolate. Moreover, Jemil et al. (2016) obtained antioxidant and ACE-inhibitory peptides (NVPVYEGY, ITALAPSTM, SLEAQAEKY, and GTEDELDKY) from sardinelle protein hydrolysates fermented by two species of Bacillus spp. namely B. subtilis and B. amyloliquefaciens. Furthermore, Jemil et al. (2014) prepared protein hydrolysate from sardinelle, zebra blenny, goby, and ray via fermentation by Bacillus subtilis and found that the hydrolysate had antioxidant and antimicrobial effects. Zhao et al. (2016a, b) produced protein hydrolysate from surimi through fermentation by Actinomucor elegans; they stated that the end product had a higher sensory acceptability compared to surimi before fermentation. Kumar Rai et al. (2017) produced protein hydrolysates rich in bioactive polyphenols by using three fermentative strains from Bacillus 
spp. namely B. subtilis KN12C, B. amyloliquefaciens KN2G, and $B$. licheniformis $\mathrm{KN} 13 \mathrm{C}$. They claimed that these strains possessed high protease, $\alpha$-amylase and $\beta$-glucosidase activities.

On the whole, fermentation is a promising method in order to prepare bioactive peptides from protein resources, especially those with limited consumption and/or from discarded sources. Lactobacillus spp. is the most prevalent genus to obtain bioactive peptides via fermentation although other genera such as Bacillus spp. are also used. Fermentation is prioritized over acid/base digestion since it does not cause the loss of essential amino acid and environmental pollution. It can also be an economical substitute for the use of efficient but expensive commercial enzymes.

\section{Removing bitterness}

Bitter taste is considered the most important barrier in commercial use of protein hydrolysates in food industry. Low molecular weight peptides account for the bitter taste of hydrolysates. These peptides are known to contain hydrophobic amino acids such as leucine, proline, phenylalanine, and tyrosine (Ishibashi et al., 1988; Meinlschmidt et al., 2016). In this regard, Aubes-Dufau et al. (1995) mentioned that the peptides with molecular weights up to roughly $6 \mathrm{kDa}$ and $\mathrm{Q}$ values exceeding $1400 \mathrm{cal} \cdot \mathrm{mol}^{-1} \mathrm{can}$ be considered bitter; $\mathrm{Q}$ value is a predictive index for bitterness of a given peptide and is defined as the hydrophobicity of the side chain of amino acids in the peptide (Ney, 1971). Bitterness of hydrolysates is not only caused by hydrophobic amino acid themselves but by their locations in peptide sequence, as well (Spellman et al., 2009). Hydrophobic amino acids caused more bitterness when they were inside the peptide chain rather than the $\mathrm{N}$ - or C-terminus of peptides (Matoba and Hata, 1972).

FitzGerald and O'Cuinn (2006) listed different methods of removing bitterness from protein hydrolysates: (i) absorption of bitter peptides on activated carbon; (ii) chromatographic removal using different matrices; (iii) selective extraction with alcohols; (iv) masking hydrolysates by addition of polyphosphates, specific amino acids such as Asp and Glu, and $\alpha$-cyclodextrins; (v) mixing hydrolysates with intact protein samples; (vi) formation of plasteins; and (vii) cross-linking using transglutaminase. However, they also pointed to drawbacks of these methods such as loss of some amino acid residues and decrease in solubility.

Recently, the formation of plasteins, which are less soluble aggregated macromolecular structures formed by incubation of higher concentrations of the hydrolyzed proteins or peptides with suitable proteases, has gained an increasing attention (Udenigwe and Rajendran, 2016). Plasteins were found to have lower bitterness than the peptides in hydrolysates (Liu et al., 2014). Proposed mechanisms of plastein formation include peptide condensation, transpeptidation, and physical forces in peptide aggregation (for more elaboration on the mechanisms, readers are referred to Gong et al., 2015). Plastein reaction was successfully adopted to reduce bitterness in the hydrolysates prepared from bovine red blood cells (Synowiecki et al., 1996) and yellowfin tuna (Zhao et al., 2015) as well as in synthetic dipeptides (Stevenson et al., 1998).
One of the most important factors influencing the taste of hydrolyzed protein is the sequence and nonpolarity of amino acids like F, W, Y, I, P, and H. Bitter taste perception of these amino acids can be changed by addition of $\alpha$-cyclodextrin to protein hydrolysate resulting in reduction of its bitterness (Linde et al., 2009). In addition, microencapsulation of hydrolysates plus incorporation of masking agents are effective alternatives for attenuation of bitterness in hydrolysates. Daskaya-Dikmen et al. (2017) claimed that encapsulation of peptides in hydrolysates is the most favorable technique in order to reduce bitterness. Favaro-Trindade et al. (2010) reported that bitter taste decreased when casein hydrolysates were spray-dried and mixed with gelatin and soy protein isolate as carriers. It is noteworthy that the debittering ability of gelatin might be attributed to its endogenous amino acid glycine to mask bitterness in hydrolysates (Stanley, 1981). Furthermore, Ma et al. (2013) compared freeze- and spray-drying of whey protein hydrolysates and found that the latter had higher efficiency of microencapsulation and therefore, resulted in less bitter hydrolysates.

The protease used to hydrolyze protein can also affect the taste of final product. Recently, Cheung et al. (2015) found that exopeptidase-treated hydrolysates are less bitter and have higher levels of umami and salty tastes as well as increased overall acceptability compared to those produced by endopeptidases. Moreover, when determing the influence of sequential hydrolysis using endo- and exo-peptidase on bitter taste of protein hydrolysates from wheat gluten, Liu et al. (2016) found that the hydrolysate produced within a 300-min reaction with Proteax had the lowest bitterness. Raksakulthai and Haard (2003) also indicated application of exopeptidases to reduce bitter taste of protein hydrolysate. Moreover, Nishiwaki et al. (2002) reported that an aminopeptidase from the edible basidiomycete Grifola frondosa can yield less bitter protein hydrolysates. However, Hou et al. (2011) claimed that all these procedures lead to a serious loss of essential amino acids. They suggested that using a combination of exo- and endopeptidases along with highpressure cooking can prevent the loss.

Besides, Newman et al. (2015) recommended the use of sweeteners and flavoring agents to reduce bitterness of protein hydrolysates. They added sucralose as a sweetener and vanilla as a flavoring agent to a model beverage containing sodium caseinate hydrolysate and concluded that this method was very effective in reducing the bitter taste of the beverage caused by the hydrolysate.

Although several methods have been proposed to reduce or remove bitterness from protein hydrolysates, the majority of them seemingly suffer from side effects like loss of amino acids and alteration of functional properties of the bioactive peptides obtained by the hydrolysis process. Besides, to the best of our knowledge, no study has been done to assess economic feasibility of the hitherto-proposed debittering solutions in industrial scale. Therefore, future studies should be directed towards finding the most effective and economical debittering methods with the least side effects in order to operationalize the adoption of bioactive peptides from hydrolyzed proteins in foodstuffs. 


\section{Fractionation, purification and identification of bioactive peptides including bioinformatics-driven approaches}

Fish protein hydrolysates are generally complex mixtures of peptides with different chain lengths and amino acids composition, as well as other nondesired compounds such as enzymes, nondegraded proteins and free amino acids. Hence, fractionation technologies are required to separate peptides from residual enzymes, and remaining nonreacted native proteins and free amino acids, which can induce allergenic responses and lead to osmotically-unbalanced products, respectively. Besides, the fractionation process makes it possible to control the molecular-weight distribution of the hydrolysates and to concentrate the desired bioactive or functional peptides (Akin et al., 2012). For that purpose, pressure-driven membrane techniques (e.g., ultrafiltration) are commonly used since they can easily be scaled-up (Langevin et al., 2012). Although most of the studies reported in the literature utilize polymeric membranes (Chabeaud et al., 2009; Jiang et al., 2010; Hwang et al., 2016), ceramic membranes are preferred at industrial scale due to their high chemical resistance, wider operational limits of $\mathrm{pH}$ and temperature, as well as extended operational lifetime (Lin et al., 2011; Espejo-Carpio et al., 2014b). In addition, tangential-flow filtration is recommended instead of cross-flow filtration membranes in order to limit membrane fouling (Prieto et al., 2010b).

Over the past few decades, due to the increasing interest in the production of natural biomolecules, there has been a boom in the number of publications dealing with the concentration of bioactive peptides by ultrafiltration. Generally, fractions containing low-molecular weight peptides have been reported to exhibit higher bioactivities in vitro. For instance, numerous studies indicate that peptide fractions $<1 \mathrm{kDa}$ showed the strongest Angiotensin-I converting enzyme (ACE)-inhibitory activity, independently of the type of raw protein (e.g., terrestrial plants or fish) (Zhao et al., 2007; Zou et al., 2014; Wu et al., 2016a, b). Nevertheless, these differences on ACE-inhibitory activity depending on the molecular weight of the peptides might not be observed in vivo as reported for salmon protein hydrolysate fractions (Ewart et al., 2009). As another example, low molecular weight peptides $(<1 \mathrm{kDa})$, obtained from the hydrolysis of whey protein isolate, have also been reported to exhibit a significant increase in the $\mathrm{Fe}^{2+}$ chelating activity when compared to larger peptide fractions (O'Loughlin et al., 2014). On the other hand, higher molecular weight peptides (1$3 \mathrm{kDa}$ ), obtained from hydrolysis of fish protein, were found to show the highest radical scavenging activity when compared to other peptide fractions $(<1,3-5$ and $5-10 \mathrm{kDa}$ ) (Kim et al., 2007).

Recently, more complex fractionation processes have been studied for the concentration of bioactive peptides. As an example, target bioactive peptides with similar molecular weight, which cannot be separated by pressure-driven membranes, have been concentrated by electrodialysis with ultrafiltration membranes (Doyen et al., 2014; He et al., 2016). Furthermore, sequential ultrafiltration and nanofiltration stages have also been tested in order to obtain even more concentrated peptide fractions with a reduced salt content (Langevin et al., 2012; Ranamukhaarachchi et al., 2013). In contrast, fractionation techniques are seldom applied to improve functional properties of protein hydrolysates. Among the few studies found in the literature, Jeon et al. (1999) reported that fractions from cod frames hydrolysates containing large peptides $(>30$ and $>10 \mathrm{kDa}$ ) showed excellent emulsifying properties and whippability. Likewise, Taheri et al. (2014) indicated that polypeptides $(>50 \mathrm{kDa}$ ) obtained from proteins contained in herring brine presented higher emulsion activity index, when compared to fractions having peptides with lower molecular weight. This indicates that only a limited hydrolysis of native proteins is required to improve these technological properties (e.g., emulsifying and foaming).

Further purification and identification of bioactive peptides are required in order to determine their structure-activity relationship. Initial peptide separation is normally performed by using fast protein liquid chromatography (FPLC), employing gel permeation or ion-exchange columns (Sampath Kumar et al., 2011; Vavrusova et al., 2015). The fraction containing the most active peptides is then subjected to high pressure liquid chromatography (HPLC) separation using a reverse-phase column (RP-HPLC). This allows obtaining peptides subfractions with different hydrophobic behavior, but more than one RPHPLC round will be required in order to obtain highly pure peptides in a sufficient amount (de Gobba et al., 2014a; Chi et al., 2015; Ruiz-Giménez et al., 2012). Furthermore, hydrophilic interaction liquid chromatography (HILIC) has recently been suggested for an improved separation of homologous short peptides (Le Maux et al., 2015). Finally, these chromatographic techniques are coupled to mass spectrometry (MS), in particular to tandem MS (MS/MS), for peptide sequence determination. Traditional identification approaches, which require the knowledge of the parent protein sequences, match tandem spectra with theoretical spectra derived from predicted peptides in a protein library (Espejo-Carpio et al., 2013; Gu and Wu, 2013; de Gobba et al., 2014b). Primary structure of proteins can be accessed from online databases such as UniProtKB/Swiss-Prot or NCBI and the identification process can be carried out by using database search engines (e.g., Mascot) (Dallas et al., 2015; Le-Maux et al., 2015). On the other hand, de novo sequencing approach does not require a protein library and deduces peptide amino acid sequence by calculating mass differences between fragments from the tandem mass spectra (Girgih et al., 2014; García-Moreno et al., 2015). For that purpose, generally employed programs are Peaks (Marques et al., 2015) and PepSeq (Liu et al., 2015). Alternatively to MS techniques, automated Edman degradation has been also widely employed for sequencing amino acids in a highly purified peptide (Je et al., 2005a; Sheih et al., 2009a, b; Chi et al., 2015).

Other advances in bioinformatics, also known as in silico analysis or software-based methods, allow predicting and identifying cryptic peptides likely to exhibit bioactivities, elucidate structure-function relationships and propose mechanisms of action (Li-Chan, 2015). BIOPEP, a database mainly focused on peptides from food, is generally employed to determine the occurrence frequency of embedded bioactive peptides in the primary structure of the food proteins of interest (Udenigwe, 2014; Lacroix and Li-Chan, 2012). Peptide cutter programs (e.g., ExPASy) are used to generate peptide profiles in silico 
from specific primary protein structures using enzymes of known specificity (Udenigwe et al., 2013; Nongonierma and FitzGerald, 2016a). Peptide cutters have been also employed to assay the potential cleavage by gastrointestinal tract enzymes of bioactive peptides obtained experimentally (Fitzgerald et al., 2012). Quantitative structure activity relationship models (QSAR) have been successfully used to predict biological activity of peptide sequences based on physicochemical descriptors (e.g., size, charge, polarity, sequence, etc.) (Sánchez-Rivera et al., 2014). For instance, QSAR approaches have been applied to study ACE-inhibitory, antioxidant and antimicrobial peptides (see Jahangiri et al., 2014; Nongonierma and Fitzgerald, 2016b). Finally, molecular docking simulations have also been developed to predict possible interactions of peptides with proteins (e.g., active sites of enzymes), which are the target of the biological activity (Li-Chan, 2015). Examples in the literature include studies on ACE as well as DPP-IV inhibitory peptides (Lin et al., 2017; Nongonierma et al. 2014). Thus, in silico tools may expedite the discovery and production of bioactive peptides from food proteins, although they still have some limitations (e.g., do not consider secondary, tertiary and quaternary structures of proteins to predict cleavage sites; and assume enzymes with stringent substrate specificity, which is not always the case in food applications where complex proteaseproteins interactions occur) (Li-Chan, 2015; Nongonierma and FitzGerald, 2016a; Udenigwe, 2014).

\section{Bioactivity of peptides}

\section{Effects on immune system}

An overview of reported effects on immune system is given in Table 1, which also shows the suggested peptides responsible for the effects.

\section{Antifungal effect}

Past few decades have witnessed a dramatic increase in fungal infections, especially the invasive ones with a high potential of claiming lives (Wang et al., 2016). Not only are they perilous for humans, they might have notorious influence on plants and may even kill them (Luna-Vital et al., 2015). Therapeutic options to fight against pathogen fungi seem to be very restricted since there are only few antifungals specialized for the pathogens (Wang et al., 2016). In addition, a global concern on the use of synthetic antifungals has directed academic efforts toward finding natural alternatives to combat against troublemaking fungi.

In nature, antifungal peptides are considered the first defense barrier between the organism and its surroundings. These peptides are small cationic and amphipathic molecules with not more than 50 amino acids (Shekh and Roy, 2012). Antifungal proteins and peptides have been isolated from different sources (Table 1).

\section{Antimicrobial effect}

Drug resistance in bacteria has turned out to be a major problem in using antibiotics in recent years. Add to this the current concern on using chemical preservatives in foods in order to avoid different kinds of spoilage including microbial decay. In this regard, one of the most interesting research breakthroughs is the discovery of the so-called antimicrobial peptides (AMPs) with a potential effect on even drug-resistant species (Tang et al., 2015). Production of AMPs can guarantee the innate immunity resistance against different pathogens. AMPs are majorly small cationic molecules and they are very favorable since their synthesis can be done with low metabolic cost and they have the capability to diffuse rapidly to the point of infection (Pisuttharachai et al., 2009). AMPs have a very wide scope in terms of their physiological roles, many of which are still to be determined. These roles range from killing microbes to modulating the immune system through increase in phagocytosis (Battison et al., 2008). It seems very important to find new resources from which the very promising alternatives for current antibiotics, i.e., AMPs, can be obtained.

Antimicrobial proteins and peptides have been obtained from a variety of sources such as aquatic organisms like shrimp (Cuthbertson et al., 2002), sole (Oren and Shai, 1996), flounder (Cole et al., 1997), and anchovy (Tang et al., 2015), plants (Capriotti et al., 2015), blood (Fogaca et al., 1999), milk (McCann et al., 2006), and egg (Mine et al., 2004), to name a few. One of the latest investigations to derive antimicrobial peptides from natural sources was the work performed by Capriotti et al. (2015). They identified antimicrobial peptides from soybean seeds and milk protein generated by simulated gastrointestinal digestion (Capriotti et al., 2015).

\section{Antiviral effect}

Bioactive peptides and hydrolysates were found to have antiviral activities against different species of viruses such as HSV-1 and HSV-2 (Conlon et al., 2014a). These peptides and hydrolysates were produced from different sources, e.g., oyster (Lee and Maruyama, 1998; Shimizu et al., 2009), crab (Miyata et al., 1989; Murakami et al., 1991; Masuda et al., 1992), mussel (Mitta et al., 2000), and even, different frog species skins (Conlon et al., 2014b). Antiviral effect of these peptides has been claimed to be in two ways: one through direct inactivation of virus particles and the other via interference in reproductive cycle of virus (Conlon et al., 2014a, b). Antiviral peptides from natural sources are especially appealing because they require a rather short contact time to induce their effect (Conlon et al., $2014 a, b)$.

\section{Immunomodulatory effect}

Proteins and peptides obtained from plant and animal sources (Table 1) have been found to improve lymphocyte proliferation, natural killer (NK), cell activity, antibody synthesis and cytokine regulation (Singh et al., 2014). Recently, milk bioactive peptides released by selected Lactobacillus helveticus strains (Elfahri et al., 2014) and the frog skin host-defense peptides (Mechkarska et al., 2014) were shown to induce stimulatory influence on the production of cytokines with pro- and antiinflammatory effects. In addition, an immunomodulatory peptide derived from zebrafish phosvitin has been suggested to upregulate the expression of the anti-inflammatory and downregulate the expression of the pro-inflammatory cytokine genes (Ding et al., 2012).

Parker et al. (1984) detected a hexapeptide with amino acid sequence of VEPIPY with immunostimulatory effect. The 
Table 1. Effects of bioactive peptides on immune system.

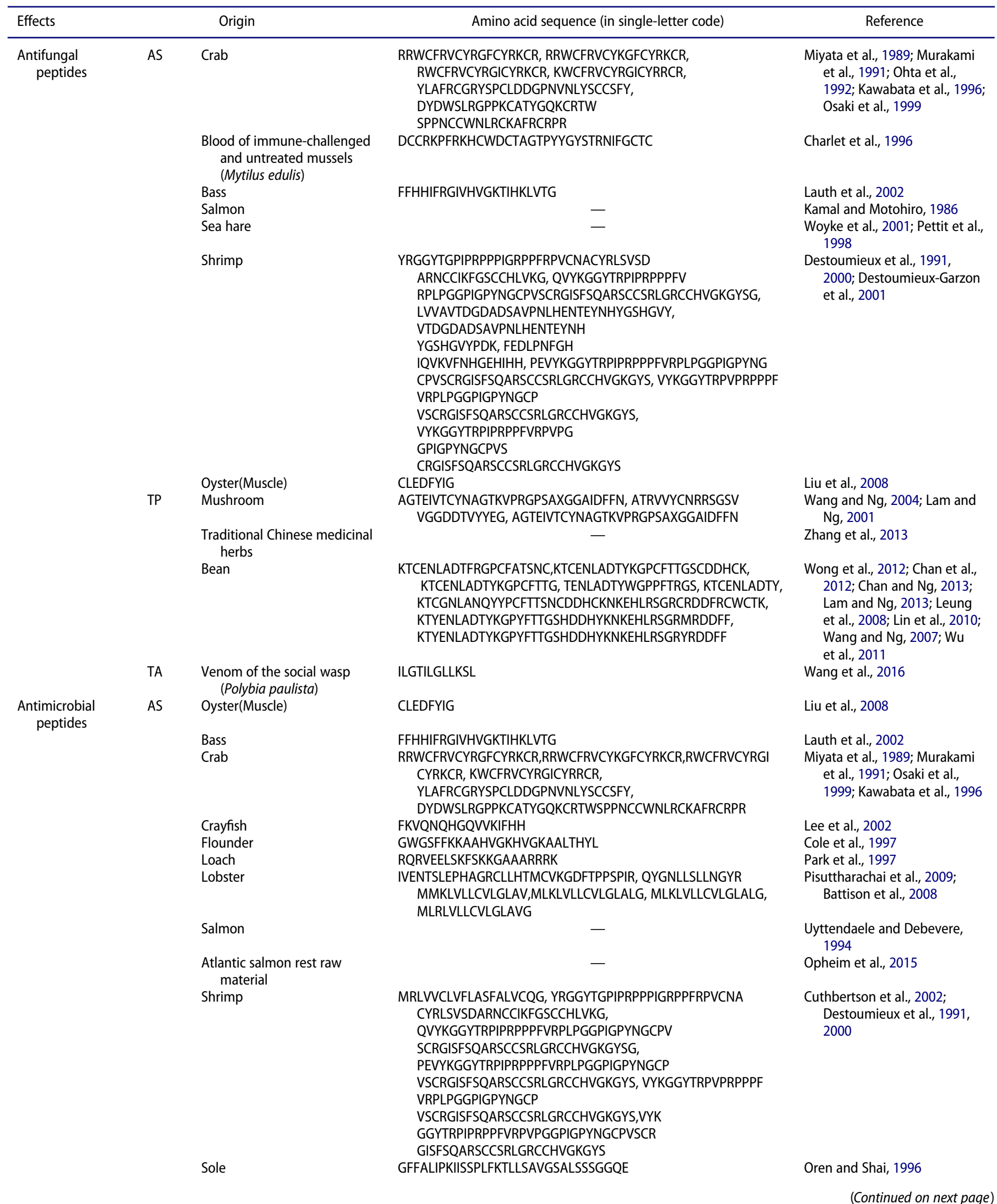


Table 1. (Continued)

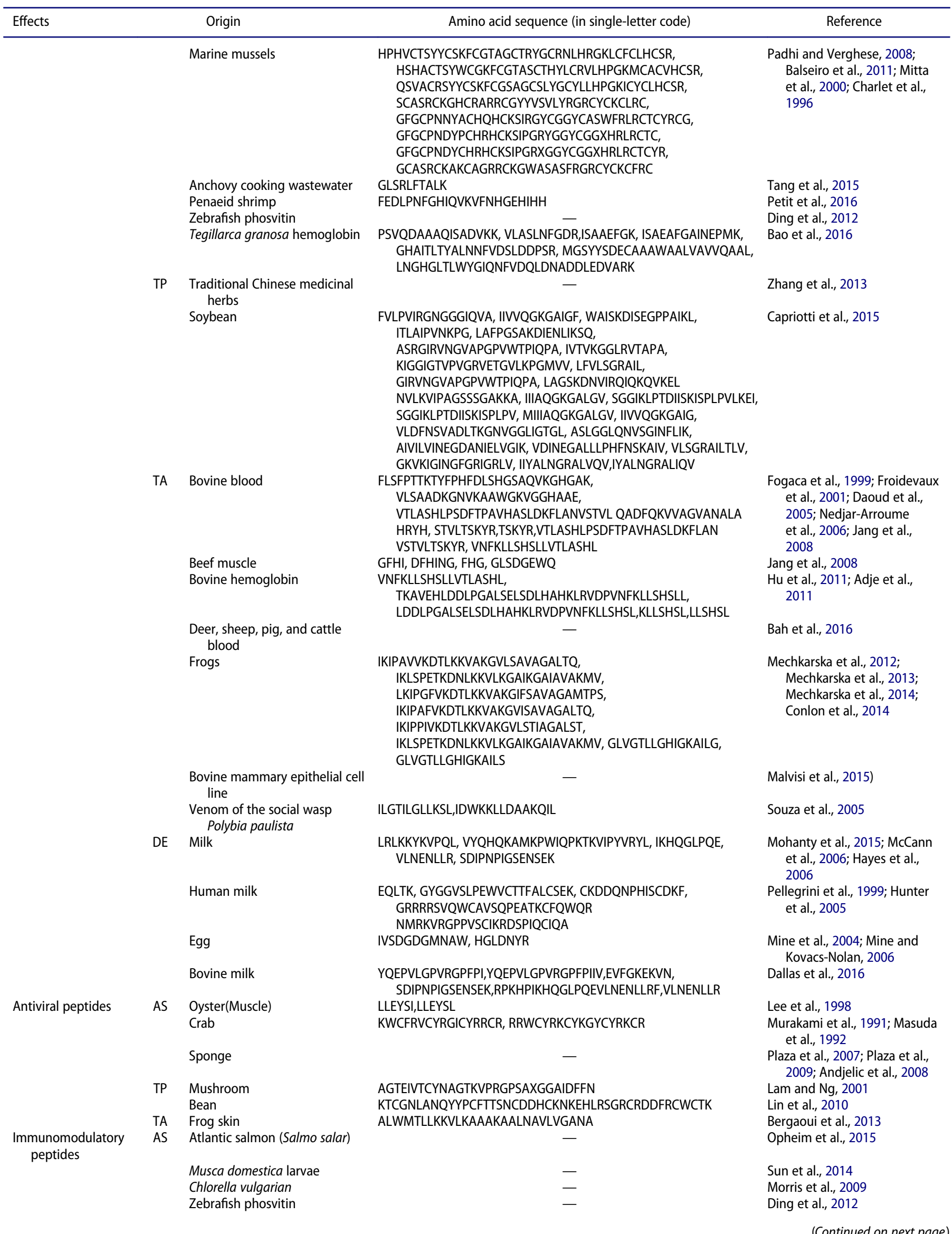


Table 1. (Continued)

\begin{tabular}{|c|c|c|c|c|}
\hline Effects & & Origin & Amino acid sequence (in single-letter code) & Reference \\
\hline & \multirow[t]{7}{*}{$\mathrm{TP}$} & Soybean & $\begin{array}{l}\text { MITLAIPVNKPGR, MITLAIPVN, MITL, HCQRPR, } \\
\text { QRPR, MITLAIPVNKPGR }\end{array}$ & $\begin{array}{l}\text { Yoshikawa et al., 2000; Singh } \\
\text { et al., 2014; Capriotti et al., } \\
2015\end{array}$ \\
\hline & & Rice & GYPMYPLPR & Takahashi et al., 1994 \\
\hline & & Mushroom & - & $\begin{array}{l}\text { Sheu et al., 2004; Lin et al., } \\
2013\end{array}$ \\
\hline & & Wheat & - & Horiguchi et al., 2005 \\
\hline & & Buckwheat pollen & RKYVD & Liu et al., 1998 \\
\hline & & Turmeric (Curcuma longa) & - & Aravind and Krishnan, 2016 \\
\hline & & Chickpea & - & Clemente et al., 1999 \\
\hline & \multirow[t]{2}{*}{ TA } & Frog skin & $\begin{array}{l}\text { GLVGTLLGHIGKAILG, GLVGTLLGHIGKAILS, IKLSPE } \\
\text { TKDNLKKVLKGAIKGAIAVAKMV }\end{array}$ & $\begin{array}{l}\text { Mechkarska et al., 2014; } \\
\text { Conlon et al., 2014; } \\
\text { Mechkarska et al., } 2013\end{array}$ \\
\hline & & $\begin{array}{l}\text { Bovine mammary epithelial cell } \\
\quad \text { line }\end{array}$ & - & Malvisi et al., 2015 \\
\hline & \multirow[t]{8}{*}{ DE } & Egg & - & Xie et al., 2002; Fan et al., 2003 \\
\hline & & Milk & TTMPLW, YPFPAVPYPQRTTMPLW, YQEPVLGPVR, LLY & $\begin{array}{l}\text { Meisel, 2005; Mohanty et al., } \\
\text { 2015; Elfahri et al., 2014; } \\
\text { Hernandez-Ledesma et al., } \\
\text { 2004; Berthou et al., } 1987\end{array}$ \\
\hline & & Camel milk & QEPVPDPVRGLHP & El Hatmi et al., 2016 \\
\hline & & Whey & - & Mercier et al., 2004 \\
\hline & & Bovine milk & PGPIPN, YQEPVLGPVRGPFPIIV, PGPIPN, LYQEPVLGPVRGPFPIIV & $\begin{array}{l}\text { Boutrou et al., 2013; Dallas } \\
\text { et al., } 2016\end{array}$ \\
\hline & & Bursa of Fabricius (BF) in chicken & YEYAY, RMYEE, GPPAT, AGCCNG, RRL & Feng et al., 2012 \\
\hline & & Human milk & VEPIPY & Parker et al., 1984 \\
\hline & & Egg & SVNVHSSL,YRGGLEPIN & Goldberg et al., 2003 \\
\hline \multirow[t]{3}{*}{$\begin{array}{l}\text { Cytomodulatory } \\
\text { peptides }\end{array}$} & \multirow[t]{3}{*}{$\mathrm{DE}$} & Bovine milk & $\begin{array}{l}\text { KAVPYPQ,PYPQ, RTLGYLE,RTLGYL, YPFPGPI YVPFPYPFPG, AVP } \\
\text { YPQR,RETIESLSSSEESIPEYK, QPTIPFFDPQIPK }\end{array}$ & $\begin{array}{l}\text { Kampa et al., 1997; Nagaune } \\
\text { et al., 1989; Hernandez- } \\
\text { Ledesma et al., } 2004\end{array}$ \\
\hline & & Camel milk & KRKEMPLLQSPV & El Hatmi et al., 2016 \\
\hline & & Casein & EPVLGPVRGP & Zhao et al., 2014 \\
\hline \multirow[t]{17}{*}{$\begin{array}{l}\text { Antiproliferative, } \\
\text { anti-tumor, and } \\
\text { anti-cancer } \\
\text { peptides }\end{array}$} & \multirow[t]{5}{*}{$\mathrm{TP}$} & Bean (Phaseolus vulgaris L.) & $\begin{array}{l}\text { KTYENLADTYKGPYF } \\
\text { TTGSHDDHYKNKEHLRSGRMRDDFF, } \\
\text { KTCGNLANQYYTPCFTSNCDDHCKNKEHLRSGRCRDDFRCWCT } \\
\text { K, KTYENLADTYKGPYFTTGSHDDHYKNKEHLRSGRYRDDFF }\end{array}$ & $\begin{array}{l}\text { Wang and Ng, 2007; Lin et al., } \\
\text { 2010; Wu et al., } 2011\end{array}$ \\
\hline & & Mushroom Flammulina velutipes & - & Lin et al., 2013 \\
\hline & & Soybean & $\begin{array}{l}\text { XMLPSYSPY, SKWQHQQDSCRKQKQGV } \\
\text { NLTPCEKHIMEKIQGRGDDDDDDDDD }\end{array}$ & $\begin{array}{l}\text { Kim et al., 2000; Valjakka et al., } \\
1997\end{array}$ \\
\hline & & Turmeric (Curcuma longa) & - & Aravind and Krishnan, 2016 \\
\hline & & Bean & KTCGNLANQYYPCFTTSNCDDHCKNKEHLRSGRCRDDFRCWCTK & Lin et al., 2010 \\
\hline & $\mathrm{TA}$ & Frog skin & $\begin{array}{l}\text { IKLSPETKDNLKKVLKGAIKGAIVAKMV, } \\
\text { GLWSKIKEAAKAAGKAALNAVTGLVNQGDQPS, GLVG } \\
\text { TLLGHIGKAILG,GLVGTLLGHIGKAILS }\end{array}$ & $\begin{array}{l}\text { Attoub et al., 2013; Conlon } \\
\text { et al., 2007; Mechkarska } \\
\text { et al., 2014; Conlon et al., } \\
2014\end{array}$ \\
\hline & \multirow[t]{10}{*}{ AS } & Sea hare (Dolabella auricularia) & $\mathrm{XVXXX}$ & $\begin{array}{l}\text { Madden et al., 2000; Pettit } \\
\text { et al., 1998; Turner et al., } \\
\text { 1998; Vaishampayan et al., } \\
2000\end{array}$ \\
\hline & & Musca domestica larvae & - & Sun et al., 2014 \\
\hline & & Fish sauce & - & Lee et al., 2003, 2004 \\
\hline & & Sea hare (Dolabella auricularia) & \multirow[t]{2}{*}{ XVXXX } & Madden et al., 2000 \\
\hline & & Cod, plaice, salmon & & $\begin{array}{l}\text { Xhindoli et al., 2016; Ngo et al., } \\
2012\end{array}$ \\
\hline & & Tuna muscle & \multirow[t]{2}{*}{ LPHVLTPEAGAT, PTAEGGVYMVT } & Hsu et al., 2011 \\
\hline & & Fish backbone & & $\begin{array}{l}\text { Zhang et al., 2013; Ngo et al., } \\
\qquad 2012\end{array}$ \\
\hline & & Sardine muscle & \multirow[t]{3}{*}{ VY } & Matsui et al., 2005 \\
\hline & & Shrimp shell & & Kannan et al., 2011 \\
\hline & & $\begin{array}{l}\text { Sea slug (Pleurobranchus } \\
\text { forskalii) }\end{array}$ & & Wesson and Hamann, 1996 \\
\hline & $\mathrm{DE}$ & Bovine Milk & $\begin{array}{l}\text { VENLHLPLPLL,NLHLPLPLL, ENLHLPLPLL, ALNENLLRFFVAPFP } \\
\text { EVFG, LNENLLRFFVAPFPEVFG, NENLLRFFVAPFPEVFG, } \\
\text { ENLLRFFVAPFPEVFG, FVAPFPEVFG }\end{array}$ & Juillerat-Jeanneret et al., 2011 \\
\hline \multirow{3}{*}{$\begin{array}{l}\text { Antimutagenic and } \\
\text { antigenotoxic }\end{array}$} & $\mathrm{DE}$ & Kefir & - & Guzel-Seydim et al., 2011 \\
\hline & $\mathrm{TA}$ & $\begin{array}{l}\text { Bovine plasma, globulin and } \\
\text { albumin }\end{array}$ & - & Park and Hyun, 2002 \\
\hline & & Silk fibroin & - & Park et al., 2002 \\
\hline
\end{tabular}

$A S, T P, T A$, and DE stand for aquatic sources, terrestrial plants, terrestrial animals, and dairy \& eggs, respectively. Uncommon amino acids are denoted by "X." 
peptide was claimed to stimulate in vitro phagocytosis of sheep red blood cells by murine macrophages and to have in vivo protective effect in mice against lethal infection caused by Klebsiella pneumonia (Parker et al., 1984).

On the other hand, application of bioactive peptides from different resources has been limited due to their potential antigenicity and immunoreactivity in the body. In this regard, protein hydrolysates with hypoimmunoreactive effect are more favorable to be used in industrial products. Clemente et al. (1999) obtained extremely hypoimmunoreactive protein hydrolysates from chickpea by sequential treatment using endo- and exopeptidases. They defined hypoimmunoreactivity by the loss of antigenicity through reduction in the interaction capacity of antigenic determinants with specific antibodies (Clemente et al., 1999).

\section{Cytomodulatory effect}

Bioactive peptides obtained from different sources (Table 1) have been shown to have cytomodulatory effect. Zhao et al. (2014) identified peptides from casein with cytomodulatory effect (Zhao et al., 2014). Cytomodulation can be of a great health importance since it is related to cell proliferation and apoptosis as two attributes of cell viability (Zhao et al., 2014). These peptides can also regulate immune cells and therefore, they can play an important role in regulation of immune system (Elfahri et al., 2014). However, the term cytomodulation seems to include a wide spectrum of applications with key roles in controlling cancer, tumor, and other cell-related disorders. In other words, there is seemingly some conceptual overlap between immunomodulation, cytomodulation, anticancer, antitumor, etc. Nonetheless, we present a separate part as follows to give a better overview of peptide bioactivity.

\section{Antiproliferative/antitumor/anticancer effects}

Cancer is one of the most important diseases in the world and millions of people die annually as a consequence of this dangerous disorder. It is generally characterized by the presence of transformed cells in different tissues. In other words, the carcinogenic cells start out-of-control multiplication in the site they belong to without rendering the role they are originally supposed to. The transformed invasive cells can even cross through their own sites and enter, say, blood vein to cause more severe problems (Luna-Vital et al., 2015). There are several chemotherapeutics and targeted antineoplastic agents commercially available; however, although they prove to be very efficient against tumor and cancer, there have also been serious complaints regarding their adverse side-effects. In addition, resistance to chemotherapy-based treatments has also increased concerns regarding cancer cure since some patients experience tumor relapse with the new tumor being resistant to alreadyadopted treatments (Sun et al., 2014). Taken together, academic interest has shifted toward finding dietary agents in order to block or at least alleviate the effects of tumor or even to prevent outbreak of cancer. Bioactive peptides from different sources have been found to have antitumor effects (Attoub et al., 2013; Lin et al., 2013; Sun et al., 2014; Luna-Vital et al., 2015) (Table 1). Yet, no single mechanism has been detected for the peptides to cause tumor cell death, but their action mechanism includes nonspecific perturbation of the cell membrane and subsequent insertion into the lipid bilayer so as to disrupt cell membrane (Attoub et al., 2013).

Bioactive peptides from natural resources have also been found to fight against proliferation of trouble-making cells. Several studies have shown that peptides from different sources such as sea hare (Pettit et al., 1998; Turner et al., 1998; Madden et al., 2000; Vaishampayan et al., 2000; Woyke et al., 2001), fish sauce (Thang and Zhao, 2015; Bah et al., 2016), and cod (Xhindoli et al., 2016) were able to block proliferation of carcinogenic cells. However, it seems there is still a long way in order to make commercial use of these potentially potent anticancer peptides to treat different kinds of cancer. For example, clinical intervention trials are needed to fully document the effects.

\section{Antigenotoxic and antimutagenic effects}

There might be confusion in defining genotoxicity and mutagenicity. In general, genotoxicity is defined as the potential of a chemical agent to impair genetic information within a cell; such impairment might cause mutation (mutagenicity) and cancer. In other words, genotoxics include a broader spectrum of harmful agents than mutagens; simply put, although all mutagens can be considered genotoxic agents, not all genotoxics are mutagens. Therefore, it is important to find substances in order to shield DNA from possible damage. Park et al. (2002) compared antigenotoxic properties of acidic and enzymatic hydrolysates produced from silk fibroin. They analyzed antigenotoxicity of the isolates in mouse embryo 3T3 cells via Comet assay and concluded that acidic-derived isolates showed higher antigenotoxic activity than those synthetized by the commercial enzyme. Furthermore, they claimed that the treatment containing $10 \mathrm{mg} / \mathrm{ml}$ acidic isolates would provide 87 percent protection from DNA damage. They proposed two possible circumstances for antigenotoxicity of the isolates: first, protective interactions between cells and peptide molecules and second, the direct role of peptides to inactivate the mutagen (Park et al., 2002).

\section{Effects on cardiovascular system}

Table 2 provides an overview of reported effects of peptides on the cardiovascular system.

\section{Antithrombotic activities}

Blood coagulation is a natural and important process required to survive. The process is carried out in abnormal vascular conditions or absence of endothelial surface in the case of vascular injury (Jung and Kim, 2009). However, blood coagulation and clot formation are considered undesirable circumstances in some medical conditions and therefore, antithrombotic agents, especially natural ones, are favored. In this regard, bioactive peptides have been found to have antithrombotic effect (Jolles et al., 1986; Raha et al., 1988; Mazoyer et al., 1990; Chabance et al., 1995; Morimatsu et al., 1996; Shimizu et al., 2009). There are two types of antithrombotic agents: anticoagulants and antiplatelets. The former prevent the formation and growth of clots while the latter inhibit platelet clumping (Li-Chan et al., 2016).

Exogenous anticoagulants from natural sources can be adopted to prolong or stop blood clotting (Jo et al., 2008). This 
CRITICAL REVIEWS IN FOOD SCIENCE AND NUTRITION

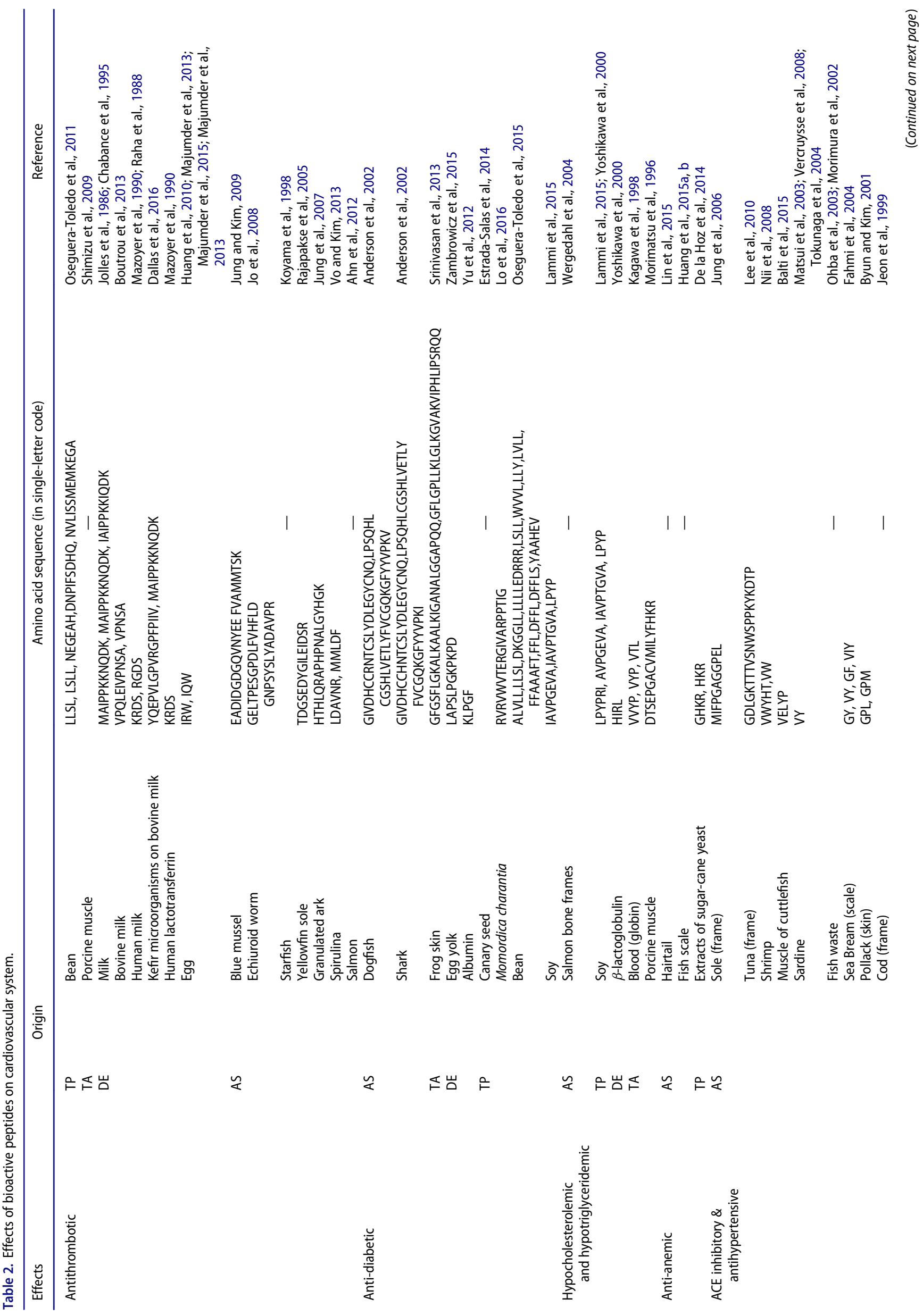







CRITICAL REVIEWS IN FOOD SCIENCE AND NUTRITION
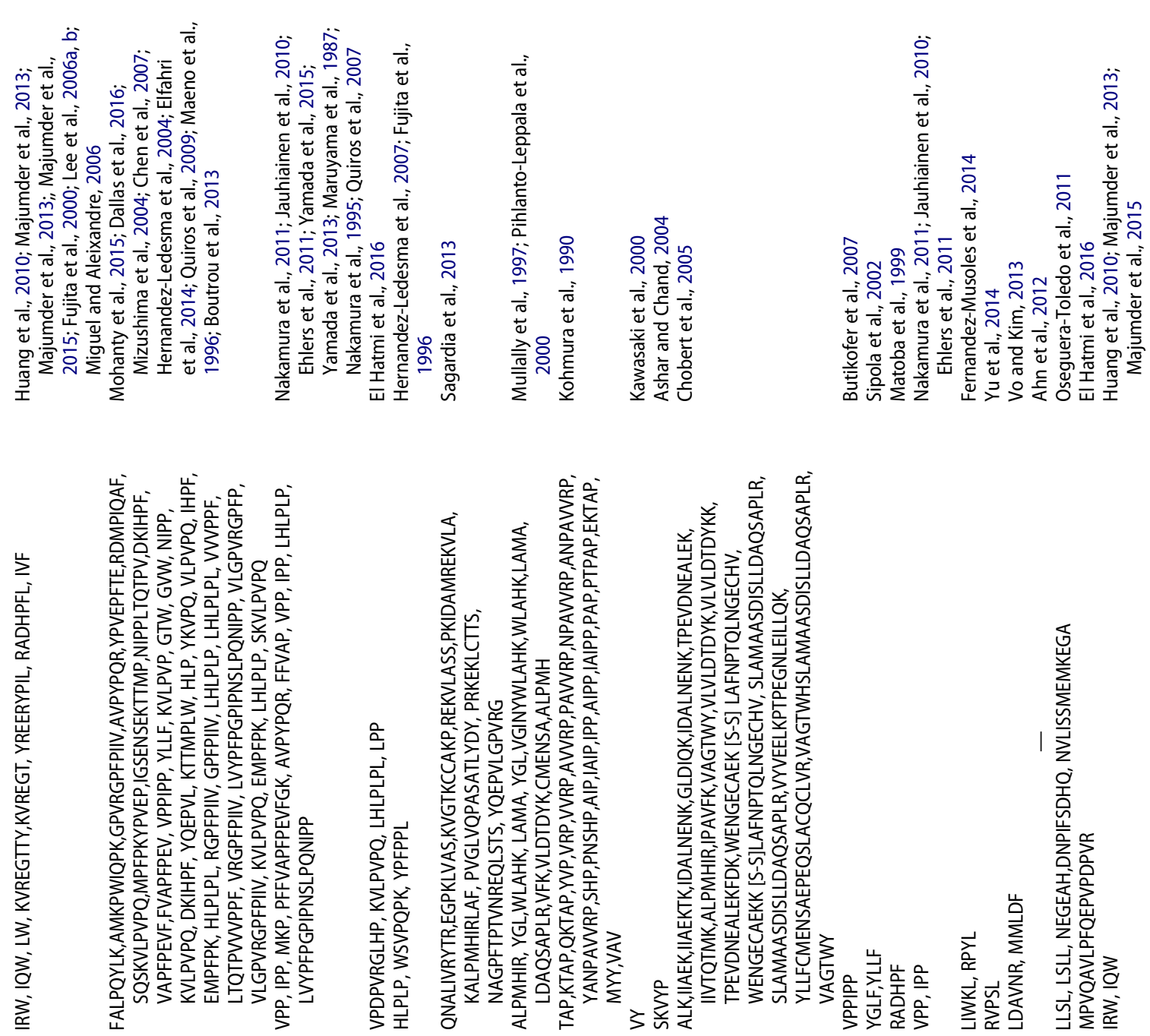



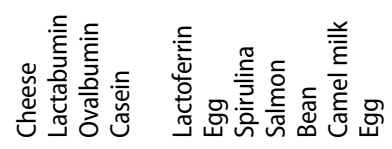

㟔

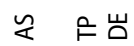


comes in handy in a few clinical situations and hematological studies (Koyama et al., 1998). Anticoagulants are predominantly important in prevention of ischemic events in patients with cardiovascular diseases (Rajapakse et al., 2005). Bioactive peptides, especially from marine resources, have been found to have anticoagulant activities (Koyama et al., 1998; Rajapakse et al., 2005; Jung et al., 2007; Jo et al., 2008; Jung and Kim, 2007, 2009). Antiplatelet peptides have also been found from natural resources; these peptides render their effect through inhibition of ADP-induced platelet aggregation and fibrinogen binding (Chabance et al., 1998).

\section{Anti-diabetic effect}

Diabetes mellitus (DM) is a very prevalent disease worldwide with higher level of outbreak in low- and middle-income nations. It is surmised that DM will affect 438 million people by 2030 (Yu et al., 2012). Therefore, scientific studies have been directed toward finding effective but cheaper solutions to cope with the problem. Bioactive peptides have been shown to exert anti-diabetic effect mainly through two ways: (1) insulin release (Srinivasan et al., 2013; Oseguera-Toledo et al., 2015); and (2) activity against $\alpha$-glucosidase (Yu et al., 2012; Oseguera-Toledo et al., 2015; Zambrowicz et al., 2015), $\alpha$-amylase (Yu et al., 2012; Oseguera-Toledo et al., 2015), and Dipeptidyl peptidase4 (DPP-IV) (Oseguera-Toledo et al., 2015; Zambrowicz et al., 2015).

Srinivasan et al. (2013) found ten peptides from skin secretions of the tetraploid clawed frog Xenopus laevis with stimulatory effect on insulin release from the rat BRIN-BD11 clonal $\beta$ cell line. They mentioned two peptides (CPF-7 and CPF-SE1; refer to Table 2 for their amino acid sequences) as the most potent stimulators of insulin release from the cell line (Srinivasan et al., 2013).

$\mathrm{Yu}$ et al. (2012) identified eight peptides from albumin with activity against $\alpha$-glucosidase and $\alpha$-amylase. They further reported that one of the peptides, KLPGF, had the highest effect against $\alpha$-glucosidase and $\alpha$-amylase with $\mathrm{IC}_{50}$ values of $59.5 \pm$ 5.7 and $120 \pm 4.0 \mu \mathrm{mol} \cdot \mathrm{l}^{-1}$, respectively (Yu et al., 2012). Moreover, Zambrowicz et al. (2015) reported high level of anti-diabetic effects of bioactive peptides in a by-product of phospholipid extraction from egg yolk through inhibition of $\alpha$-glucosidase and DPP-IV. They claimed that a peptide from the by-product, with amino acid sequence of LAPSLPGKPKPD, showed the strongest $\alpha$-glucosidase inhibitory $\left(1065.5 \mu \mathrm{mol} \cdot \mathrm{l}^{-1}\right)$ and DPP-IV inhibitory $\left(361.5 \mu \mathrm{mol} \cdot \mathrm{l}^{-1}\right)$ activities (Zambrowicz et al., 2015).

Furthermore, three peptides from soy glycinin, with amino acid sequences IAVPGEVA, IAVPTGVA, and LPYP, were found to increase glucose uptake in human hepatic HepG2 cells. This effect was claimed to be via the stimulation of protein kinase $\mathrm{B}$ and adenosine monophosphate-activated protein kinase pathways stimulated by activation of two glucose transporters, i.e., GLUT1 and GLUT4 (Lammi et al., 2015).

\section{Hypocholesterolemic and hypotriglyceridemic effects}

Blood lipid profile was shown to be associated with bioactive peptides from different resources. In a study on the effect of fish protein hydrolysates prepared from flesh remnants on salmon bone frames after filleting, Wergedahl et al. (2004) found that fish protein hydrolysate (FPH) reduced plasma concentration of cholesterol in a hyperlipidemic animal model, i.e., the obese Zucker rat. They explained that this effect could not be through the excretion of fecal bile acids since dietary FPH did not affect the fecal bile acid; instead, they suggested that this effect of FPH could be by increasing hepatic activity of 3hydroxy-3-methylglutaryl-coenzyme A (HMG-CoA) reductase. They also associated cholesterol regulatory effect of FPH to significant reduction of Acyl-CoA cholesterol acyltransferase (ACAT) activity (Wergedahl et al., 2004). A significant reduction of the plasma cholesterol concentration, especially the VLDL and LDL cholesterol concentrations, was also reported in rats fed a cholesterol-enriched diet by using papain-hydrolyzed pork meat (Morimatsu et al., 1996).

On the other hand, Kagawa et al. (1998) stated that reduction in serum triglycerides is even more important than decrease in serum cholesterol to prevent cardiovascular disease. The authors found a bioactive peptide, VVYP, from globin digest with a capability to rapidly clear dietary hypertriglyceridemia by inhibition of fat absorption from digestive tract and increased activity of hepatic triglyceride lipase (HTGL) (Kagawa et al., 1998).

\section{Anti-anemic effect}

Anemia can be caused by iron deficiency and therefore, chelating agents with ability of enhancing iron bioavailability can decrease the level of anemia. Lin et al. (2015) studied anti-anemic activity of protein hydrolysate prepared by enzymatic hydrolysis of beheaded and eviscerated hairtail in male Wistar rats and found that the hydrolysate could be regarded as a potential iron-delivery and anti-anemic source with no major disturbance in natural microbiome and gastrointestinal mucosa (Lin et al., 2015).

Furthermore, de la Hoz et al. (2014) revealed that enzymatic hydrolysis of the extract of sugar-cane yeast (Saccharomyces cerevisiae) by Viscozyme yielded iron-binding peptides, which increased iron bioavailability. They analyzed iron bioavailability through the iron dialyzability (i.e., the amount of soluble and stable iron until intestinal digestion) during in vitro digestion. They further isolated the peptides through immobilized metal affinity chromatography (IMAC) and showed that His, Lys, and Arg were more prevalent in these anti-anemic peptides (De la Hoz et al., 2014).

\section{ACE inhibitory and antihypertensive effect}

Hypertension is regarded as an important chronic health problem in epidemic proportions. It is considered a high risk factor for such complications as arteriosclerosis, stroke, myocardial infarction and end-stage renal disease (Jung et al., 2006).

One of the most considerable instruments in mammals in order to keep blood pressure homeostasis and fluid and salt balance is renin-angiotensin system. Angiotensin I converting enzyme (ACE) is a key factor in the mentioned system to regulate blood pressure. In other words, inhibition of this enzyme is very applicable method to control hypertension (Lee et al., 2010). ACE renders its effect by catalyzing formation of angiotensin II which is a vasoconstrictor (Nii et al., 2008). Synthetic inhibitors, such as captopril, enalapril, alacepril and lisinopril, are commercially available but their use is restricted due to 
their possible adverse effects including cough, taste disturbances, and skin rashes (Lee et al., 2010). Therefore, special attention has been given to ACE inhibitory effects of nutraceuticals from bio-resources. Bioactive peptides from natural resources have been found to have a high level of ACE-inhibitory and antihypertensive effects (Je et al., 2005a, b, c; Jung et al., 2006; Nii et al., 2008; Lee et al., 2010; Yamamoto, 2010; Adje et al., 2011; Norris and FitzGerald, 2013; Singh et al., 2014; Mohanty et al., 2015; Capriotti et al., 2015; Esteve et al., 2015; El Hatmi et al., 2016). These peptides are very valuable because they have variety of functions and they are easily absorbed in the body and therefore, they can potentially be considered a great alternative for the synthetic antihypertensive drugs (Lee et al., 2010). Although a huge body of research has been dedicated to antihypertensive effect of bioactive peptides from plant (Motoi and Kodama, 2003; Chen et al., 2003; Motoi and Kodama, 2003; Nakano et al., 2006; Kodera and Nio, 2006; Kodera and Nio, 2006; Lee et al., 2006a, b; Zhu et al., 2006; OsegueraToledo et al., 2011; González-García et al., 2014; OsegueraToledo et al., 2015; Capriotti et al., 2015; Esteve et al., 2015; Coscueta et al., 2016; Da Silva Vaz et al., 2016), terrestrial animals (Morimatsu et al., 1996; Arihara et al., 2001; Nakashima et al., 2002; Saiga et al., 2003; Vercruysse et al., 2005; Arihara, 2006; Yu et al., 2006; Sentandreu and Toldra, 2007; Li et al., 2007; Chang et al., 2007; Wang et al., 2008a; Xu et al., 2009; Shimizu et al., 2009; Kim et al., 2009; Liu et al., 2010; Bernardini et al., 2012; Escudero et al., 2013), seafood (Jeon et al., 1999; Byun and Kim, 2001; Morimura et al., 2002; Ohba et al., 2003; Fahmi et al., 2004; Je et al., 2005; Je et al., 2005; Nagai et al., 2006; Hai-Lun et al., 2006; Padhi and Verghese, 2008; Wang et al., 2008b; Tsai et al., 2008; Nii et al., 2008; Lee et al., 2010; Lee et al., 2010), and dairy (Hernandez-Ledesma et al., 2004; Chen et al., 2007; Sagardia et al., 2013; Elfahri et al., 2014; Wada and Lönnerdal, 2014; Mohanty et al., 2015; Coscueta et al., 2016) products among others, serious efforts have not been allocated to make commercial use of these potentially potent antihypertensive peptides in developing countries. This may be due to various factors such as technological barriers, economic issues, lack of public awareness about the antihypertensive peptides, to name a few.

\section{Anti-inflammatory effect}

When the body is exposed to pathogen attacks or tissue injury caused by biological, chemical, and/or physical factors, inflammation occurs as a natural defensive mechanism. In this regard, macrophage-released inflammatory mediators such as nitric oxide (NO) and proinflammatory cytokines such as tumor necrosis factor- $\alpha$ (TNF- $\alpha$ ), interleukin-6, and $-1 \beta$ play pivotal roles to initiate defense reactions. However, overproduction of these inflammatory mediators can cause several ailments such as rheumatoid arthritis, asthma, atherosclerosis, and endotoxin induced multiple organ injury in humans (Ahn et al., 2012).

Bioactive peptides from different resources have been able to block inflammation (Nagaune et al., 1989; Huang et al., 2010; Ahn et al., 2012; Majumder et al., 2013a, b, 2015; Vo and Kim, 2013). This is very important because authors have recently warned about possible negative effects of synthetic drugs and therefore, foodstuffs with potential anti-inflammatory effects are in the first row of attention.
It is noteworthy that NO is regarded as an important signaling molecule in vasodilation, neurotransmission, and host immune defense (Ahn et al., 2012) and peptides from whey protein (Ballard et al., 2009), A $\alpha$-lactabumin and A $\beta$-lactabumin (Sipola et al., 2002), ovalbumin (Matoba et al., 1999), flaxseed protein (Udenigwe and Aluko, 2012), skeletal muscle protein (Takahashi et al., 2009), and even human casein (Fujita et al., 1996) were found to enhance NO production.

\section{Effects on nervous system}

An overview of reported effects of peptides on nervous system is given in Table 3.

\section{Opioid and antinociceptive}

Pharmacological management of various types of pain has gained a strong attention in recent years (Brantl et al., 1985). Opioids are known as drugs with direct effect to alleviate neuropathic pain and therefore, they can be considered as a potentially potent source of antinoceptive drugs (Nair et al., 2015). There has been a great concern regarding side effects of popular opioids such as morphine and codeine as to tolerance, addiction, hyperalgesia, abuse, and toxicity (Brantl et al., 1985).

By virtue of adverse effects of synthetic opioids on health, science has recently shifted its concentration on finding natural sources with antinoceptive effect. Interestingly, bioactive peptides from different resources such as wheat (Fukudome and Yoshikawa, 1993; Takahashi et al., 2000), camel milk (El Hatmi et al., 2016), and bovine blood (Brantl et al., 1989; Piot et al., 1992) were found to exert opioid effect. It is of great importance to know that these peptides are considered as opioid agonist-antagonist. In other words, they can have both agonist and antagonist effect. This is very imperative because as opioid agonists, they induce an analgesic effect, which is characteristically found in opioid ligands, whereas as opioid antagonists at the NK1 receptors, they block the signals induced by the pronociceptive peptides involved in pain signaling (Zhang et al., 2011). Furthermore, Huang et al. (2016) mentioned that the dynorphin/ $\kappa$ opioid (KOP) receptor system leads to adverse emotional conditions. When activated by selective agonists, the receptor system causes strong emotional consequences in humans and conditioned place aversion in animals (Huang et al., 2016). Therefore, opioid peptides from natural sources are very important due to their dual role as opioid agonist and antagonist. However, their application is still limited because of their varying influence on blood-brain barrier permeability, their sensitivity to metabolism inside the body, and lack of suitable delivery systems for them (Brantl et al., 1985).

\section{Relaxing effect}

Bioactive peptides from natural resources, especially milk and its derivatives, have been indicated to have relaxing effect. Historically, Miclo et al. (2001) mentioned that cow or human breast milk have tranquilizing effect because of their benzodiazepine-like molecules. They claimed that a peptide released by trypsin-mediated hydrolysis of $\alpha_{\mathrm{s} 1}$-casein showed benzodiazepine-like effect (Miclo et al., 2001). A few years later, Messaoudi et al. (2005), also, reported that a tryptic hydrolysate from bovine milk $\alpha_{\mathrm{S} 1}$-casein decreased stress level in the treated 
Table 3. Effects of bioactive peptides on nervous system.

\begin{tabular}{|c|c|c|c|c|}
\hline \multirow{2}{*}{$\begin{array}{l}\text { Effects } \\
\begin{array}{l}\text { Opioid and } \\
\text { antinociceptive }\end{array}\end{array}$} & \multicolumn{2}{|c|}{ Origin } & Amino acid sequence (in single-letter code) & Reference \\
\hline & $\mathrm{TP}$ & Wheat & GYYPT, YPISL & $\begin{array}{l}\text { Takahashi et al., 2000; Fukudome and } \\
\text { Yoshikawa, } 1993\end{array}$ \\
\hline & TA & Bovine blood & YPWT, LVVYPWTQRF, VVYPWTQRF & Brantl et al., 1989; Piot et al., 1992 \\
\hline & $\mathrm{DE}$ & Lactabumin & YGLF,YLLF & Yoshikawa et al., 1986 \\
\hline & & Bovine milk & YPFPGP,YPFPGPI & Boutrou et al., 2013 \\
\hline & & Bovine /3-casein & YPFPGPI & Brantl et al., 1979 \\
\hline & & Bovine milk-derived lactoferrin & - & Hayashida et al., 2003 \\
\hline & & $\begin{array}{l}\text { Kefir microorganisms on bovine } \\
\text { milk }\end{array}$ & $\begin{array}{l}\text { YPFPGPI, YPVEPF, YPSYGLN, YPFPGPIPN, } \\
\text { YPFPGPIPNSLPQ }\end{array}$ & Dallas et al., 2016 \\
\hline & & Camel milk & YFPIQFVQSR,YPSYGIN & El Hatmi et al., 2016 \\
\hline & & Human milk & YVPFP, YPFV,YPFVE, YGLF & $\begin{array}{l}\text { Kampa et al., 1996; Kostyra et al., } \\
\text { 2004; Brantl, } 1985\end{array}$ \\
\hline & & Bovine milk-derived lactoferrin & - & Hayashida et al., 2003 \\
\hline & & Milk-derived & - & Tsuchiya et al., 2006 \\
\hline & & Human lactoferrin & - & Raju et al., 2005 \\
\hline \multirow[t]{3}{*}{ Relaxing peptides } & $\mathrm{DE}$ & Bovine Casein & YLGYLEQLLR, YLGYLEQ & $\begin{array}{l}\text { Cakir-Kiefer et al., 2011; Messaoudi } \\
\text { et al., } 2005\end{array}$ \\
\hline & & Bovine as1-casein & YLGYLEQLLR & $\begin{array}{l}\text { Miclo et al., 2001; Hernández- } \\
\text { Ledesma et al., } 2014\end{array}$ \\
\hline & & Bovine milk lactoferrin & - & $\begin{array}{l}\text { Takeuchi et al., 2003; Kamemori et al., } \\
2004\end{array}$ \\
\hline \multirow[t]{5}{*}{ Anti-amnesic } & AS & Tilapia & $\begin{array}{l}\text { Many peptides have been introduced. Please } \\
\text { refer to the related reference. }\end{array}$ & Huang et al., 2015a, b \\
\hline & & Shrimp waste & LFH & Li-Chan et al., 2016 \\
\hline & & Anchovy & - & Su et al., 2016 \\
\hline & TA & Porcine cerebral hydrolysate & $\begin{array}{l}\text { RILDWYKK, RVGSMEKART, RLSFDRVGSMEKA, } \\
\text { RWALNEDQMATEKL, KRFGYETEVMGASFRN, } \\
\text { KLISPFVGRILDWYKK, KSTGQDYAPADDPG } \\
\text { VNSVRE, KKSTGQDYAPADDPGVNSVRE, } \\
\text { RNKDEILELAGCDLLTIAPKL, } \\
\text { KQFTTVVADSSDFDSMKSYQPRD, } \\
\text { KLQQEGINCNMTLLFSFPQAVAAAKAKV }\end{array}$ & Zou et al., 2015 \\
\hline & TP & Defatted walnut meal & WSREEQEREE, ADIYTEEAGR & Chen et al., 2015 \\
\hline
\end{tabular}

$A S, T P, T A$, and DE stand for aquatic sources, terrestrial plants, terrestrial animals, and dairy \& eggs, respectively.

subjects compared to control subjects who only received placebo (Messaoudi et al., 2005). More recently, Zhao et al. $(2016 \mathrm{a}, \mathrm{b})$ stated that peptide fractions isolated from protein hydrolysate of croceine croaker (Pseudosciaena crocea) swim bladder exerted anti-fatigue and relaxing effect in mice (Zhao et al., 2016a, b).

It is noteworthy that relaxing effect of peptides from bovine milk-derived $\alpha_{\mathrm{s} 1}$-casein has long been emphasized; however, future studies are directed toward investigating this effect of peptides from other dairy and/or even nondairy sources.

\section{Anti-amnesic}

Amyloid beta $(\mathrm{A} \beta)$ is a proteolytic derivative of the large transmembrane protein amyloid precursor protein (APP) and it plays role in outbreak of Alzheimer Disease (AD). A $\beta$ generation occurs in the presence of $\beta$-secretase. Therefore, inhibition of $\beta$-secretase can be a potentially effective way to control and prevent $\mathrm{AD}$. A bioactive peptide, with the amino acid sequence of LFH, from shrimp waste with inhibitory activity against $\beta$-secretase was recently reported (Li-Chan et al., 2016).

Zou et al. (2015) claimed that bioactive peptides obtained from porcine cerebral hydrolysate have potential ability to protect against memory impairment caused by $\mathrm{Pb}^{2+}$ presumably by reducing the $\mathrm{Pb}^{2+}$ concentration of the blood and brain (Zou et al., 2015).

Moreover, Chen et al. (2015) examined the effect of defatted walnut meal hydrolysate on learning and memory in D-galactose-treated mice. They assumed that two peptides, i.e.,
WSREEQEREE and ADIYTEEAGR, from the hydrolysate are able to fight against memory and learning impairment in the mice.

Furthermore, in an in vitro study, Su et al. (2016) revealed that Anchovy (Coilia mystus) protein hydrolysate has therapeutic potential for memory deficit through inhibition of acetylcholinesterase (AChE). AChE is responsible for catalyzing hydrolysis of Ach into choline and acetic acid, which leads to reduction in acetylcholine (Ach) levels. Ach is a small-molecule neurotransmitter which regulates memory, concentration and consciousness (Su et al., 2016). Su et al. (2016) further followed up on their hypothesis in an in vivo trial on mice and stated that intervention by using the hydrolysate could improve spatial memory of scopolamine-impaired mice (Su et al., 2016).

\section{Effects on gastrointestinal system}

Table 4 presents an overview of reported effects of peptides on gastrointestinal system.

\section{Anti-obesity}

Obesity has turned into one of the most serious health problems in the current century and it is believed to elevate the probability of heart disease, type- 2 diabetes, obstructive sleep apnea, certain types of cancer, and osteoarthritis, among others (Micewicz et al., 2015). There has thus been a great deal of interest in anti-obesity drugs with satiating and appetite suppressant effects; however, the use of these drugs is limited due 
Table 4. Effects of bioactive peptides on gastrointestinal system.

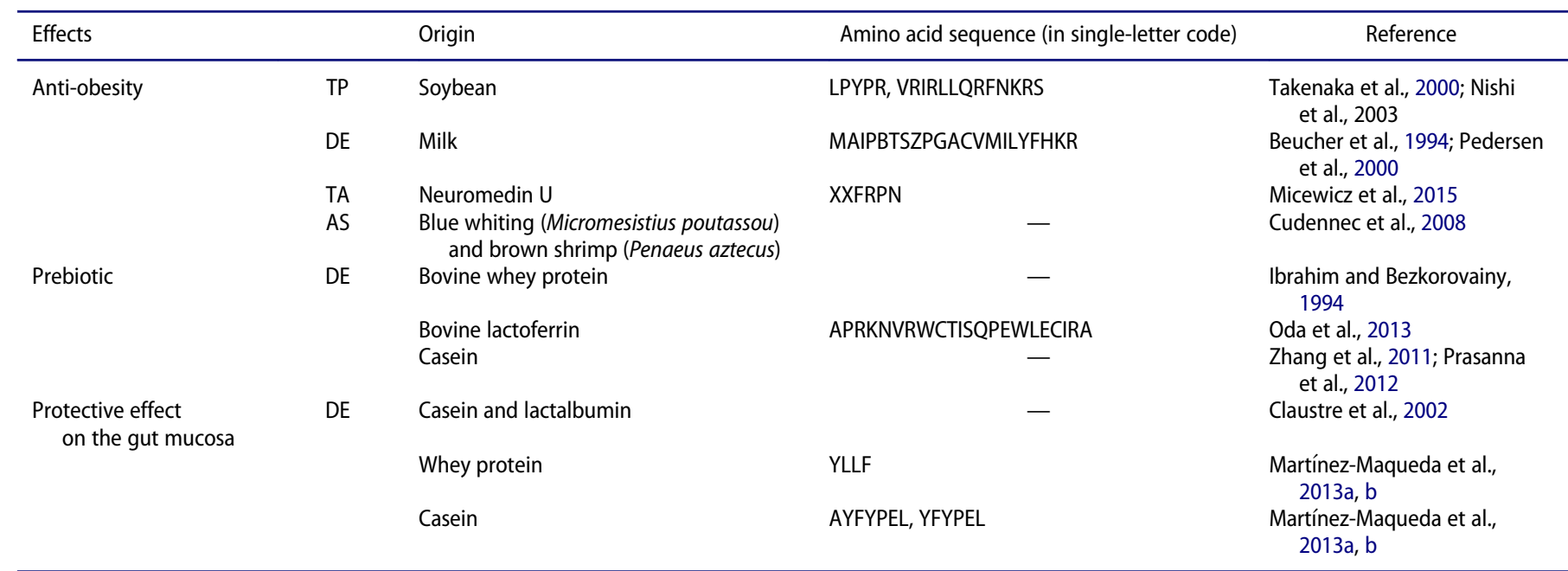

$\mathrm{AS}, \mathrm{TP}, \mathrm{TA}$, and DE stand for aquatic sources, terrestrial plants, terrestrial animals, and dairy \& eggs, respectively.

Uncommon amino acids are denoted by "X."

to their adverse effects such as depression and cardiovascular risks (Ziauddeen and Fletcher, 2013). Therefore, science has shifted its focus on bioactive agents without or with minimum side-effects from natural resources.

One of the most noticed ways the bioactive agents render their anti-obesity effect is through influence on cholecystokinin (CCK) release; CCK is one of the major intestinal regulatory peptides (Beucher et al., 1994) and an important physiologic endocrine factor in appetite control (Nishi et al., 2003a, b). Beucher et al. (1994) showed that glycomacropeptide, i.e., glycosylated forms of caseinomacropeptide (CMP), released from dietary casein during gastric digestion has satiating effect in rats via stimulation of CCK release by intestinal cells. This finding is supported by the results of Pedersen et al. (2000), who concluded that dietary amount of CMP can stimulate pancreatic secretion through CCK release. Furthermore, Nishi et al. (2003b) indicated that a fragment of soybean $\beta$-conglycinin with amino acid sequence VRIRLLQRFNKRS is responsible for its anorexigenic effect by stimulating CCK release. In an in vivo study, they had previously shown that $\beta$-conglycinin peptone suppresses food intake in rats (Nishi et al., 2003a).

More recently, (Micewicz et al., 2015) revealed that NM4$\mathrm{C}_{16}$, a truncated/lipid-conjugated neuromedin $\mathrm{U}(\mathrm{NmU})$ analog, has strong appetite suppressing effects in a diet-induced obese (DIO) mouse model; it is noteworthy that Neuromedin $\mathrm{U}(\mathrm{NmU})$ is an endogenous peptide with various physiological effects.

\section{Prebiotic effects}

Although most prebiotic agents promoting the growth and viability of probiotics like Bifidobacterium and Lactobacillus genera are currently nondigestible oligosaccharides ( $\mathrm{Yu}$ et al., 2016), bioactive peptides and proteins from various resources have been considered for their effects on probiotics. In one of the earliest attempts to find prebiotic effect in nonfiber products, Ibrahim and Bezkorovainy (1994) reported that $\alpha$-lactalbumin and $\beta$-lactoglubin had potent growth promoting influence on the probiotic Bifidobacterium Iongum. More recently, a prebiotic peptide from pepsin hydrolysate of bovine lactoferrin was found to exert bifidogenic effect (Oda et al., 2013).

Zhang et al. (2011) fractionated five casein hydrolysates produced by five different proteases and found that the $>3000 \mathrm{kDa}$ fractions were essential for stimulation of Lactobacillus bulgaricus and Streptococcus thermophiles. They further analyzed the total amino acid profiles of the ultra-filtered fractions and revealed that the hydrophilic amino acid residua including His, Lys, Glu and Ser are favorable for the prebiotic effect of the hydrolysates.

\section{Protective effect on the gut mucosa}

There is a protective viscoelastic mucous gel layer covering the luminal surface of the gastrointestinal tract. The layer, which is also termed as "gut barrier" (Moughan et al., 2013), is considered a barrier against the noxious luminal environment (Corfield et al., 2000). Mucosal tissue damage in parts of gastrointestinal tract might bring about the so-called inflammatory bowel diseases (IBDs) such as ulcerative colitis and Crohn's disease (Sluis et al., 2006). The main component of mucus layer is polymeric glycoproteins called mucins, which cover the epithelium of the gastrointestinal tract and epithelia in mammals (Montagne et al., 2004). Mucins are synthesized and secreted by specialized cells in intestinal epithelium, called goblet cells. In healthy mammas, there is a dynamic balance between mucin release by goblet cells and mucin loss through physical and proteolytic processes (Martínez-Maqueda et al., 2013a, b). In addition to internal factors such as hormones and cytokines, dietary regulation of mucin secretion has also been mentioned (Morel et al., 2003; Burger-van et al., 2009; Moughan et al., 2013).

In a study to determine effects of peptides derived from dietary proteins on mucus secretion, Claustre et al. (2002) revealed that two protein hydrolysates obtained by enzymatic hydrolysis of casein and lactalbumin prompted mucin release in rat jejunum. Later, Martínez-Maqueda et al. (2013a, b) found that two 
peptides derived from casein hydrolysate induce mucin production in human intestinal cells.

\section{In vitro vs. in vivo effects}

Bioactive peptides and protein hydrolysates from different sources have shown a very large number of beneficial effects. However, a majority of the studies have launched in vitro experiments to show the effects. Although there were a few in vivo studies on the effect of the peptides and hydrolysates using animal models, it seems that there is still a research gap in analyzing the effect of these peptides and hydrolysates in humans when applied as functional foods and/or nutraceuticals. Therefore, in addition to in vitro and in vivo studies using animal models, future investigations should be directed toward evaluation of the effects of bioactive peptides-enriched functional foods and nutraceuticals in humans. Needless to say, such studies demand interdisciplinary efforts in which nutritionists, food science experts, animal science experts, physiologists, medical researchers, biotechnologists, etc., should contribute in unison.

\section{Functional and antioxidant properties}

\section{Functional properties}

Several functional properties have been reported for protein hydrolysates. It is known that the specificity of the enzyme, degree of hydrolysis (DH) and bulk density of the proteins influence the functional properties of the hydrolysates (Multilangi et al., 1996; Chobert et al., 1996; Kristinsson and Rasco, 2000). The specificity of the enzyme influence amino acid residues and both DH and bulk density of the proteins influence the length of the peptides. The DH needs to be controlled to avoid excessive hydrolysis that can impair functionality and cause unfavorable effects of the produced hydrolysates (Mune, 2015). The functional properties discussed below are universal and not specific for whether the peptides are from fish, milk or vegetables, but depends on the origin of the protein.

\section{Solubility}

In general, solubility of hydrolysates is expected to increase with increased $\mathrm{DH}$ due to an increment in low molecular weight peptides and ionic groups during hydrolysis (Mutilangi et al., 1996, Chobert et al., 1988a, Kristinsson and Rasco, 2000). Additionally, the balance of hydrophilic and hydrophobic forces of peptides is also mentioned as an important cause of solubility enhancement (Kristinsson and Rasco, 2000; Gbogouri et al., 2004). Several reported studies have also confirmed that increasing DH increases solubility of protein hydrolysates (Quaglia and Orban, 1987; Chobert et al., 1988a, b; Mutilangi et al., 1996; Linarès et al., 2000; Gbogouri et al., 2004; Klompong et al., 2007; Souissi et al., 2007; Balti et al., 2010; Geirsdottir et al., 2011). The solubility of the hydrolysates is especially improved at the proteins isoelectric point, pI (Chobert et al., 1988b).

\section{Emulsifying properties}

Emulsifying properties of hydrolysates are directly connected to their surface properties and are influenced by the extent of hydrolysis and enzyme treatment (Kristinsson and Rasco, 2000). This is due to the changes in molecule size, charge and distribution of hydrophilic and hydrophobic parts. Hydrolysates are surface active due to their hydrophilic and hydrophobic functional groups, and can absorb to an interface and thus work as an emulsifier. Whether hydrolysates improve the emulsifying properties more than the native proteins do is not certain. Reported results for emulsion capacity and stability do not show any clear trend due to different DH and enzyme treatment for the obtained hydrolysates. Different emulsifying properties of the hydrolysates have been reported. Some studies showed improved emulsion properties (Chobert et al., 1988b; Turgeon et al., 1991; Balti et al., 2010) whereas others showed that hydrolysates had decreased emulsifying properties compared to those of the native protein (Lee et al., 1987; Chobert et al., 1988a; Mutilangi et al., 1996; Klompong et al., 2007; Souissi et al., 2007; Taheri et al., 2014; Mune, 2015; Zou et al., 2016). The lack in improved emulsifying properties may be caused by too high $\mathrm{DH}$ of the hydrolysates. In order to retain or improve the emulsifying properties of hydrolysates over the native proteins, the extent of hydrolysis has to be carefully controlled. Low DH is recommended, since extensive hydrolysis results in a drastic loss of emulsifying properties (Kristinsson and Rasco, 2000; Gbogouri et al., 2004; Taheri et al., 2014; García-Moreno et al., 2017). High DH leads to smaller peptides, which are not able to form a stable film surrounding the fat globules (Lee et al., 1987; Chobert et al., 1988a). This is due to lack of unfolding and reorientation of smaller peptides compared to larger peptides (Gbogouri et al., 2004).

\section{Foaming properties}

As for the emulsifying properties (section 3.2.2), foaming properties are connected with the surface activity of the hydrolysates (Kristinsson and Rasco, 2000). Thus, the factors relevant to foaming are similar to those required for emulsification. Foam capacity of proteins can be improved by making them more flexible (hydrolysis) and exposing more hydrophobic residues for the adsorption at the air-water interface (Multilangi et al., 1996). Several studies showed decreased foaming stability for protein hydrolysates compared to that of the untreated proteins (Linarès et al., 2000; Klompong et al., 2007; Souissi et al., 2007; Mune, 2015; Zou et al., 2016). Some studies, on the other hand, reported increased foaming capacity of hydrolysates compared to untreated proteins (Kuehler and Stine, 1974; Balti et al., 2010; Mune 2015). An increment in foam capacity due to limited hydrolysis is attributed to more air incorporated into solution of small peptides due to rapid diffusion of peptides to the air-water interface (Kuehler and Stine, 1974; Mune 2015). However, small peptides do not have the strength required to form stable foams. Thus, high DH has a negative influence on the foaming stability (Kristinsson and Rasco, 2000).

\section{Gelling properties}

Gelation is favored by large molecules of proteins since they form extensive networks by cross-linking in three-dimensions (Wang and Damodaran, 1990, Jeewanthi et al., 2015). On the other hand, the structure of the proteins is altered during hydrolysis since buried hydrophobic groups are exposed and free to interact. It is proposed that noncovalent interactions, 
mainly electrostatic and hydrophobic, are major interacting forces since they promote aggregation and subsequent gel settings (Fuke et al., 1985, Otte et al., 1996, Otte et al., 1997, Jeewanthi et al., 2015). However, Kuipers et al. (2005) concluded based on their findings that the aggregation is not a simple balance between repulsive electrostatic and attractive hydrophobic interactions, but much more complex. Gelling properties are observed both with limited hydrolysis (Ju et al., 1995; Otte et al., 1996; Kuipers et al., 2005) and more extensive hydrolysis, $\mathrm{DH}>15 \%$ (Doucet et al., 2001).

\section{Water holding capacity (WHC)}

Hydrolysis of proteins affects the ability of the formed hydrolysates to adsorb and bind water. A linear relationship between amounts of certain amino acids and WHC has been observed for fish protein hydrolysates. Decreasing amount of glycine, arginine, alanine, hydroxyproline, and sum of hydrophobic amino acids increased the WHC (Šližyte et al., 2005). Moreover, WHC of hydrolysates increased with increasing DH. During enzymatic hydrolysis, the presence of polar groups $(-\mathrm{COOH}$ and $-\mathrm{NH} 2)$ increases, and it is assumed that this has a substantial effect on the increased WHC observed for hydrolysates (Balti et al., 2010). However, others stated that the DH did not affect the WHC (Geirsdottir et al., 2011). Additionally, Choi et al. (2009) observed higher WHC of the insoluble fraction of protein hydrolysates than the soluble fraction.

\section{Fat absorption capacity (FAC)}

The mechanism of fat absorption capacity (FAC) is attributed to the physical entrapment of oil in a protein network. Some studies have shown no effect of DH on the FAC (Amiza et al., 2012) or no correlation between DH and FAC (Souissi et al., 2007). Other studies reported improved FAC of hydrolysates at low $\mathrm{DH}$ and that further increment in $\mathrm{DH}$ significantly decreased FAC (Geirsdottir et al., 2011; Gbogouri et al., 2004; Balti et al., 2010; García-Moreno et al., 2017). Low DH could even improve the FAC over the native protein (Balti et al., 2010, Mune, 2015). These observations could be explained by hydrolysis, which can liberate some peptides from the native protein, which would enhance the flexibility of the hydrolysates. The extensive hydrolysis would break many peptide bonds, thus contributing to the decrease of FAC (Souissi et al., 2007; Balti et al., 2010). As observed for the WHC, the FAC was higher for the insoluble fraction of protein hydrolysates than the soluble fraction (Choi et al., 2009). However, the opposite has also been observed (Yin et al., 2010). The different observations may be due to different $\mathrm{DH}$ of the soluble fraction, thus, different molecular sizes of the peptides.

\section{Mineral binding}

Bioavailability of minerals can be improved in the presence of hydrolysates due to increased mineral solubility. It is reported that hydrolysates can exert binding activity towards different minerals such as calcium (Jung and Kim, 2007, Huang et al., 2011, Chen et al., 2014), iron (Chaud et al., 2002; Lee and Song, 2009a), copper (Eckert et al., 2014), and zinc (Eckert et al., 2014). Different molecular sizes of the mineral binding peptides ranging from 1 to $1.5 \mathrm{kDa}$ have been reported (Jung and Kim, 2007; Lee and Song, 2009b; Chen et al., 2014). However, Huang et al. (2011) observed highest binding affinity (calcium) with the lowest molecular weight fraction $(<1 \mathrm{kDa})$.

\section{Antioxidant properties}

Oxidation processes have detrimental effects on human health and food quality. In the body, oxidants cause damage of lipid membranes, structural proteins and DNA which leads to degenerative diseases such as cancer, immune system decline, cardiovascular diseases as well as the aging process (Shahidi, 2015). In food, lipid oxidation, which is catalyzed by heat, light, enzymes or metals, leads to the formation of off-flavors and odors which negatively affects food function and nutrition. Moreover, food quality is further degraded by co-oxidation of proteins and vitamins (Schaich, 2016). Due to the potential health hazards of synthetic antioxidants (e.g., butylated hydroxyanisole (BHA), butylated hydroxytoluene (BHT), propyl gallate (PG), and tertiary butylhydroquinone (TBHQ)), the employment of natural antioxidants has gained an increasing interest (Shahidi and Zhong, 2015). Peptides have been reported to exhibit antioxidant activity due to their properties to scavenge free radicals, donate electrons and/or chelate metals (Aluko, 2015). As for other bioactivities, peptides size, amino acid composition and structure are the factors affecting the ability of the peptides to inhibit oxidation (Sarmadi and Ismail, 2010). Particularly important is the presence of hydrophobic amino acids (e.g., A, L, V, G, P, F) which favors peptide interaction with lipids resulting in an enhanced radical scavenging activity. Similarly, the presence of electron donors (e.g., E, M, N) and amino acids exhibiting chelating activity (e.g., D, E, H, W) also increases the antioxidant activity of the peptides (Aluko, 2015). Comprehensive reviews have been published on the production of antioxidant peptides from proteins of different origin such as: i) aquatic resources (e.g., algae, oysters, mussel, sardine, bonito, tuna, mackerel, yellowfin sole, hok, squid, salmon, eel, round scad, tilapia, channel catfish, horse mackerel, monkfish) (Samaranayaka and Li-Chan, 2011; Wu et al., 2015a, b; Sila and Bougatef, 2016), ii) terrestrial plants (e.g., wheat, corn, rye, kamut, spelt, rapeseed/flaxseed, rice, soybean, cacao seeds, hempseed, pea) (Malaguti et al., 2014; Aluko, 2015; Rizzello et al., 2016), iii) terrestrial animals (e.g., porcine myofibrils, dry-cured ham, buffalo horn, porcine skin) (Mora et al., 2014), iv) dairy (bovine, ovine, buffalo and human milks, whey protein) (Power et al., 2013; El-Salam and El-Shibiny, 2013; Brandelli, et al., 2015), and v) eggs (e.g., egg white ovalbumin, egg white lysozyme, egg yolk) (Yu et al., 2014; Nimalaratne and $\mathrm{Wu}, 2015)$. Most studies evaluated the antioxidant activity of the hydrolysates/peptides in vitro using different methods such as DPPH scavenging activity, reducing power, ABTS scavenging activity, $\mathrm{Fe}^{2+}$ chelating activity, $\beta$-carotene bleaching preventing activity, linoleic acid autoxidation inhibition activity (Chalamaiah et al., 2012). Some studies also investigated the ability of the hydrolysates/peptides to inhibit lipid oxidation in real food systems such fish oil in water emulsions (Farvin et al., 2014; García-Moreno et al., 2016; Ghelichi et al., 2017) or fish oil microcapsules (Tamm et al., 2015; Morales-Medina et al., 2016). Finally, only a few works are devoted to studying the antioxidant activity of peptides in cell-based and in vivo systems (Chakrabarti et al., 2014). 


\section{Commercial applications of bioactive peptides and hydrolysates}

Many of the bioactive peptides mentioned in this review and previously reported studies occur naturally in several traditionally consumed foods (e.g., fermented foods) or during biological processes inside the human body (e.g., enzymatic reactions). Nevertheless, bioactive peptides and hydrolysates have recently been added to numerous products gaining the name "functional foods" and "nutraceuticals." Besides, bioactive peptides and hydrolysates are used to produce drugs as well as cosmetics and health-promoting products (Hartmann and Meisel, 2007). Table 5 represents examples of commercially available products in which bioactive peptides and protein hydrolysates from different sources have been used.

Despite the recent surge in manufacture of commercial products using bioactive peptides and hydrolysates, industries seem not to be at the cutting edge of this sector of biotechnology. In other words, although there have been virtually uncountable number of scientific investigations on functionality and bioactivity of peptides and hydrolysates derived from natural sources, very few of the findings have been operationalized in industry. This might be due to several factors including high operational and set-up costs, sensory concerns, low market acceptability on account of uncertainty upon manufacturers' claims and potential side effects, unsatisfactory return on invested capital, legislative and religious issues in some countries, and unaffordability of the products for the public. Likewise, Li-Chan (2015) listed a few challenges in commercialization of nutraceuticals and functional foods containing bioactive peptides as follows: (i) complications in methodology for quality assurance; (ii) sparse data on bioavailability and metabolic fate; (iii) inadequate clinical evidence of bioefficacy; and (iv) bitterness of peptides (Li-Chan, 2015). In addition, when considered to be added as antioxidant agents in food systems, bioactive peptides and hydrolysates should meet a few demands; they should be affordable and competitive with synthetic antioxidants, not cause toxicity in human body, be effective at low concentrations, be able to tolerate processing operations and be stable in the finished products, and present favorable organoleptic properties (Sila and Bougatef, 2016).

Challenges and concerns in application of bioactive peptides and hydrolysates in different industries may also depend on the source(s) from which the peptides and hydrolysates are obtained. Harnedy and FitzGerald (2012) named large-scale production, compatibility with various food matrices, gastrointestinal stability, bioavailability, and long term stability as the main concerns in manufacture of functional foods containing bioactive peptides or protein hydrolysates with marine origins (Harnedy and FitzGerald, 2012). Additionally, Lafarga and Hayes (2016) stated that peptides and hydrolysates from casein and whey proteins might cause allergy in some consumers (Lafarga and Hayes, 2016). Korhonen (2009) indicated that milk-derived proteins, e.g., casein and whey, are the most prevalent source of functional foods and nutraceuticals containing bioactive peptides; however, production of commercially available products from these sources have been restricted by lack of suitable large-scale technologies; he suggested that nanofiltration and ultrafiltration techniques can be adopted to overcome technological barriers to make industrial and commercial use of bioactive peptides from milk proteins (Korhonen, 2009). Udenigwe and Rajendran (2016) uttered that the most notable hindrance in commercialization of functional foods containing plastein is the costs levied by high price of enzymes required for plastein reaction (Udenigwe and Rajendran, 2016). Grienke et al. (2014) pointed to the necessity of collaboration between academia and industry to reach a win-win condition to exploit favorable bioactive peptides from mussel meat and incorporate them in functional foods; however, they presumed that challenges such as stability, bitterness, and lack of appropriate food-grade formulation procedures account for the current gap from lab beakers to factory batches. They further shed light on the importance of interdisciplinary expertise in order to the development of functional foods, food ingredients, or pharmaceuticals from mussels (Grienke et al., 2014).

Another bottleneck in application of bioactive peptides and hydrolysates is the lack of scientific studies on the effects of peptides on humans. Although there have been several in vivo investigations proving the bioactivity of peptides and hydrolysates in

Table 5. Examples of commercially available products from bioactive peptides and hydrolysates.

\begin{tabular}{|c|c|c|c|c|}
\hline Product & Source & Claimed application & Type of fraction & Manufacturer \\
\hline Lactium $^{\circledR}$ & Milk & Relaxing & Peptide (YLGYLEQLL) & Ingredia, Arras Cedex, France \\
\hline Myprotein $^{\mathrm{TM}}$ & Whey & Sport nutrition & Whole hydrolysate & The Hut, Ltd, UK \\
\hline Sato Marine Super P & Sardine & Antihypertensive & Peptide (VY) & Sato Pharmaceutical Co., Ltd., Tokyo, Japan \\
\hline Hyvital ${ }^{\circledR}$ & Whey or casein & Infant nutrition & Whole hydrolysate & FrieslandCampina, Netherlands \\
\hline Proyield $^{\circledR}$ & $\begin{array}{l}\text { Nonanimal protein (soy, cotton } \\
\text { seed, wheat, pea) }\end{array}$ & Biopharmaceutical cell culture media & Whole hydrolysate & FrieslandCampina, Netherlands \\
\hline Stedygro ${ }^{\circledR}$ & $\begin{array}{l}\text { Protein from casein, soy, malt, } \\
\text { gelatin, and cotton }\end{array}$ & Microbial culture media & Whole hydrolysate & FrieslandCampina, Netherlands \\
\hline Lacprodan $^{\circledR}$ & Protein from casein and whey & Sport nutrition and beverage & Whole hydrolysate & Arla Foods Ingredients, Denmark \\
\hline Ameal S & Milk casein & ACE inhibition & Peptides (IPP and VPP) & Calpis, Japan \\
\hline Vasotensin ${ }^{\circledR}$ & Bonito & Anti-hypertension & Peptide (LKPNM) & Metagenics, US \\
\hline Peptide Nori S & Porphyra yezoensis & Anti-hypertension & Peptide (AKYSY) & Riken Vitamin, Japan \\
\hline Stabilium ${ }^{\circledR} 200$ & Fish & Relaxing & Whole hydrolysate & Yalacta, France \\
\hline Seishou-sabou & Bovine and porcine blood & Anti-obesity & Peptide (VVYP) & Moringa \& Co., Ltd., Japan \\
\hline Marine peptide & Sardine & ACE inhibition & Peptides & SenmiEkisu, Japan \\
\hline BioZate & Whey & Anti-hypertension & Peptides & Davisco Foods, US \\
\hline $\mathrm{NOW}^{\circledR}$ & Whey & Sport nutrition & Whole hydrolysate & NOWfoods, US \\
\hline Nutripeptin ${ }^{\mathrm{TM}}$ & Cod & Hypotriglyceridemic & Whole hydrolysate & Nutrimarine Life Science AS, Norway \\
\hline VERISOL ${ }^{\circledR}$ & Collagen & Anti-aging & Peptides & GELITA Inc., US \\
\hline Remake CholesterolBlock & Soy protein & Hypocholesterolemic & Peptide (CSPHP) & Kyowa Hakko, Japan \\
\hline
\end{tabular}


animal models, the results of these studies cannot be confidently generalized to humans due to the disagreement between human and animal studies. Nongonierma and FitzGerald (2016a) explained that the discrepancy between human and animal studies could be caused by two major reasons, i.e., biological differences between humans and animals and differences in experimental set-up (Nongonierma and FitzGerald, 2016b).

In addition to their application in functional foods and nutraceuticals, bioactive peptides and hydrolysates are used to produce drugs and cosmetics. Bioactive peptides are prioritized as drugs over proteins and antibodies since they have a higher capability of penetration into tissues by virtue of their smaller size. Furthermore, peptides with therapeutic effects are commonly less immunogenic than recombinant proteins and antibodies (Vlieghe et al., 2010). However, peptide-based drugs industry encounters operational logjams such as physical and chemical instability, short in vivo half-lives, and low oral bioavailability; interestingly, a portion of these logjams can be broken by encapsulation of the drugs in order to improve their stability and bioavailability (Kadam et al., 2015). Furthermore, use of antimicrobial peptides in drug industry has been limited to topical applications to cure surface infections, whereas parenteral and oral applications of these peptides are strongly restricted due to such factors as toxicity. However, recent developments like fully synthetic peptides and peptidomimetics (i.e., synthetic molecules mimicking peptides) have opened new avenues in order to rid peptide-based drug making industry of the technological obstacles (Vlieghe et al., 2010; Narayana and Chen, 2015). On the other hand, natural bioactive peptides have gained more attention in cosmetics industry rather than drug making, which is justifiable since cosmetics are consumed topically and therefore, toxicity of natural peptides in systemic applications is a minor concern when it comes to the production of natural-peptide-based cosmetics. Bioactive peptides have been specifically emphasized in skincare and cosmetic dermatology because of their ability to stimulate collagen and render botox-like antiwrinkle effect (Fields et al., 2009).

To sum up, there is still a long way to be paved to make use of bioactive peptides from natural resources in the so-called peptide-based products. In recent years, more and more companies have inclined toward manufacture of functional foods and nutraceuticals from bioactive peptides and hydrolysates although it seems that these products have not gained widespread publicity, yet. This might in general be caused by two main factors, i.e., technological hurdles and high price of these products in the market. Nevertheless, functional foods and nutraceuticals, reportedly, account for the major portion of products based upon bioactive peptides and hydrolysates from natural sources. Moreover, medicinal applications of these peptides have been restricted to topically used products because of concerns over toxicity of the peptides when applied systemically. Of course, alternative technologies such as fully synthetic peptides and peptidomimetics have been proposed to overcome these problems. However, there has been a recent spark in production of anti-aging cosmetics based on bioactive peptides from natural resources with appropriate level of market acceptance.

\section{Conclusion}

Protein hydrolysates have been produced from variety of sources with plant and animal origins through chemical, enzymatic, and microbial procedures. Each of these methods have their own cons and pros but they all share a common disadvantage in terms of the bitter taste of final products that limit their applications. Different methods have been proposed to reduce bitterness of the peptides. Despite a few optimistic findings, no single method has been presented to fully remove the bitter taste of the peptides to be economical in industrial scales. A recent trend in this regard is the characterization and purification of peptides with stronger and more specific effects. The peptides have shown different effects on immune, cardiovascular, nervous, and gastrointestinal systems. They have also been found to exert functional and antioxidant properties in food systems. In spite of the recent interest in production of peptidebased foods, nutraceuticals, and pharmaceuticals in commercial scale, there is still a gap between wide academic findings and commercialization of bioactive peptides from natural resources.

\section{References}

Abdul-Hamid, A., Bakar, J. and Bee, G. H. (2002). Nutritional quality of spray dried protein hydrolysate from Black Tilapia (Oreochromis mossambicus). Food Chem. 78:69-74.

Adler-Nissen, J. (1986). Enzymic Hydrolysis of Food Proteins. Elsevier Applied Science, London.

Adje, E. Y., Balti, R., Kouach, M., Guillochon, D. and Nedjar-Arroume, N. (2011). $\alpha 67-106$ of bovine hemoglobin: a new family of antimicrobial and angiotensin I-converting enzyme inhibitory peptides. Eur. Food Res. Technol. 232:637-646.

Aguirre, L., Hebert, E. M., Garro, M. S. and Savoy de Giori, G. (2014). Proteolytic activity of lactobacillus strains on soybean proteins. LWT Food Sci. Technol. 59:780-785.

Ahn, C. B., Je, J. Y. and Cho, Y. S. (2012). Antioxidant and anti-inflammatory peptide fraction from salmon byproduct protein hydrolysates by peptic hydrolysis. Food Res. Int. 49:92-98.

Akin, O., Temelli, F. and Köseoğlu, S. (2012). Membrane applications in functional foods and nutraceuticals. Crit. Rev. Food Sci. 52:347-371.

Aluko, R. (2015). Amino acids, peptides, and proteins as antioxidants for food preservation. In: Handbook of Antioxidants for Food Preservation, pp. 105-140. Shahidi, F., Ed., Woodhead Publishing, Cambridge.

Amadou, I., Le, G. W., Shi, Y. H. and Jin, S. (2011). Reducing, radical scavenging, and chelation properties of fermented soy protein meal hydrolysate by Lactobacillus Plantarum Lp6. Int. J. Food Prop. 14:654-665.

Amiza, M. A., Kong, Y. L. and Faazaz, A. L. (2012). Effects of degree of hydrolysis on physicochemical properties of cobia (Rachycentron canadum) frame hydrolysates. Int. Food Res. J. 19(1):199-206.

Anderson, W. G., Ali, M. F., Einarsdottir, I. E., Schaffer, L., Hazon, N. and Conlon, J. M. (2002). Purification, characterization, and biological activity of insulins from the spotted dogfish, Scyliorhinus canicula, and the hammerhead shark, Sphyrna lewini. Gen. Comp. Endocrinol. 126:113-122.

Andjelic, C. D., Planelles, V. and Barrows, L. R. (2008). Characterizing the anti-HIV activity of papuamide. Mar. Drugs. 6:528-549.

Aravind, S. R. and Krishnan, L. K. (2016). Curcumin-albumin conjugates as an effective anti-cancer agent with immunomodulatory properties. Int. Immunopharmacol. 34:78-85.

Arihara, K. (2006). Strategies for designing novel functional meat products. Meat Sci. 74:219-229.

Arihara, K., Nakashima, Y., Mukai, T., Ishikawa, S. and Itoh, M. (2001). Peptide inhibitors for angiotensin I-converting enzyme from enzymatic hydrolysates of porcine skeletal muscle proteins. Meat Sci. 57:319-324.

Ashar, M. N. and Chand, R. (2004). Fermented milk containing ACEinhibitory peptides reduces blood pressure in middle aged hypertensive subjects. Milchwissenschaft - Milk Sci. Int. 59:363-366. 
Attoub, S., Arafat, H., Mechkarska, M. and Conlon, J. M. (2013). Antitumor activities of the host-defense peptide hymenochirin-1B. Regul. Pept. 187:51-56.

Aubes-Dufau, I., Capdevielle, J., Seris, J. L. and Combes, D. (1995). Bitter peptide from hemoglobin hydrolysate: isolation and characterization. FEBS Lett. 364:115-119.

Babini, E., Tagliazucchi, D., Martini, S., Dei Più, L. and Gianotti, A. (2017). LC-ESI-QTOF-MS identification of novel antioxidant peptides obtained by enzymatic and microbial hydrolysis of vegetable proteins. Food Chem. 228:186-196.

Bah, C. S. F., Carne, A., McConnell, M. A., Mros, S. and Bekhit, A. E. D. A. (2016). Production of bioactive peptide hydrolysates from deer, sheep, pig and cattle red blood cell fractions using plant and fungal protease preparations. Food Chem. 202:458-466.

Ballard, K. D., Bruno, R. S., Seip, R. L., Quann, E. E., Volk, B. M., Freidenreich, D. J., Kawiecki, D. M., Kupchak, B. R., Chung, M. Y., Kraemer, W. J. and Volek, J. S. (2009). Acute ingestion of a novel whey-derived peptide improves vascular endothelial responses in healthy individuals: a randomized, placebo controlled trial. Nutr. J. 8:1-11.

Balseiro, P., Falco, A., Romero, A., Dios, S., Martínez-Lopez, A., Figueras, A., Estepa, A. and Novoa, B. (2011). Mytilus galloprovincialis myticin C: A chemotactic molecule with antiviral activity and immunoregulatory Properties. PLoS One. 6(8):e23140.

Balti, R., Bougatef, A., Ali, N. E. H., Zekri, D., Barkia, A. and Nasri, M. (2010). Influence of degree of hydrolysis on functional properties and angiotensin I-converting enzyme-inhibitory activity of protein hydrolysates from cuttlefish (Sepia officinalis) by-products. J. Sci. Food Agr. 90:2006-2014.

Balti, R., Bougatef, A., Sila, A., Guillochon, D., Dhulster, P. and NedjarArroume, N. (2015). Nine novel angiotensin I-converting enzyme (ACE) inhibitory peptides from cuttlefish (Sepia officinalis) muscle protein hydrolysates and antihypertensive effect of the potent active peptide in spontaneously hypertensive rats. Food Chem. 170:519-525.

Banerjee, P. and Shanthi, C. (2012). Isolation of novel bioactive regions from bovine achilles tendon collagen having angiotensin I-converting enzyme-inhibitory properties. Process Biochem. 47:2335-2346.

Bao, Y., Wang, J., Li, C., Li, P., Wang, S. and Lin, Z. (2016). A preliminary study on the antibacterial mechanism of Tegillarca granosa hemoglobin by derived peptides and peroxidase activity. Fish Shellfish Immunol. 51:9-16.

Battison, A. L., Summerfield, R. and Patrzykat, A. (2008). Isolation and characterisation of two antimicrobial peptides from haemocytes of the American lobster Homarus americanus. Fish Shellfish Immunol. 25:181-187.

Benjakul, S., Binsan, W., Visessanguan, W., Osako, K. and Tanaka, M. (2009). Effects of flavourzyme on yield and some biological activities of mungoong, an extract paste from the cephalothorax of white shrimp. J. Food Sci. 74:S73-S80.

Bergaoui, I., Zairi, A., Tangy, F., Aouni, M., Selmi, B. and Hani, K. (2013). In vitro antiviral activity of dermaseptin $S$ and derivatives from amphibian skin against herpes simplex virus type 2. J. Med. Virol. 85:272-281.

Bernardini, R. D., Mullen, A. M., Bolton, D., Kerry, J., O’Neill, E. and Hayes, M. (2012). Assessment of the angiotensin-I-converting enzyme (ACE-I) inhibitory and antioxidant activities of hydrolysates of bovine brisket sarcoplasmic proteins produced by papain and characterisation of associated bioactive peptidic fractions. Meat Sci. 90:226-235.

Berthou, J., Migliore-Samour, D., Lifchitz, A., Delettre, J., Floch, F. and Jolles, P. (1987). Immunostimulating properties and three-dimensional structure of two tripeptides from human and cow caseins. FEBS Lett. 218:55-58.

Beucher, S., Levenez, F., Yvon, M. and Corring, T. (1994). Effects of gastric digestive products from casein on CCK release by intestinal cells in rat. J. Nutr. Biochem. 5:578-584.

Boonla, O., Kukongviriyapan, U., Pakdeechote, P., Kukongviriyapan, V., Pannangpetch, P. and Thawornchinsombut, S. (2015). PeptidesDerived from Thai rice bran improves endothelial function in $2 \mathrm{~K}-1 \mathrm{C}$ renovascular hypertensive rats. Nutrients. 7:5783-5799.

Bougatef, A., Nedjar-Arroume, N., Manni, L., Ravallec, R., Barkia, A., Guillochon, D. and Nasri, M. (2010). Purification and identification of novel antioxidant peptides from enzymatic hydrolysates of sardinelle (sardinella aurita) by-products proteins. Food Chem. 118:559-565.

Boutrou, R., Gaudichon, C., Dupont, D., Jardin, J., Airinei, G., MarssetBaglieri, A., Benamouzig, R., Tome, D. and Leonil, J. (2013). Sequential release of milk protein-derived bioactive peptides in the jejunum in healthy humans. Am. J. Clin. Nutr. 97:1314-1423.

Brandelli, A., Daroit, D. J. and Corrêa, A. P. F. (2015). Whey as a source of peptides with remarkable biological activities. Food Res. Int. 73:149161.

Brantl, V. (1985). Novel opioid peptides derived from human B-Casein: Human $\beta$-Casomorphins. Eur. J. Pharmacol. 106:213-214.

Brantl, V., Gramsch, Ch., Lottspeich, F., Henschen, A., Jaeger, K. H. and Herz, A. (1985). Novel opioid peptides derived from Mitochondrial Cytochrome b: Cytochrophins. Eur. J. Pharmacol. 111:293-294.

Brantl, V., Gramsch, C., Lottspeich, F., Mertz, R., Jaeger, K. H. and Herz, A. (1989). Novel opioid peptides defived from hemoglobin: hemorphins. Eur. J. Pharmacol. 125:309-310.

Brantl, V., Teschemacher, H., Henschen, A. and Lottspeich, F. (1979). Novel opioid peptides derived from casein (B-Casomorphins). Hoppe Seylers Z Physiol. Chem. 360(9):1211-1216.

Burger-van, P. N., Vincent, A., Puiman, P. J., Van der Sluis, M., Bouma, J., Boehm, G., Van Goudoever, J. B., Van Seuningen, I. and Renes, I. B. (2009). The regulation of intestinal mucin MUC2 expression by shortchain fatty acids: implications for epithelial protection. Biochem. $J$. 420:211-219.

Butikofer, U., Meyer, J., Sieber, R. and Wechsler, D. (2007). Quantification of the angiotensin-converting enzyme-inhibiting tripeptides Val-ProPro and Ile-Pro-Pro in hard, semi-hard and soft cheeses. Int. Dairy J. 17:968-975.

Byun, H. G. and Kim, S. K. (2001). Purification and characterization of angiotensin I converting enzyme (ACE) inhibitory peptides from Alaska pollack (Theragra chalcogramma) skin. Process Biochem. 36:1155-1162.

Cakir-Kiefer, C., Roux, Y. L., Balandras, F., Trabalon, M., Dary, A., Laurent, F., Gaillard, J. L. and Miclo, L. (2011). In vitro digestibility of $r$ Casozepine, a benzodiazepine-like peptide from bovine casein, and biological activity of its main proteolytic fragment. J. Agric. Food Chem. 59:4464-4472.

Capriotti, A. L., Caruso, G., Cavaliere, C., Samperi, R., Ventura, S., Chiozzi, R. Z. and Lagana, A. (2015). Identification of potential bioactive peptides generated by simulated gastrointestinal digestion of soybean seeds and soy milk proteins. J. Food Comp. Anal. 44:205-213.

Chabance, B., Jolles, P., Izquierdo, C., Mazoyer, E., Francoual, C., Drouet, L. and Fiat, A. M. (1995). Characterization of an antithrombotic peptide from K-casein in newborn plasma after milk ingestion. Brit. J. Nut. 73:583-590.

Chabance, B., Marteau, P., Rambaud, J. C., Migliore-samour, D., Boynard, M., Perrotin, P., Guillet, R., Jolles, P. and Fiat, A. M. (1998). Casein peptide release and passage to the blood in humans during digestion of ilk or yogurt. Biochhme. 80:155-165.

Chabeaud, A., Vandanjon, L., Bourseau, P., Jaouen, P. and Guérard, F. (2009). Fractionation by ultrafiltration of a saithe protein hydrolysate (pollachius virens): Effect of material and molecular weight cut-off on the membrane performances. J. Food Eng. 91:408-414.

Chakrabarti, S., Poidevin, M. and Lemaitre, B. (2014). The Drosophila MAPK p38c regulates oxidative stress and lipid homeostasis in the intestine. PLoS Genet. 10:e1004659.

Chalamaiah, M., Dinesh kumar, B., Hemalatha, R. and Jyothirmayi, T. (2012). Fish protein hydrolysates: Proximate composition, amino acid composition, antioxidant activities and applications: A review. Food Chem. 135:3020-3038.

Chan, Y. S. and Ng, T. B. (2013). Northeast red beans produce a thermostable and $\mathrm{pH}$-Stable defensin-Like peptide with potent antifungal activity. Cell. Biochem. Biophys. 66:637-648.

Chan, Y. S., Wong, J. H., Fang, E. F., Pan, W. L. and Ng, T. B. (2012). An antifungal peptide from Phaseolus vulgaris cv. brown kidney bean Acta Biochim. Biophys. 44:307-315.

Chang, C. Y., Wu, K. C. and Chiang, S. H. (2007). Antioxidant properties and protein compositions of porcine haemoglobin hydrolysates. Food Chem. 100:1537-1543. 
Charlet, M., Chernysh, S., Philippe, H., Hetru, C., Hoffmann, J. A. and Bulet, P. (1996). Isolation of several cysteine-rich antimicrobial peptides from the blood of a mollusc, mytilus edulis. J. Biol. Chem. 271:21808-21813.

Chaud, M. V., Izumi, C., Nahaal, Z., Shuhama, T., Bianchi, M. D. L. P. and Freitas, O. D. (2002). Iron derivatives from casein hydrolysates as a potential source in the treatment of iron deficiency. J. Agr. Food Chem. 50:871-877.

Chen, D., Mu, X., Huang, H., Nie, R., Liu, Z. and Zeng, M. (2014). Isolation of a calcium-binding peptide from tilapia scale protein hydrolysate and its calcium bioavailability in rats. J. Funct. Foods. 6:575-584.

Chen, G. W., Tsai, J. S. and Pan, B. S. (2007). Purification of angiotensin Iconverting enzyme inhibitory peptides and antihypertensive effect of milk produced by protease-facilitated lactic fermentation. Int. Dairy J. 17:641-647.

Chen, H., Zhao, M., Lin, L., Wang, J., Sun-Waterhouse, D., Dong, Y., Zhuang, M. and Su, G. (2015). Identification of antioxidative peptides from defatted walnut meal hydrolysate with potential for improving learning and memory. Food Res. Int. 78:216-223.

Chen, J. R., Okada, T., Muramoto, K., Suetsuna, K. and Yang, S. C. (2003). Identification of angiotensin I-converting enzyme inhibitory peptides derived from the peptic digest of soybean protein. J. Food Biochem. 26:543-554.

Cheung, L. K. Y., Aluko, R. E., Cliff, M. A. and Li-Chan, E. C. Y. (2015). Effects of exopeptidase treatment on antihypertensive activity and taste attributes of enzymatic whey protein hydrolysates. J. Funct. Foods. 13:262-275.

Chi, C. F., Wang, B., Wang, Y. M., Zhang, B. and Deng, S. G. (2015b). Isolation and characterization of three antioxidant peptides from protein hydrolysate of bluefin leatherjacket (Navodon septentrionalis) heads. J. Funct. Foods. 12:1-10.

Chobert, J. M., Bertrand-Harb, C. and Nicolas, M. G. (1988b). Solubility and emulsifying properties of caseins and whey proteins modified enzymatically by trypsin. J. Agr. Food Chem. 36:883-892.

Chobert, J. M., Briand, L., Guéguen, J., Popineau, Y., Larré, C. and Haertlé, T. (1996). Recent advances in enzymatic modifications of food proteins for improving their functional properties. Mol. Nutr. Food Res. 40:177182.

Chobert, J. M., El-Zahar, K., Sitohy, M., Dalgalarrondo, M., Metro, F., Choiset, Y. and Haertle, T. (2005). Angiotensin I-converting-enzyme (ACE) inhibitory activity of tryptic peptides of ovine $\beta$-lactoglobulin and of milk yoghurts obtained by using different starters. Le Lait Dairy Sci. Tech. 85:141-152.

Chobert, J. M., Sitohy, M. Z. and Whitaker, J. R. (1988a). Solubility and emulsifying properties of caseins modified enzymatically by Staphylococcus aureus V8 protease. J. Agr. Food Chem. 36:220-224.

Choi, Y. J., Hur, S., Choi, B. D., Konno, K. and Park, J. W. (2009). Enzymatic hydrolysis of recovered protein from frozen small croaker and functional properties of its hydrolysates. J. Food Sci. 74:C17-C24.

Claustre, J., Toumi, F., Trompette, A., Jourdan, G., Guignard, H., Chayvialle, J. A. and Plaisancie, P. (2002). Effects of peptides derived from dietary proteins on mucus secretion in rat jejunum. Am. J. Physiol. Gastrointest Liver Physiol. 283:521-528.

Clemente, A., Vioque, J., Sanchez-Vioque, R., Pedroche, J. and Millan, F. (1999). Production of Extensive Chickpea (Cicer arietinum L.) protein hydrolysates with reduced antigenic activity. J. Agr. Food Chem. 47:3776-3781.

Cole, A. M., Weis, P. and Diamond, G. (1997). Isolation and characterization of pleurocidin, an antimicrobial peptide in the skin secretions of winter flounder. J. Biol. Chem. 272:12008-12013.

Conlon, J. M., Mechkarska, M., Lukic, M. L. and Flatt, P. R. (2014a). Potential therapeutic applications of multifunctional host-defense peptides from frog skin as anti-cancer, anti-viral, immunomodulatory, and antidiabetic agents. Peptides. 57:67-77.

Conlon, J. M., Mechkarska, M., Radosavljevic, G., Attoub, S., King, J. D., Lukic, M. L. and McClean, S. (2014b). A family of antimicrobial and immunomodulatory peptides related to the frenatins from skin secretions of the Orinoco lime frog Sphaenorhynchus lacteus (Hylidae). Peptides. 56:132-40.
Corfield, A. P., Myerscough, N., Longman, R., Sylvester, P., Arul, S. and Pinatelli, M. (2000). Mucins and mucosal protection in the in the gastrointestinal Tract: new prospects for mucins in the pathology of gastrointestinal disease. Gut. 47:589-594.

Coscueta, E. R., Amorim, M. M., Voss, G. B., Nerli, B. B., Pico, G. A. and Pintado, M. E. (2016). Bioactive properties of peptides obtained from argentinian defatted soy flour protein by Corolase PP hydrolysis. Food Chem. 198:36-44.

Cudennec, B., Ravallec-Plé, R., Courois, E. and Fouchereau-Peron, M (2008). Peptides from fish and crustacean by-products hydrolysates stimulate cholecystokinin release in STC-1 cells. Food Chem. 111:970975.

Cuthbertson, B. J., Shepard, E. F., Chapman, R. W. and Gross, P. S. (2002) Diversity of the penaeidin antimicrobial peptides in two shrimp species. Immunogenetics. 54:442-445.

Da Silva Vaz, B., Moreira, J. B., Greque de Morais, M. and Alberto Vieira Costa, J. (2016). Microalgae as a new source of bioactive compounds in food supplements. Curr. Opin. Food Sci. 7:73-77.

Dallas, D. C., Citerne, F., Tian, T., Silva, V. L. M., Kalanetra, K. M., Frese, S A., Robinson, R. C., Mills, D. A. and Barile, D. (2016). Peptidomic analysis reveals proteolytic activity of kefir microorganisms on bovine milk proteins. Food Chem. 197:273-284.

Dallas, D. C., Guerrero, A., Parker, E. A., Robinson, R. C., Gan, J., German J. B., Barile, D. and Lebrilla, C. B. (2015). Current peptidomics: Applications, purification, identification, quantification, and functional analysis. Proteomics. 15:1026-1038.

Daskaya-Dikmen, C., Yucetepe, A., Karbancioglu-Guler, F., Daskaya, H and Ozcelik, B. (2017). Angiotensin-I-converting enzyme (ACE)-inhibitory peptides from plants. Nutrients. 9(316):1-19.

Daoud, R., Dubois, V., Bors-Dodita, L., Nedjar-Arroume, N., Krier, F., Chihib, N. E., Mary, P., Kouach, M., Briand, G. and Guillochon, D. (2005). New antibacterial peptide derived from bovine hemoglobin. Peptides. 26:713-719.

De Gobba, C., Tompa, G. and Otte, J. (2014a). Bioactive peptides from caseins released by cold active proteolytic enzymes from arsukibacterium ikkense. Food Chem. 165:205-215.

De Gobba, C., Espejo-Carpio, F. J., Skibsted, L. H. and Otte, J. (2014b). Antioxidant peptides from goat milk protein fractions hydrolysed by two commercial proteases. Int. Dairy J. 39:28-40.

De la Hoz, L., Ponezi, A. N., Milani, R. F., Nunes da Silva, V. S., De Souza, A. S. and Bertoldo-Pacheco, M. T. (2014). Iron-binding properties of sugar cane yeast peptides. Food Chem. 142:166-169.

De Vuyst, L. and Leroy, F. (2007). Bacteriocins from lactic acid bacteria: production, purification, and food applications. J. Mol. Microbiol. Biotechnol. 13:194-199.

Destoumieux, D., Munoz, M., Bulet, P. and Bachere, E. (2000). Penaeidins, a family of antimicrobial peptides from penaeid shrimp (Crustacea, Decapoda). Cell. Mol. Life Sci. 57:1260-1271.

Destoumieux, D., Bulet, P., Strub, J. M., Dorsselaer, A. V. and Bachere, E (1991). Recombinant expression and range of activity of penaeidins, antimicrobial peptides from penaeid shrimp. Eur. J. Biochem. 266:335346.

Destoumieux-Garzon, D., Saulnier, D., Garnier, J., Jouffrey, C., Bulet, P and Bachere, E. (2001). Antifungal peptides are generated from the $C$ terminus of shrimp hemocyanin in response to microbial challenge. $J$. Biol. Chem. 276:47070-47077.

Ding, Y., Liu, X., Bu, L., Li, H. and Zhang, S. (2012). Antimicrobial-immunomodulatory activities of zebrafish phosvitin-derived peptide Pt5. Peptides. 37:309-313.

Doucet, D., Gauthier, S. F. and Foegeding, E. A. (2001). Rheological characterization of a gel formed during extensive enzymatic hydrolysis. $J$. Food Sci. 66:711-715.

Doyen, A., Udenigwe, C. C., Mitchell, P. L., Marette, A., Aluko, R. E. and Bazinet, L. (2014). Anti-diabetic and antihypertensive activities of two flaxseed protein hydrolysate fractions revealed following their simultaneous separation by electrodialysis with ultrafiltration membranes. Food Chem. 145:66-76.

Eckert, E., Bamdad, F. and Chen, L. (2014). Metal solubility enhancing peptides derived from barley protein. Food Chem. 159:498-506. 
Ehlers, P. I., Nurmi, L., Turpeinen, A. M., Korpela, R. and Vapaatalo, H. (2011). Casein-derived tripeptide Ile-Pro-Pro improves angiotensin(1-7)- and bradykinin-induced rat mesenteric artery relaxation. Life Sci. 88:206-211.

El Hatmi, H., Jrad, Z., Khorchani, T., Jardin, J., Poirson, C., Perrin, C., Cakir-Kiefer, C. and Girardet, J. M. (2016). Identification of bioactive peptides derived from caseins, glycosylation-dependent cell adhesion molecule-1 (GlyCAM-1), and peptidoglycan recognition protein-1 (PGRP-1) in fermented camel milk. Int. Dairy J. 56:159-168.

El-Salam, M. H. A. and El-Shibiny, S. (2013). Bioactive peptides of buffalo, camel, goat, sheep, mare, and yak milks and milk products. Food Rev. Int. 29:1-23.

Elavarasan, K., Shamasundar, B. A., Badii, F. and Howell, N. (2016). Angiotensin I-converting enzyme (ACE) inhibitory activity and structural properties of oven- and freeze-dried protein hydrolysate from fresh water fish (Cirrhinus mrigala). Food Chem. 206:210-216.

Elfahri, K. R., Donkor, O. N. and Vasiljevic, T. (2014). Potential of novel lactobacillus helveticus strains and their cell wall bound proteases to release physiologically active peptides from milk proteins. Int. Dairy J. 38:37-46.

Elfahri, K. R., Vasiljevic, T., Yeager, T. and Donkor, O. N. (2016). Anticolon cancer and antioxidant activities of bovine skim milk fermented by selected Lactobacillus helveticus strains. J. Dairy Sci. 99:31-40.

Escudero, E., Mora, L., Fraser, P. D., Aristoy, M. C. and Toldra, F. (2013). Identification of novel antioxidant peptides generated in Spanish drycured ham. Food Chem. 138:1282-1288.

Escudero, E., Sentandreu, M. A., Arihara, K. and Toldra, F. (2010). Angiotensin I-Converting enzyme inhibitory peptides generated from in vitro gastrointestinal digestion of pork meat. J. Agr. Food Chem. 58:28952901.

Escudero, E., Toldra, F., Sentandreu, M. A., Nishimura, H. and Arihara, K. (2012). Antihypertensive activity of peptides identified in the in vitro gastrointestinal digest of pork meat. Meat Sci. 91:382-384.

Espeche Turbay, M. B., de Moreno de LeBlanc, A., Perdigón, G., Savoy de Giori, G. and Hebert, E. M. (2012). $\beta$-casein hydrolysate generated by the cell envelope-associated proteinase of Lactobacillus delbrueckii ssp. lactis CRL 581 protects against trinitrobenzene sulfonic acid-induced colitis in mice. J. Dairy Sci. 95:1108-1118.

Espejo-Carpio, F. J., De Gobba, C., Guadix, A., Guadix, E. M. and Otte, J. (2013). Angiotensin I-converting enzyme in hibitory activity of enzymatic hydrolysates of goat milk protein fractions. Int. Dairy J. 32:175-183.

Espejo-Carpio, F. J., Guadix, A. and Guadix, E. M. (2014a). Spray drying of goat milk protein hydrolysates with angiotensin converting enzyme inhibitory activity. Food Bioprocess Tech. 7:2388-2396.

Espejo-Carpio, F. J., Pérez-Gálvez, R., Del Carmen Almécija, M., Guadix, A. and Guadix, E. M. (2014b). Production of goat milk protein hydrolysate enriched in ACE-inhibitory peptides by ultrafiltration. J. Dairy Res. 81:385-393.

Esteve, C., Marina, M. L. and Garcia, M. C. (2015). Novel strategy for the revalorization of olive (Olea europaea) residues based on the extraction of bioactive peptides. Food Chem. 167:272-280.

Estrada-Salas, P. A., Montero-Moran, G. M., Martínez-Cuevas, P. P., Gonzalez, C. and Barba de la Rosa, A. P. (2014). Characterization of antidiabetic and antihypertensive properties of canary seed (Phalaris canariensis L.) peptides. J. Agr. Food Chem. 62:427-433.

Ewart, H. S., Dennis, D., Potvin, M., Tiller, C. and Fang, L. H. (2009). Development of a salmon protein hydrolysate that lowers blood pressure. Eur. Food Res. Technol. 229:561-569.

Fahmi, A., Morimura, S., Guo, H. C., Shigematsu, T., Kida, K. and Uemura, Y. (2004). Production of angiotensin I converting enzyme inhibitory peptides from sea bream scales. Process Biochem. 39:1195-1200.

Fan, X., Subramaniam, R., Weiss, M. F. and Monnier, V. M. (2003). Methylglyoxal-bovine serum albumin stimulates tumor necrosis factor alpha secretion in RAW 264.7 cells through activation of mitogen-activating protein kinase, nuclear factor $\mathrm{jB}$ and intracellular reactive oxygen species formation. Arch. Biochem. Biophys. 409:274-286.

Farvin, S. K. H., Andersen, L. L., Nielsen, H. H., Jacobsen, C., Jakobsen, G., Johansson, I. and Jessen, F. (2014). Antioxidant activity of cod (Gadus morhua) protein hydrolysates: In vitro assays and evaluation in 5\% fish oil-in-water emulsion. Food Chem. 149:326-334.
Favaro-Trindade, C. S., Santana, A. S., Monterrey-Quintero, E. S., Trindade, M. A. and Netto, F. M. (2010). The use of spray drying technology to reduce bitter taste of casein hydrolysate. Food Hydrocoll. 24:336-340.

Feng, X. L., Liu, Q. T., Cao, R. B., Zhou, B., Zhang, Y. P., Liu, K., Liu, X. D., Wei, J. C., Li, X. F. and Chen, P. Y. (2012). Characterization and immunomodulatory function comparison of various bursal-derived peptides isolated from the humoral central immune organ. Peptides. 33:258264.

Fernandez-Musoles, R., Castello-Ruiz, M., Arce, C., Manzanares, P., Ivorra, M. D. and Salom, J. B. (2014). Antihypertensive mechanism of lactoferrin-derived peptides: angiotensin receptor blocking effect. J. Agr. Food Chem. 62:173-181.

Fields, K., Falla, T. J., Rodan, K. and Bush, L. (2009). Bioactive peptides: signaling the future. J. Cosmet Dermatol. 8:8-13.

Fitzgerald, C., Mora-Soler, L., Gallagher, E., O'Connor, P., Prieto, J., SolerVila, A. and Hayes, M. (2012). Isolation and characterization of bioactive pro-peptides with in vitro renin inhibitory activities from the macroalga palmaria palmata. J. Agr. Food Chem. 60:7421-7427.

FitzGerald, R. J. and O'Cuinn, G. (2006). Enzymatic debittering of food protein hydrolysates. Biotechnol. Adv. 24:234-237.

Fogaca, A. C., Da Silva, P. I., Miranda, M. T. M., Bianchi, A. G., Miranda, A., Ribolla, P. E. M. and Daffre, S. (1999). Antimicrobial activity of a bovine hemoglobin fragment in the tick boophilus microplus. J. Biol. Chem. 274:25330-25334.

Froidevaux, R., Krier, F., Nedjar-Arroume, N., Vercaigne-Marko, D., Kosciarz, E., Ruckebusch, C., Dhulster, P. and Guillochon, D. (2001). Antibacterial activity of a pepsin-derived bovine hemoglobin fragment. FEBS Lett. 491:159-163.

Fujita, H., Suganuma, H., Usui, H., Kurahashi, K., Nakagiri, R., Sasaki, R. and Yoshikawa, M. (1996). Vasorela.xation by casomokinin L, a derivative of O-casobmorphin and casoxin D, is mediated by NK1 receptor Peptides. 17:635-639.

Fujita, H. and Yoshikawa, M. (1999). LKPNM: a prodrug-type ACEinhibitory peptide derived from fish protein. Immunopharm. 44:123-127.

Fujita, H., Yokoyama, K. and Yoshikawa, M. (2000). Classification and antihypertensive activity of angiotensin I-converting enzyme inhibitory peptides derived from food proteins. J. Food Sci. 65:546-569.

Fuke, Y., Sekiguchi, M. and Matsuoka, H. (1985). Nature of stem bromelain treatments on the aggregation and gelation of soybean proteins. $J$. Food Sci. 50:1283-1288.

Fukudome, S. and Yoshikawa, M. (1993). A novel opioid peptide derived from wheat gluten. FEBS Lett. 316:17-19.

García-Moreno, P. J., Pérez-Gálvez, R., Guadix, E. M. and Guadix, A. (2010). Recent patents on the upgrading of fish by-products. Recent Pat. Chem. Eng. 3:149-162.

García-Moreno, P. J., Batista, I., Pires, C., Bandarra, N. M., Espejo-Carpio, F. J., Guadix, A. and Guadix, E. M. (2014). Antioxidant activity of protein hydrolysates obtained from discarded mediterranean fish species. Food Res. Int. 65:469-476.

García-Moreno, P. J., Espejo-Carpio, F. J., Guadix, A. and Guadix, E. M. (2015). Production and identification of angiotensin I-converting enzyme (ACE) inhibitory peptides from mediterranean fish discards. $J$. Funct. Foods. 18:95-105.

García-Moreno, P. J., Guadix, A., Guadix, E. M. and Jacobsen, C. (2016). Physical and oxidative stability of fish oil-in-water emulsions stabilized with fish protein hydrolysates. Food Chem. 203:124-135.

García-Moreno, P. J., Pérez-Gálvez, R., Espejo-Carpio, F. J., Ruiz-Quesada, C., Pérez-Morilla, A. I., Martínez-Agustín, O., Guadix, A. and Guadix, E. M. (2016). Functional, bioactive and antigenicity properties of blue whiting protein hydrolysates: Effect of enzymatic treatment and degree of hydrolysis. J Sci. Food Agric. 97:299-308.

Gbogouri, G. A., Linder, M., Fanni, J. and Parmentier, M. (2004). Influence of hydrolysis degree on the functional properties of salmon byproducts hydrolysates. J. Food Sci. 69:615-622.

Geirsdottir, M., Sigurgisladottir, S., Hamaguchi, P. Y., Thorkelsson, G., Johannsson, R., Kristinsson, H. G. and Kristjansson, M. M. (2011). Enzymatic hydrolysis of Blue whiting (Micromesistius poutassou); functional and bioactive properties. J. Food Sci. 76:C14-C20. 
Ghelichi, S., Moltke Sørensen, A. D., García-Moreno, P. J., Hajfathalian, M. and Jacobsen, C. (2017). Physical and oxidative stability of fish oil-inwater emulsions fortified with enzymatic hydrolysates from common carp (Cyprinus carpio) roe. Food Chem. 237:1048-1057.

Girgih, A. T., He, R., Malomo, S., Offengenden, M., Wu, J. and Aluko, R. E. (2014). Structural and functional characterization of hemp seed (Cannabis sativa L.) protein-derived antioxidant and antihypertensive peptides. J. Funct. Foods. 6:384-394.

Goldberg, J., Shrikant, P. and Mescher, M. F. (2003). In vivo augmentation of tumor-specific CTL responses by class I/Peptide antigen complexes on microspheres (Large Multivalent Immunogen). J. Immunol. 170:228-235.

Gong, M., Mohan, A., Gibson, A. and Udenigwe, C. C. (2015). Mechanisms of plastein formation, and prospective food and nutraceutical applications of the peptide aggregates. Biotechnol. Rep. 5:63-69.

González-García, E., Marina, M. L. and Garcia, M. C. (2014). Plum (Prunus Domestica L.) by-product as a new and cheap source of bioactive peptides: Extraction method and peptides characterization. J. Funct. Foods. 11:428-437.

Grienke, U., Silke, J. and Tasdemir, D. (2014). Bioactive compounds from marine mussels and their effects on human health. Food Chem. 142:48-60.

Gu, Y. and Wu, J. (2013). LC-MS/MS coupled with QSAR modeling in characterising of angiotensin I-converting enzyme inhibitory peptides from soybean proteins. Food Chem. 141:2682-2690.

Guerard, F. (2006). Enzymatic methods for marine by-products recovery. In: Maximising the Value of Marine by-Products, pp. 107-143. Shahidi, F. Ed., Woodhead Publishing Limited, Cambridge.

Guzel-Seydim, Z. B., Kok-Tas, T., Greene, A. K. and Seydim, A. C. (2011). Review: functional properties of kefir. Crit. Rev. Food Sci. 51:261-268.

Hai-Lun, H., Xiu-Lan, C., Cai-Yun, S., Yu-Zhong, Z. and Bai-Cheng, Z. (2006). Analysis of novel angiotensin-I-converting enzyme inhibitory peptides from protease-hydrolyzed marine shrimp Acetes chinensis. J. Peptide Sci. 12:726-733.

Halldorsdottir, S. M., Kristinsson, H. G., Sveinsdottir, H., Thorkelsson, G. and Hamaguchi, P. Y. (2013). The effect of natural antioxidants on haemoglobin-mediated lipid oxidation during enzymatic hydrolysis of cod protein. Food Chem. 141:914-919.

Harnedy, P. A. and FitzGerald, R. J. (2012). Bioactive peptides from marine processing waste and shellfish: A review. J. Funct. Foods. 4:6-24.

Hartmann, R. and Meisel, H. (2007). Food-derived peptides with biological activity from research to food applications. Curr. Opin. Biotech. 18:163-169.

Hayashida, K., Takeuchi, T., Shimizu, H., Ando, K. and Harada, E. (2003). Novel function of bovine milk-derived lactoferrin on antinociception mediated by m-opioid receptor in the rat spinal cord. Brain Res. 965:239-245.

Hayes, M., Ross, R. P., Fitzgerald, G. F., Hill, C. and Stanton, C. (2006). Casein-derived antimicrobial peptides generated by lactobacillus acidophilus DPC6026. Appl. Environ. Microbial. 72:2260-2264.

He, R., Girgih, A. T., Rozoy, E., Bazinet, L., Ju, X. and Aluko, R. E. (2016). Selective separation and concentration of antihypertensive peptides from rapeseed protein hydrolysate by electrodialysis with ultrafiltration membranes. Food Chem. 197:1008-1014.

Hernandez-Ledesma, B., Amigo, L., Ramos, M. and Recio, I. (2004). Application of high-performance liquid chromatography-tandem mass spectrometry to the identification of biologically active peptides produced Abstract by milk fermentation and simulated gastrointestinal digestion. J. Chromatogr A. 1049:107-114.

Hernández-Ledesma, B., García-Nebot, M. J., Fernández-Tomé, S., Amigo, L. and Recio, I. (2014). Dairy protein hydrolysates: Peptides for health benefits. Int. Dairy J. 38:82-100.

Hernandez-Ledesma, B., Quiros, A., Amigo, L. and Recio, I. (2007). Identification of bioactive peptides after digestion of human milk and infant formula with pepsin and pancreatin. Int. Dairy J. 17:42-49.

Hwang, C., Chen, Y., Luo, C. and Chiang, W. (2016). Antioxidant and antibacterial activities of peptide fractions from flaxseed protein hydrolysed by protease from bacillus altitudinis HK02. Int. J. Food Sci. Technol. 51:681-689.

Horiguchi, N., Horiguchi, H. and Suzuki, Y. (2005). Effect of wheat gluten hydrolysate on the immune system in healthy human subjects. Biosci. Biotechnol. Biochem. 69:2445-2449.

Hou, H., Li, B., Zhao, X., Zhang, Z. and Li, P. (2011). Optimization of enzymatic hydrolysis of Alaska pollock frame for preparing protein hydrolysates with low-bitterness. Food Sci. Technol. 44:421-428.

Hsu, K. C. (2010). Purification of antioxidative peptides prepared from enzymatic hydrolysates of tuna dark muscle by-product. Food Chem. 122:42-48

Hsu, K. C., Li-Chan, E. C. Y. and Jao, C. L. (2011). Antiproliferative activity of peptides prepared from enzymatic hydrolysates of tuna dark muscle on human breast cancer cell line MCF-7. Food Chem. 126:617-622.

Hu, J., Xu, M., Hang, B., Wang, L., Wang, Q., Chen, J., Song, T., Fu, D., Wang, Z., Wang, S. and Liu, X. (2011). Isolation and characterization of an antimicrobial peptide from bovine hemoglobin a-subunit. World J. Microbiol. Biotechnol. 27:767-771.

Huang, B. B., Lin, H. C. and Chang, Y. W. (2015a). Analysis of proteins and potential bioactive peptides from tilapia (Oreochromis spp) processing co-products using proteomic techniques coupled with BIOPEP database. J. Funct. Foods. 19:629-640.

Huang, C. Y., Wu, C. H., Yang, J. I. and Li, Y. H. (2015b). Evaluation of iron-binding activity of collagen peptides prepared from the scales of four cultivated fishes in Taiwan. J. Food Drug Anal. 23:671-678.

Huang, G., Ren, L. and Jiang, J. (2011). Purification of a histidine-containing peptide with calcium binding activity from shrimp processing byproducts hydrolysate. Eur. Food Res. Technol. 232:281-287.

Huang, P., Tunis, J., Parry, C., Tallarida, R. and Liu-Chen, L. Y. (2016) Synergistic antidepressant-like effects between a kappa opioid antagonist (LY2444296) and a delta opioid agonist (ADL5859) in the mouse forced swim test. Eur. J. Pharmacol. 781:53-59.

Huang, W., Chakrabarti, S., Majumder, K., Jiang, Y., Davidge, S. T. and $\mathrm{Wu}$, J. (2010). Egg-derived peptide IRW inhibits TNF-r-induced inflammatory response and oxidative stress in endothelial cells. J. Agr. Food Chem. 58:10840-10846.

Hunter, H. N., Demcoe, A. R., Jenssen, H., Gutteberg, T. I. and Vogel, H. J. (2005). Human lactoferricin is partially folded in aqueous solution and is better stabilized in a membrane mimetic solvent. Antimicrob Agents Chemother. 49:3387-3395.

Ibrahim, S. A. and Bezkorovainy, A. (1994). Growth-promoting factors for Bifidobacterium longum. J. Food Sci. 59:189-191.

Ishibashi, N., Kouge, K., Shinoda, I., Kanehisa, H. and Okai, H. (1988) Biochemistry of food proteins. Agr. Biol. Chem. 52:819-827.

Jahangiri, R., Soltani, S. and Barzegar, A. (2014). A review of QSAR studies to predict activity of ACE peptide inhibitors. Pharm. Sci. 20(3):122-129.

Jain, S. and Kumar Anal, A. (2017). Production and characterization of functional properties of protein hydrolysates from egg shell membranes by lactic acid bacteria fermentation. J. Food Sci. Technol. 54:1062-1072.

Jang, A., Jo, C., Kang, K. S. and Lee, M. (2008). Antimicrobial and human cancer cell cytotoxic effect of synthetic angiotensin-converting enzyme (ACE) inhibitory peptides. Food Chem. 107:327-336.

Jang, A. and Lee, M. (2005). Purification and identification of angiotensin converting enzyme inhibitory peptides from beef hydrolysates. Meat Sci. 69:653-661.

Jauhiainen, T., Ronnback, M., Vapaatalo, H., Wuolle, K., Kautiainen, H., Groop, P. H. and Korpela, R. (2010). Long-term intervention with lactobacillus helveticus fermented milk reduces augmentation index in hypertensive subjects. Eur. J. Clin. Nutr. 64:424-431.

Je, J. Y., Park, J. Y., Jung, W. K., Park, P. J. and Kim, S. K. (2005a). Isolation of angiotensin I converting enzyme (ACE) inhibitor from fermented oyster sauce, Crassostrea gigas. Food Chem. 90:809-814.

Je, J. Y., Park, P. J., Byun, H. G., Jung, W. K. and Kim, S. K. (2005b). Angiotensin I converting enzyme (ACE) inhibitory peptide derived from the sauce of fermented blue mussel, Mytilus edulis. Bioresource Technol. 96:1624-1629.

Je, J. Y., Park, P. J. and Kim, S. K. (2005c). Antioxidant activity of a peptide isolated from Alaska pollack (Theragra chalcogramma) frame protein hydrolysate. Food Res. Int. 38:45-50. 
Je, J. Y., Lee, K. H., Lee, M. H. and Ahn, C. B. (2009). Antioxidant and antihypertensive protein hydrolysates produced from tuna liver by enzymatic hydrolysis. Food Res. Int. 42:1266-1272.

Jeewanthi, R. K. C., Lee, N. K. and Paik, H. D. (2015). Improved functional characteristics of whey protein hydrolysates in food industry. Korean J. Food Sci. An. 35:350-359.

Jemil, I., Jridi, M., Nasri, R., Ktari, N., Ben Slama-Ben Salem, R., Mehiri, M., Hajji, M. and Nasri, M. (2014). Functional, antioxidant and antibacterial properties of protein hydrolysates prepared from fish meat fermented by Bacillus subtilis A26. Process Biochem. 49:963-972.

Jemil, I., Mora, L., Nasri, R., Abdelhedi, O., Aristoy, M. C., Hajji, M., Nasri, M. and Toldra, F. (2016). A peptidomic approach for the identification of antioxidant and ACE-inhibitory peptides in sardinelle protein hydrolysates fermented by Bacillus subtilis A26 and Bacillus amyloliquefaciens An6. Food Res. Int. 89:347-358.

Jeon, Y. J., Byun, H. G. and Kim, S. K. (1999). Improvement of functional properties of cod frame protein hydrolysates using ultrafiltration membranes. Process Biochem. 35:471-478.

Jiang, Z., Tian, B., Brodcrob, A. and Huo, G. (2010). Production, analysis and in vivo evaluation of novel angiotensin-I-converting enzyme inhibitory peptides from bovine casein. Food Chem. 123:779-786.

Jo, H. Y., Jung, W. K. and Kim, S. K. (2008). Purification and characterization of a novel anticoagulant peptide from marine echiuroid worm, Urechis unicinctus. Process Biochem. 43:179-184.

Jolles, P., Levy-Toledano, S., Fiat, A. M., Soria, C., Gillessen, D., Thomaidis, A., Dunn, F. W. and Caen, J. P. (1986). Analogy between fibrinogen and casein Effect of an undecapeptide isolated from rc-casein on platelet function. Eur. J. Biochem. 158:379-382.

Ju, Z. Y., Otte, J., Madsen, J. S. and Qvist, K. B. (1995). Effects of limited proteolysis on gelation and gel properties of whey protein isolate. $J$. Dairy Sci. 78:2119-2128.

Juillerat-Jeanneret, L., Robert, M. C. and Juillerat, M. A. (2011). Peptides from Lactobacillus hydrolysates of bovine milk caseins inhibit prolylpeptidases of human colon cells. J. Agr. Food Chem. 59:370-377.

Jung, W. K., Jo, H. Y., Qian, Z. J., Jeong, Y. J., Park, S. G., Choi, I. W. and Kim, S. K. (2007). A novel anticoagulant protein with high affinity to blood coagulation factor Va from Tegillarca granosa. J. Biochem. Mol. Biol. 40:832-838.

Jung, W. K. and Kim, S. K. (2007). Calcium-binding peptide derived from pepsinolytic hydrolysates of hoki (Johnius belengerii) frame. Eur. Food Res. Technol. 224:763-767.

Jung, W. K. and Kim, S. K. (2009). Isolation and characterisation of an anticoagulant oligopeptide from blue mussel, Mytilus edulis. Food Chem. 117:687-692.

Jung, W. K., Mendis, E., Je, J. Y., Park, P. J., Son, B. W., Kim, H. C., Choi, Y. K. and Kim, S. K. (2006). Angiotensin I-converting enzyme inhibitory peptide from yellowfin sole (Limanda aspera) frame protein and its antihypertensive effect in spontaneously hypertensive rats. Food Chem. 94:26-32.

Kadam, S. U., Tiwari, B. K., Alvarez, C. and O'Donnell, C. P. (2015). Ultrasound applications for the extraction, identification and delivery of food proteins and bioactive peptides. Trends Food Sci. Tech. 46:60-67.

Kagawa, K., Matsutaka, H., Fukuhama, C., Fujino, H. and Okuda, H. (1998). Suppressive effect of globin digest on postprandial hyperlipidemia in male volunteers. J. Nutr. 128(1):56-60.

Kamal, M. and Motohiro, T. (1986). Effect of $\mathrm{pH}$ and metal ions on the fungicidal action of salmine sulfate. B Jpn. Soc. Sci. Fish. 52:1843-1846.

Kamemori, N., Takeuchi, T., Hayashida, K. and Harada, E. (2004). Suppressive effects of milk-derived lactoferrin on psychological stress in adult rats. Brain Res. 1029:34-40.

Kampa, M., Bakogeorgou, E., Hatzoglou, A., Damianaki, A., Martin, P. M. and Castanas, E. (1997). Opioid alkaloids and casomorphin peptides decrease the proliferation of prostatic cancer cell lines) LNCaP, PC3 and DU145) through a partial interaction with opioid receptors. Eur. J. Pharm. 335:255-265.

Kampa, M., Loukas, S., Hatzoglou, A., Martin, P. and Martin, P. M. (1996). Identification of a novel opioid peptide (Tyr-Val-Pro-Phe-Pro) derived from human aS1 casein (aS1-casomorphin, and aS1-casomorphin amide). Biochem J. 319:903-908.
Kannan, A., Hettiarachchy, N. S., Marshall, M., Raghavan, S. and Kristinsson, H. (2011). Shrimp shell peptide hydrolysates inhibit human cancer cell proliferation. J. Sci. Food Agr. 91:1920-1924.

Katano, S., Oki, T., Matsuo, Y., Yoshihira, K., Nara, Y., Miki, T., Matsui, T. and Matsumoto, K. (2003). Antihypertensive effect of alkaline protease hydrolysate of the pearl oyster Pinctada fucatamartensii and separation and identification of angiotensin-I converting enzyme inhibitory peptides. Nippon Suisan Gakk. 69:975-980.

Katayama, K., Anggraeni, H. E., Mori, T., Ahhmed, A. M., Kawahara, S., Sugiyama, M., Nakayama, T., Maruyama, M. and Muguruma, M. (2008). Porcine skeletal muscle troponin is a good source of peptides with angiotensin-I converting enzyme inhibitory activity and antihypertensive effects in spontaneously hypertensive rats. J. Agr. Food Chem. 56:355-360.

Katayama, K., Mori, J. T., Kawahara, S., Miake, K., Kodama, Y., Sugiyama, M., Kawamura, Y., Nakayama, T., Maruyama, M. and Muguruma, M. (2007). Angiotensin-I converting enzyme inhibitory peptide derived from porcine skeletal muscle myosin and its antihypertensive activity in spontaneously hypertensive rats. J. Food Sci. 72:S702-S706.

Katayama, K., Tomatsu, M., Fuchu, H., Sugiyama, M., Kawahara, S., Yamauchi, K., Kawamura, Y. and Muguruma, M. (2003). Purification and characterization of an angiotensin I-converting enzyme inhibitory peptide derived from porcine troponin C. Anim Sci. J. 74:53-58.

Kawabata, S. I., Nagayama, R., Hirata, M., Shigenaga, T., Agarwala, K. L., Saito, T., Cho, J., Nakajima, H., Takagi, T. and Iwanaga, S. (1996) Tachycitin, a small granular component in horseshoe crab hemocytes, is an antimicrobial protein with chitin-binding activity. J. Biochem. 120:1253-1260.

Kawamura, Y., Takane, T., Satake, M. and Sugimoto, T. (1992). Physiologically active peptide motif in proteins: Peptide inhibitors of ACE from the hydrolysates of antarctic krill muscle protein. Japan Agr. Res. Quart. 26:210-213.

Kawasaki, T., Seki, E., Osajima, K., Yoshida, M., Asada, K., Matsui, T. and Osajima, Y. (2000). Antihypertensive effect of Valyl-Tyrosine, a short chain peptide derived from sardine muscle hydrolysate, on mild hypertensive subjects. J. Hum. Hypertens. 14:519-523.

Kim, E. K., Lee, S. J., Jeon, B. T., Moon, S. H., Kim, B., Park, T. K., Han, J. S. and Park, P. J. (2009). Purification and characterisation of antioxidative peptides from enzymatic hydrolysates of venison protein. Food Chem. 114:1365-1370.

Kim, S. E., Kim, H. H., Kim, J. Y., Kang, Y. I., Woo, H. J. and Lee, H. J. (2000). Anticancer activity of hydrophobic peptides from soy proteins. BioFactors. 12:151-155.

Kim, S. Y., Je, J. Y. and Kim, S. K. (2007). Purification and characterization of antioxidant peptide from hoki (Johnius belengerii) frame protein by gastrointestinal digestion. J. Nutr. Biochem. 18:31-38.

Kleekayai, T., Harnedy, P. A., O'Keeffe, M. B., Poyarkov, A. A., CunhaNeves, A., Suntornsuk, W. and FitzGerald, R. J. (2015). Extraction of antioxidant and ACE inhibitory peptides from Thai traditional fermented shrimp pastes. Food Chem. 176:441-447.

Klompong, V., Benjakul, S., Kantachote, D. and Shahidi, F. (2007). Antioxidative activity and functional properties of protein hydrolysate of yellow stripe trevally (Selaroides leptolepis) as influenced by the degree of hydrolysis and enzyme type. Food Chem. 102:1317-1327.

Kodera, T. and Nio, N. (2006). Identification of an angiotensin I-converting enzyme inhibitory peptides from protein hydrolysates by a soybean protease and the antihypertensive effects of hydrolysates in spontaneously hypertensive model rats. J. Food Sci. 71:C164-C173.

Kohmura, M., Nio, N. and Ariyoshi, Y. (1990). Inhibition of angiotensinconverting enzyme by synthetic peptide fragments of HumanK-Casein. Agr. Biol. Chem. 54:835-836.

Korhonen, H. (2009). Milk-derived bioactive peptides: From science to applications. J. Funct. Foods. 1:177-187.

Kostyra, E., Sienkiewicz-Szlapka, E., Jarmolowska, B., Krawczuk, S. and Kostyra, H. (2004). Opioid peptides derived from milk proteins. J. Food Nutr. Sci. 13:25-35.

Koyama, T., Noguchi, K., Aniya, Y. and Sakanashi, M. (1998). Analysis for sites of anticoagulant action of plancinin, a new anticoagulant peptide isolated from the starfish Acanthaster planci, in the blood coagulation cascade. Gen. Pharmac. 31:277-282. 
Kristinsson, H. G. and Rasco, B. A. (2000). Fish protein hydrolysates: Production, biochemical, and functional properties. Crit. Rev. Food Sci. 40:43-81.

Kristinsson, H. G. (2006). Aquatic food protein hydrolysates. In: Maximising the Value of Marine by-Products, pp. 229-248. Shahidi, F., Ed., Woodhead Publishing Limited, Cambridge.

Kuehler, C. A. and Stine, C. M. (1974). Effect of enzymatic hydrolysis on some functional properties of whey proteins. J. Food Sci. 39:379-382.

Kuipers, B. J. H., van Koningsveld, G. A., Alting, A. C., Driehuis, F., Gruppen, H. and Voragen, A. G. J. (2005). Enzymatic hydrolysis as a means of expanding the cold gelation conditions of soy proteins. J. Agr. Food Chem. 53:1031-1038.

Kumar Rai, A., Sanjukta, S., Chourasia, R., Bhat, I., Bhardwaj, P. K. and Sahoo, D. (2017). Production of bioactive hydrolysate using protease, $\beta$-glucosidase and $\alpha$-amylase of Bacillus spp. isolated from kinema. Bioresour Technol. 235:358-365.

Lacroix, I. M. E. and Li-Chan, E. C. Y. (2012). Evaluation of the potential of dietary proteins as precursors of dipeptidyl peptidase (DPP)-IV inhibitors by an in silico approach. J. Funct. Foods. 4(2):403-422.

Lafarga, T. and Hayes, M. (2016). Bioactive protein hydrolysates in the functional food ingredient industry: overcoming current challenges. Food Rev. Int. 33:217-246.

Lafarga, T., Aluko, R. E., Rai, D. K., O’Connor, P. and Hayes, M. (2016). Identification of bioactive peptides from a papain hydrolysate of bovine serum albumin and assessment of an antihypertensive effect in spontaneously hypertensive rats. Food Res. Int. 81:91-99.

Lam, S. K. and Ng, T. B. (2001). First simultaneous isolation of a ribosome inactivating protein and an antifungal protein from a mushroom (Lyophyllum shimeji) together with evidence for synergism of their antifungal effects. Arch. Biochem. Biophys. 393:271-280.

Lam, S. K. and Ng, T. B. (2013). Purification and characterization of an antifungal peptide with potent antifungal activity but devoid of antiproliferative and HIV reverse transcriptase activities from legumi secchi beans. Appl. Biochem. Biotechnol. 169:2165-2174.

Lammi, C., Zanoni, C. and Arnoldi, A. (2015). Three peptides from soy glycinin modulate glucose metabolism in human hepatic hepG2 Cells. Int. J. Mol. Sci. 16:27362-27370.

Langevin, M. E., Roblet, C., Moresoli, C., Ramassamy, C. and Bazinet, L. (2012). Comparative application of pressure- and electrically-driven membrane processes for isolation of bioactive peptides from soy protein hydrolysate. J. Membrane Sci. 403-404:15-24.

Lassoued, I., Mora, L., Barkia, A., Aristoy, M. C., Nasri, M. and Toldrá, F. (2015a). Bioactive peptides identified in thornback ray skin's gelatin hydrolysates by proteases from Bacillus subtilis and Bacillus amyloliquefaciens. J. Proteomics. 128:8-17.

Lassoued, I., Mora, L., Nasri, R., Jridi, M., Toldrá, F., Aristoy, M. and Nasri, M. (2015b). Characterization and comparative assessment of antioxidant and ACE inhibitory activities of thornback ray gelatin hydrolysates. J. Funct. Foods. 13:225-238.

Lauth, X., Shike, H., Burns, J. C., Westerman, M. E., Ostland, V. E., Carlberg, J. M., Van Olst, J. C., Nizet, V., Taylor, S. W. and Shimizu, C. (2002). Discovery and characterization of two isoforms of moronecidin, a novel antimicrobial peptide from hybrid striped bass. J. Biol. Chem. 277:5030-5039.

Le Maux, S., Nongonierma, A. B. and Fitzgerald, R. J. (2015). Improved short peptide identification using HILIC-MS/MS: Retention time prediction model based on the impact of amino acid position in the peptide sequence. Food Chem. 173:847-854.

Le Maux, S., Nongonierma, A. B., Barre, C. and Fitzgerald, R. J. (2016). Enzymatic generation of whey protein hydrolysates under $\mathrm{pH}$-controlled and non $\mathrm{pH}$-controlled conditions: Impact on physicochemical and bioactive properties. Food Chem. 199:246-251.

Lee, J. E., Bae, I. Y., Lee, H. G. and Yang, C. B. (2006a). Tyr-Pro-Lys, an angiotensin I-converting enzyme inhibitory peptide derived from broccoli (Brassica oleracea Italica). Food Chem. 99:143-148.

Lee, N. Y., Cheng, J. T., Enomoto, T. and Nakano, Y. (2006b). One peptide derived from hen ovotransferrin as pro-drug to inhibit angiotensin converting enzyme. J. Food Drug Anal. 14:31-35.

Lee, S. H. and Song, K. B. (2009a). Purification of an iron-binding nonapeptide from hydrolysates of porcine blood plasma protein. Process Biochem. 44:378-381.
Lee, S. H. and Song, K. B. (2009b). Isolation of a calcium-binding peptide from enzymatic hydrolysates of porcine blood plasma protein. $J$. Korean Soc. Appl. Biol. Chem. 52:290-294.

Lee, S. H., Qian, Z. J. and Kim, S. K. (2010). A novel angiotensin I converting enzyme inhibitory peptide from tuna frame protein hydrolysate and its antihypertensive effect in spontaneously hypertensive rats. Food Chem. 118:96-102.

Lee, S. W., Shimizu, M., Kaminogawa, S. and Yamauchi, K. (1987). Emulsifying properties of peptides obtained from hydrolysates of $\beta$-casein. Agric. Biol. Chem. 51:161-166.

Lee, S. Y., Lee, B. L. and Soderhall, K. (2002). Processing of an antibacterial peptide from hemocyanin of the freshwater crayfish Pacifastacus leniusculus. J. Biol. Chem. 278:7927-7933.

Lee, T. G. and Maruyama, S. (1998). Isolation of HIV-1 protease-inhibiting peptides from thermolysin hydrolysate of oyster proteins. Biochem. Bioph. Res. Co. 253:604-608.

Lee, Y. G., Kim, J. Y., Lee, K. W., Kim, K. H. and Lee, H. J. (2003). Peptides from anchovy sauce induce apoptosis in a human lymphoma cell (U937) through the increase of caspase- 3 and -8 activities. Ann. N.Y. Acad. Sci. 1010:399-404.

Lee, Y. G., Lee, K. W., Kim, J. Y., Kim, K. H. and Lee, H. J. (2004). Induction of apoptosis in a human lymphoma cell line by hydrophobic peptide fraction separated from anchovy sauce. BioFactors. 21:63-67.

Leung, E. H. W., Wang, J. H. and Ng, T. B. (2008). Concurrent purification of two defense proteins from French bean seeds: a defensin-like antifungal peptide and a hemagglutinin. J. Pept. Sci. 14:349-353.

Li, B., Chen, F., Wang, X., Ji, B. and Wu, Y. (2007). Isolation and identification of antioxidative peptides from porcine collagen hydrolysate by consecutive chromatography and electrospray ionization-mass spectrometry. Food Chem. 102:1135-1143.

Li-Chan, E. C. Y. (2015). Bioactive peptides and protein hydrolysates: research trends and challenges for application as nutraceuticals and functional food ingredients. Curr. Opin. Food Sci. 1:28-37.

Li-Chan, E. C. Y., Cheung, I. W. Y. and Byun, H. G. (2016). Shrimp (Pandalopsis dispar) waste hydrolysate as a source of novel $\beta$-secretase inhibitors. Fish Aquat Sci. 19:1-7.

Lin, F., Chen, L., Liang, R., Zhang, Z., Wang, J., Cai, M. and Li, Y. (2011). Pilot-scale production of low molecular weight peptides from corn wet milling byproducts and the antihypertensive effects in vivo and in vitro. Food Chem. 124:801-807.

Lin, H. M., Deng, S. G., Huang, S. B., Li, Y. J. and Song, R. (2015). The effect of ferrous-chelating hairtail peptides on iron deficiency and intestinal flora in rats. J. Sci. Food Agric. 96:2839-2844.

Lin, J. W., Jia, J., Shen, Y. H., Zhong, M., Chen, L. J., Li, H. G., Ma, H., Guo, Z F., Qi, M. F., Liu, L. X. and Li, T. L. (2013). Functional expression of FIPfve, a fungal immunomodulatory protein from the edible mushroom Flammulina velutipes in Pichia pastoris GS115. J. Biotechnol. 168:527-533.

Lin, K., Zhang, L., Han, X. and Cheng, D. (2017). Novel angiotensin I-converting enzyme inhibitory peptides from protease hydrolysates of qula casein: Quantitative structure-activity relationship modeling and molecular docking study. J. Funct. Foods. 32:266-277.

Lin, P., Wong, J. H. and Ng, T. B. (2010). A defensin with highly potent antipathogenic activities from the seeds of purple pole bean. Biosci. Rep. 30:101-109.

Linarès, E., Larré, C., Lemeste, M. and Popineau, Y. (2000). Emulsifying and foaming properties of gluten hydrolysates with an increasing degree of hydrolysis: role of soluble and insoluble fractions. Cereal. Chem. 77:414-420.

Linde, G. A., Junior, A. L., Faria, E. V., Colauto, N. B., Moraes, F. F. and Zanin, G. M. (2009). Taste modification of amino acids and protein hydrolysate by a-cyclodextrin. Food Res. Int. 42:814-818.

Liu, B. Y., Zhu, K. X., Peng, W., Guo, X. N. and Zhou, H. M. (2016). Effect of sequential hydrolysis with endo- and exo-peptidase on bitterness properties of wheat gluten hydrolysates. RSC $A d v$. 6:27659-27668.

Liu, J., Wang, S., Qi, J., Wang, X. and Song, Y. (1998). The immunostimulatory effect of bio-active peptide from pollen on murine and human lymphocytes. Mech. Ageing Dev. 104:125-132.

Liu, R., Wang, M., Duan, J., Guo, J. and Tang, Y. (2010). Purification and identification of three novel antioxidant peptides from Cornu bubali (water buffalo horn). Peptides. 31:786-793. 
Liu, R., Zheng, W., Li, J., Wang, L., Wu, H., Wang, X. and Shi, L. (2015). Rapid identification of bioactive peptides with antioxidant activity from the enzymatic hydrolysate of Mactra veneriformis by UHPLC-QTOF mass spectrometry. Food Chem. 167:484-489.

Liu, X., Jiang, D. and Peterson, D. G. (2014). Identification of bitter peptides in whey protein hydrolysate. J. Agric. Food Chem. 62:5719-5725.

Liu, Z., Dong, S., Xu, J., Zeng, M., Song, H. and Zhao, Y. (2008). Production of cysteine-rich antimicrobial peptide by digestion of oyster (Crassostrea gigas) with alcalase and bromelin. Food Control. 19:231-235.

Lo, H. Y., Li, C. C., Ho, T. Y. and Hsiang, C. Y. (2016). Identification of the bioactive and consensus peptide motif from Momordica charantia insulin receptor-binding protein. Food Chem. 204:298-305.

López-Cervantes, J., Sánchez-Machado, D. I. and Rosas-Rodríguez, J. A. (2006). Analysis of free amino acid in fermented shrimp waste by highperformance liquid chromatography. J. Chromatogr. A. 1105:106-110.

Luna-Vital, D. A., Mojica, L., González de Mejía, E., Mendoza, S. and Loarca-Piña, G. (2015). Biological potential of protein hydrolysates and peptides from common bean (Phaseolus vulgaris L.): A review. Food Res. Int. 76:39-50.

Ma, J. J., Mao, X. Y., Wang, Q., Yang, S., Zhang, D., Chen, S. W. and Li, Y. H. (2013). Effect of spray drying and freeze drying on the immunomodulatory activity, bitter taste and hygroscopicity of hydrolysate derived from whey protein concentrate. LWT - Food Sci. Technol. 56 (2):296-302.

Maeno, M., Yamamoto, N. and Takano, T. (1996). Identificication of an antihypertensive peptide from casein hydrolysate produced by a proteinase from Lactobacillus helveticus CP790. J. Dairy Sci. 79:1316-1321.

Madden, T., Tran, H. T., Beck, D., Huie, R., Newman, R. A., Pusztai, L., Wright, J. J. and Abbruzzese, J. L. (2000). Novel marine-derived anticancer agents: A phase I clinical, pharmacological, and pharmacodynamic study of dolastatin 10 (NSC 376128) in patients with advanced solid tumors. Clin. Canc. Res. 6:1293-1301.

Majumder, K., Chakrabarti, S., Davidge, S. T. and Wu, J. (2013a). Structure and activity study of egg protein ovotransferrin derived peptides (IRW and IQW) on endothelial inflammatory response and oxidative stress. J. Agr. Food Chem. 61:2120-2129.

Majumder, K., Chakrabarti, S., Morton, J. S., Panahi, S., Kaufman, S., Davidge, S. T. and Wu, J. (2013b). Egg-Derived Tri-Peptide IRW exerts antihypertensive effects in spontaneously hypertensive rats. PLoS One. 8(11):e82829.

Majumder, K., Chakrabarti, S., Morton, J. S., Panahi, S., Kaufman, S., Davidge, S. T. and Wu, J. (2015). Egg-derived ACE-inhibitory peptides IQW and LKP reduce blood pressure in spontaneously hypertensive rats. J. Funct Foods. 13:50-60.

Malaguti, M., Dinelli, G., Leoncini, E., Bregola, V., Bosi, S., Cicero, A. F. G. and Hrelia, S. (2014). Bioactive peptides in cereals and legumes: Agronomical, biochemical and clinical aspects. Int. J. Mol. Sci. 15:21120-21135.

Malvisi, M., Stuknyte, M., Magro, G., Minozzi, G., Giardini, A., Noni, I. D. and Piccinini, R. (2015). Antibacterial activity and immunomodulatory effects on a bovine mammary epithelial cell line exerted by nisin A-producing Lactococcus lactis strains. J. Dairy Sci. 99:2288-2296.

Meisel, H. (2005). Biochemical properties of peptides encrypted in bovine milk proteins. Curr. Med. Chem. 12:1905-1919.

Mercier, A., Gauthier, S. F. and Fliss, I. (2004). Immunomodulating effects of whey proteins and their enzymatic digests. Int. Dairy J. 14:175-183.

Miguel, M. and Aleixandre, A. (2006). Antihypertensive peptides derived from egg proteins. J. Nutr. 136(6):1457-1460.

Morimura, S., Nagata, H., Uemura, Y., Fahmi, A., Shigematsu, T. and Kida, K. (2002). Development of an effective process for utilization of collagen from livestock and fish waste. Process Biochem. 37:1403-1412.

Marques, M. R., Fontanari, G. G., Pimenta, D. C., Soares-Freitas, R. M. and Arêas, J. A. G. (2015). Proteolytic hydrolysis of cowpea proteins is able to release peptides with hypocholesterolemic activity. Food Res. Int. 77:43-48.

Martínez-Maqueda, D., Miralles, B., Cruz-Huerta, E. and Recio, I. (2013a). Casein hydrolysate and derived peptides stimulate mucin secretion and gene expression in human intestinal cells. Int. Dairy J. 32:13-19.

Martínez-Maqueda, D., Miralles, B., Ramos, M. and Recio, I. (2013b). Effect of $\beta$-lactoglobulin hydrolysate and $\beta$-lactorphin on intestinal mucin secretion and gene expression in human goblet cells. Food Res. Int. 54:1287-1291.

Maruyama, S., Mitachi, H., Tanaka, H., Tomizuka, N. and Suzuki, H. (1987). Studies on the active site and antihypertensive activity of angiotensin I-converting enzyme inhibitors derived from casein. Agr. Biol. Chem. 51:1581-1586.

Masuda, M., Nakashima, H., Ueda, T., Naba, H., Ikoma, R., Otaka, A., Terakawa, Y., Tamamura, H., Ibuka, T., Murakami, T., Koyanagi, Y., Waki, M., Matsumoto, A., Yamamoto, N., Funakoshi, S. and Fujiil, N. (1992). A novel anti-HIV synthetic peptide, T-22 ([TYR5,12, LYS']POLYPHEMUSIN II). Biochem. Bioph. Res. Co. 189:845-850.

Matoba, N., Usui, H., Fujita, H. and Yoshikawa, M. (1999). A novel antihypertensive peptide derived from ovalbumin induces nitric oxidemediated vasorelaxation in an isolated SHR mesenteric artery. FEBS Lett. 452:181-184.

Matoba, T. and Hata, H. (1972). Relationship between bitterness of peptides and their chemical structures. Agr. Biol. Chem. 36:1423-1431.

Matsufuji, H., Matsui, T., Ohshige, S., Kawasaki, T., Osajima, K. and Osajima, Y. (1995). Antihypertensive effects of angiotensin fragments in SHR. Biosci. Biotech. Biochem. 59:1398-1401.

Matsui, T., Hayashi, A., Tamaya, K., Matsumoto, K., Kawasaki, T., Murakami, K. and Kimoto, K. (2003). Depressor effect induced by dipeptides, VAL-TYR, in hypertensive transgenic mice is due, in part, to the suppression of human circulating renin-angiotensin system. Clin. Exp. Pharmacol. P. 30:262-265.

Matsui, T., Ueno, T., Tanaka, M., Oka, H., Miyamoto, T., Osajima, K. and Matsumoto, K. (2005). Antiproliferative action of an angiotensin i converting enzyme inhibitory peptide, Val-Tyr, via an L-type Ca channel inhibition in cultured vascular smooth muscle cells. Hypertens Res. 28:545-552.

Mazoyer, E., Levy-Toledano, S., Rendu, F., Hermant, L., Lu, H., Fiat, A. M., Jolles, P. and Caen, J. (1990). KRDS, a new peptide derived from human lactotransferrin, inhibits platelet aggregation and release reaction. Eur. J. Biochem. 194:43-49.

McCann, K. B., Shiell, B. J., Michalski, W. P., Lee, A., Wan, J., Roginski, H. and Coventry, M. J. (2006). Isolation and characterisation of a novel antibacterial peptide from bovine aS1-casein. Int. Dairy J. 16:316-323.

Mechkarska, M., Attoub, S., Sulaiman, S., Pantic, J., Lukic, M. L. and Conlon, J. M. (2014). Anti-cancer, immunoregulatory, and antimicrobial activities of the frog skin host-defense peptides pseudhymenochirin$1 \mathrm{~Pb}$ and pseudhymenochirin-2Pa. Regul. Pept. 194-195:69-76.

Mechkarska, M., Prajeep, M., Coquet, L., Leprince, J., Jouenne, T., Vaudry, H., King, J. D. and Conlon, J. M. (2012). The hymenochirins: A family of host-defense peptides from the Congo dwarf clawed frog Hymenochirus boettgeri (Pipidae). Peptides. 35:269-275.

Mechkarska, M., Prajeep, M., Radosavljevic, G. D., Jovanovic, I. P., Baloushi, A. A., Sonnevend, A., Lukic, M. L. and Conlon, J. M. (2013) An analog of the host-defense peptide hymenochirin-1B with potent broad-spectrum activity against multidrug-resistant bacteria and immunomodulatory properties. Peptides. 50:153-159.

Mechmeche, M., Kachouri, F., Ksontini, H. and Hamdi, M. (2017). Production of bioactive peptides from tomato seed isolate by Lactobacillus plantarum fermentation and enhancement of antioxidant activity. Food Biotechnol. 31:94-113.

Meinlschmidt, P., Ueberham, E., Lehmann, J., Schweiggert-Weisz, U. and Eisner, P. (2016). Immunoreactivity, sensory and physicochemical properties of fermented soy protein isolate. Food Chem. 205:229-238.

Messaoudi, M., Lefranc-Millot, C., Desor, D., Demagny, B. and Bourdon, L. (2005). Effects of a tryptic hydrolysate from bovine milk $\alpha$-casein on hemodynamic responses in healthy human volunteers facing successive mental and physical stress situations. Eur. J. Nutr. 44:128-132.

Micewicz, E. D., Bahattab, O. S. O., Willars, G. B., Waring, A. J., Navab, M., Whitelegge, J. P., McBride, W. H. and Ruchala, P. (2015). Small lipidated anti-obesity compounds derived from neuromedin U. Eur. J. Med. Chem. 101:616-626.

Miclo, L., Perrin, E., Driou, A., Papadopoulos, V., Boujrad, N., Vanderesse, R., Boudier, J. F., Desor, D., Linden, G. and Gaillard, J. L. (2001) 
Characterization of a-casozepine, a tryptic peptide from bovine a -casein, with benzodiazepine-like activity. FASEB J. 15:1780-1782.

Mine, Y. and Kovacs-Nolan, J. (2006). New insights in biologically active proteins and peptides derived from hen egg. World's Poultry Sci. J. 62:87-96.

Mine, Y., Ma, F. and Lauriau, S. (2004). Antimicrobial peptides released by enzymatic hydrolysis of hen egg white lysozyme. J. Agr. Food Chem. 52:1088-1094.

Mitta, G., Hubert, F., Dyrynda, E. A., Boudry, P. and Roch, P. (2000). Mytilin B and MGD2, two antimicrobial peptides of marine mussels: gene structure and expression analysis. Dev. Comp. Immun. 24:381-393.

Miyata, T., Tokunaga, F., Yoneya, T., Yoshikawa, K., Iwanaga, S., Niwa, M., Takao, T. and Shimonishi, Y. (1989). Antimicrobial peptides, isolated from horseshoe crab hemocytes, tachyplesin II, and polyphemusins I and II: chemical structures and biological activity. J. Biochem. 106:663668.

Mizushima, S., Ohshige, K., Watanabe, J., Kimura, M., Kadowaki, T., Nakamura, Y., Tochikubo, O. and Ueshima, H. (2004). Randomized controlled trial of sour milk on blood pressure in borderline hypertensive men. Am. J. Hematol. 17:701-706.

Mohanty, D. P., Mohapatra, S., Misra, S. and Sahu, P. S. (2015). Milk derived bioactive peptides and their impact on human health - A review. Saudi J. Biolog. Sci. 23:577-583.

Montagne, L., Piel, C. and Lalles, J. P. (2004). Effect of diet on mucin kinetics and composition: nutrition and health implications. Nutr. Rev. 62:105-114

Mora, L., Reig, M. and Toldrá, F. (2014). Bioactive peptides generated from meat industry by-products. Food Res. Int. 65:344-349.

Morales-Medina, R., Tamm, F., Guadix, A., Guadix, E. M. and Drusch, S. (2016). Functional and antioxidant properties of hydrolysates of sardine (S. pilchardus) and horse mackerel (T. mediterraneus) for the microencapsulation of fish oil by spray-drying. Food Chem. 194:12081216.

Morel, P. C. H., Padilla, R. M. and Ravindran, G. (2003). Effect of nonstarch polysaccharides on mucin secretion and endogenous amino acid losses in pigs. Asian-Aust J. Anim. Sci. 16:1332-1338.

Morimatsu, F., Ito, M., Budijanto, S., Watanabe, I., Furukawa, Y. and Kimura, S. (1996). Plasma cholesterol-suppressing effect of papainhydrolyzed pork meat in rats fed hypercholesterolemic diet. J. Nutr. Sci. Vitaminol. 42:145-153.

Morris, H. J., Carrillo, O. V., Almarales, A., Bermúdez, R. C., Alonso, M. E., Borges, L., Quintana, M. M., Fontaine, R., Llauradó, G. and Hernández, M. (2009). Protein hydrolysates from the alga chlorella vulgaris $87 / 1$ with potentialities in immunonutrition. Biotecnol. Apl. 26:163-165.

Motoi, H. and Kodama, T. (2003). Isolation and characterization of angiotensin I-converting enzyme inhibitory peptides from wheat gliadin hydrolysate. Mol. Nutr. Food Res. 47:354-358.

Moughan, P. J., Rutherfurd, S. M. and Balan, P. (2013). Kiwifruit, mucins, and the gut barrier. Adv. Food Nutr. Res. 68:169-185.

Muguruma, M., Ahhmed, A. M., Katayama, K., Kawahara, S., Maruyama, M. and Nakamura, T. (2009). Identification of pro-drug type ACE inhibitory peptide sourced from porcine myosin B: Evaluation of its antihypertensive effects in vivo. Food Chem. 114:516-522.

Mullally, M. M., Meisel, H. and FitzGeralc, R. J. (1997). Identification of a novel angiotensin-I-converting enzyme inhibitory peptide corresponding to a tryptic fragment of bovine B-lactoglobulin. FEBS Lett. 402:99101.

Multilangi, W. A. M., Panyam, D. and Kilara, A. (1996). Functional properties of hydrolysate from proteolysis of heat-denatured whey protein isolate. J. Food Sci. 61:270-274.

Murakami, T. A., Niwa, M. B., Tokunaga, F. C., Miyata, T. C. and Iwanaga, S. (1991). Direct virus inactivation of tachyplesin I and its isopeptides from horseshoe crab hemocytes. Chemotherapy. 37:327-334.

Mune, M. A. M. (2015). Influence of degree of hydrolysis on the functional properties of cowpea protein hydrolysates. J. Food Process. Pres. 39:2386-2392.

Mutilangi, W. A. M., Panyam, D. and Kilara, A. (1996). Functional properties of hydrolysates from proteolysis of heat-denaturateed whey protein isolate. J. Food Sci. 61:270-275.

Nagai, T., Suzuki, N. and Nagashima, T. (2006). Antioxidative activities and angiotensin I-converting enzyme inhibitory activities of enzymatic hydrolysates from commercial kamaboko type samples. Food Sci. Tech. Int. 12:335-346.

Nagaune, S., Azuma, N., Ishino, Y., Mori, H., Kaminogawa, S. and Yamauchi, K. (1989). DNA-synthesis stimulating peptide from bovine jSCasein. AgrBioL Chem. 53:3275-3278.

Nair, P., Yamamoto, T., Cowell, S., Kulkarni, V., Moye, S., Navratilova, E., Davis, P., Ma, S. W., Vanderah, T. W., Lai, J., Porreca, F. and Hruby, V. J. (2015). Discovery of tripeptide-derived multifunctional ligands possessing delta/mu opioid receptor agonist and neurokinin 1 receptor antagonist activities. Bioorg Med. Chem. Lett. 25:3716-3720.

Nakamura, T., Mizutani, J., Ohki, K., Yamada, K., Yamamota, N., Takeshi, M. and Takazawa, K. (2011). Casein hydrolysate containing Val-ProPro and Ile-Pro-Pro improves central blood pressure and arterial stiffness in hypertensive subjects: A randomized, double-blind, placebocontrolled trial. Atherosclerosis. 219:298-303.

Nakamura, Y., Yamamoto, N., Sakai, K., Okubo, A., Yamazaki, S. and Takano, T. (1995). Purification and characterization of angiotensin Iconverting enzyme inhibitors from sour milk. J. Dairy Sci. 78:777-783.

Nakano, D., Ogura, K., Miyakoshi, M., Ishii, F., Kawanishi, H., Kurumazuka, D., Kwak, C. J., Ikemura, K., Takaoka, M., Moriguchi, S., Iino, T., Kusumoto, A., Asami, S., Shibata, H., Kiso, Y. and Matsumura, Y. (2006). Antihypertensive effect of angiotensin, I-converting enzyme inhibitory peptides from a sesame protein hydrolysate in spontaneously hypertensive rats. Biosci. Biotechnol. Biochem. 70:1118-1126.

Nakashima, Y., Arihara, K., Sasaki, A., Mio, H., Ishikawa, S. and Itoh, M. (2002). Antihypertensive activities of peptides derived from porcine skeletal muscle myosin in spontaneously hypertensive rats. J. Food Sci. 67:434-437.

Narayana, J. L. and Chen, J. Y. (2015). Antimicrobial peptides: Possible anti-infective agents. Peptides. 72:88-94.

Nedjar-Arroume, N., Dubois-Delval, V., Miloudi, K., Daoud, R., Krier, F. Kouach, M., Briand, G. and Guillochon, D. (2006). Isolation and characterization of four antibacterial peptides from bovine hemoglobin. Peptides. 27:2082-2089.

Ney, K. H. (1971). Prediction of bitterness of peptides from their amino acid composition. Z Lebensm Unters For. 147:64-68.

Whitehurst, R. J. and van Oort, M. (2009). Enzymes in protein modification. In: Enzymes in Food Technology, pp. 292-319. Nielsen, P. M., Ed., Blackwell Publishing Ltd., New York.

Nii, Y., Fukuta, K., Yoshimoto, R., Sakai, K. and Ogawa, T. (2008). Determination of antihypertensive peptides from an izumi shrimp hydrolysate. Biosci. Biotechnol. Biochem. 72:861-864.

Newman, J., O'Riordan, D., Jacquier, J. C. and O'Sullivan, M. (2015). Masking of bitterness in dairy protein hydrolysates: Comparison of an electronic tongue and a trained sensory panel as means of directing the masking strategy. LWT - Food Sci. Technol. 63:751-757.

Ngo, D., Qian, Z., Ryu, B., Park, J. W. and Kim, S. (2010). In vitro antioxidant activity of a peptide isolated from Nile tilapia (Oreochromis niloticus) scale gelatin in free radical-mediated oxidative systems. J. Funct. Foods. 2:107-117.

Ngo, D. H., Vo, T. S., Ngo, D. N., Wijesekara, I. and Kim, S. K. (2012). Biological activities and potential health benefits of bioactive peptides derived from marine organisms. Int. J. Biol. Macromol. 51:378-383.

Nimalaratne, C. and Wu, J. (2015). Hen egg as an antioxidant food commodity: A review. Nutrients. 7:8274-8293.

Nishi, T., Hara, H., Asano, K. and Tomita, F. (2003b). The soybean B-conglycinin B51-63 fragment suppresses appetite by stimulating cholecystokinin release in rats. J. Nutr. 133:2537-2542.

Nishi, T., Hara, H. and Tomita, F. (2003a). Soybean-conglycinin peptone suppresses food intake and gastric emptying by increasing plasma cholecystokinin levels in rats. J. Nutr. 133:352-357.

Nishiwaki, T., Yoshimizu, S., Furuta, M. and Hayashi, K. (2002). Debittering of enzymatic hydrolysates using an aminopeptidase from the edible basidiomycete Grifola frondosa. J. Biosci. Bioeng. 93:60-63.

Nongonierma, A. B. and FitzGerald, R. J. (2016a). Strategies for the discovery, identification and validation of milk protein-derived bioactive peptides. Trends Food Sci. Technol. 50:26-43.

Nongonierma, A. B. and Fitzgerald, R. J. (2016b). Learnings from quantitative structure-activity relationship (QSAR) studies with respect to food protein-derived bioactive peptides: A review. RSC Adv. 6(79):7540075413. 
Nongonierma, A. B., Mooney, C., Shields, D. C. and Fitzgerald, R. J. (2014). In silico approaches to predict the potential of milk protein-derived peptides as dipeptidyl peptidase IV (DPP-IV) inhibitors. Peptides 57:43-51.

Norris, R. and Fitzgerad, R. J. (2013). Antihypertensive peptides from food proteins. In: Bioactive Food Peptides in Health and Disease, pp. 45-72. Hernández-Ledesma, B. and Hsieh, C. C., Eds., InTech, Osaka.

Oda, H., Wakabayashi, H., Yamauchi, K., Sato, T., Xiao, J. Z., Abe, F. and Iwatsuki, K. (2013). Isolation of a bifidogenic peptide from the pepsin hydrolysate of bovine lactoferrin. Appl. Environ. Microbiol. 79:18431849.

Ohba, R., Deguchi, T., Kishikawa, M., Arsyad, F., Morimura, S. and Kida, K. (2003). Physiological functions of enzymatic hydrolysates of collagen or keratin contained in livestock and fish waste. Food Sci. Technol. Res. 9:91-93.

Ohta, M., Ito, H., Masuda, K., Tanaka, S., Arakawa, Y., Wacharotayankun, R. and Kato, N. (1992). Mechanisms of antibacterial action of tachyplesins and polyphemusins, a group of antimicrobial peptides isolated from horseshoe crab hemocytes. Antimicrob. Agents Ch. 36:1460-1465.

O’Loughlin, I. B., Murray, B. A., FitzGerald, R. J., Brodkorb, A. and Kelly, P. M. (2014). Pilot-scale production of hydrolysates with altered biofunctionalities based on thermallydenatured whey protein isolate. Int. Dairy J. 34:146-152.

Opheim, M., Slizyte, R., Sterten, H., Provan, F., Larssen, E. and Kjos, N. P. (2015). Hydrolysis of Atlantic salmon (Salmo salar) rest raw materials - Effect of raw material and processing on composition, nutritional value, and potential bioactive peptides in the hydrolysates. Process Biochem. 50:1247-1257.

Oren, Z. and Shai, Y. (1996). A class of highly potent antibacterial peptides derived from pardaxin, a pore-forming peptide isolated from Moses sole fish Pardachirus marmoratus. Eur. J. Biochem. 237:303-310.

Osaki, T., Omotezako, M., Nagayama, R., Hirata, M., Iwanaga, S., Kasahara, J., Hattori, J., Ito, I., Sugiyama, H. and Kawabata, S. I. (1999). Horseshoe crab hemocyte-derived antimicrobial polypeptides, tachystatins, with sequence similarity to spider neurotoxins. J. Biolog. Chem. 274:26172-26178.

Oseguera-Toledo, M. E., De Mejia, E. G. and Amaya-Llano, S. L. (2015). Hard-to-cook bean (Phaseolus vulgaris L.) proteins hydrolyzed by alcalase and bromelain produced bioactive peptide fractions that inhibit targets of type-2 diabetes and oxidative stress. Food Res. Int. 76:839-851.

Oseguera-Toledo, M. E., De Mejia, E. G., Dia, V. P. and Amaya-Llano, S. L. (2011). Common bean (Phaseolus vulgaris L.) hydrolysates inhibit inflammation in LPS-induced macrophages through suppression of NF-jB pathways. Food Chem. 127:1175-1185.

Otte, J., Ju, Z. Y., Færgemand, M., Lomholt, S. B. and Qvist, K. B. (1996). Protease-induced aggregation and gelation of whey proteins. J. Food Sci. 61:911-916.

Otte, A., Ettlin, T. M., Nitzsche, E. U., Wachter, K., Hoegerle, S., Simon, G. H., Fierz, L. and Moser, E. (1997). Mueller-Brand J. PET and SPECT in whiplash syndrome: a new approach to a forgotten brain? J. Neurol. Neurosurg Psychiatry. 63:368-372.

Padhi, A. and Verghese, B. (2008). Molecular diversity and evolution of myticin-C antimicrobial peptide variants in the Mediterranean mussel, Mytilus galloprovincialis. Peptides. 29:1094-1101.

Park, K. J. and Hyun, C. K. (2002). Antigenotoxic effects of the peptides derived from bovine blood plasma proteins. Enzyme Microb. Tech. 30:633-638.

Park, K. J., Jin, H. H. and Hyun, C. K. (2002). Antigenotoxicity of peptides produced from silk fibroin. Process Biochem. 38:411-418.

Park, C. B., Lee, J. H., Park, I. Y., Kim, M. S. and Kim, S. C. (1997). A novel antimicrobial peptide from the loach, Misgurnus anguillicaudatus. FEBS Lett. 411:173-178.

Parker, F., Migliore-Samour, D., Floch, F., Zerial, A., Werner, G. H., Jolles, J., Casaretto, M., Zahn, H. and Jolles, P. (1984). Immunostimulating hexapeptide from human casein: amino acid sequence, synthesis and biological properties. Eur. J. Biochem. 45:677-682.

Pan, D., Luo, Y. and Tanokura, M. (2005). Antihypertensive peptides from skimmed milk hydrolysate digested by cell-free extract of lactobacillus helveticus JCM1004. Food Chem. 91:123-129.
Pedersen, N. L. R., Nagain-Domaine, C., Mahe, S., Chariot, J., Roze, C. and Tome, D. (2000). Caseinomacropeptide specifically stimulates exocrine pancreatic secretion in the anesthetized rat. Peptides. 21:1527-1535.

Pellegrini, A., Thomas, U., Bramaz, N., Hunziker, P. and Fellenberg, R. (1999). Isolation and identiథcation of three bactericidal domains in the bovine K-lactalbumin molecule. Biochim. Biophys. Acta. 1426:439-448.

Petit, V. W., Rolland, J. L., Blond, A., Cazevieille, C., Djediat, C., Peduzzi, J., Goulard, C., Bachère, E., Dupont, J., Destoumieux-Garzón, D. and Rebuffat, S. (2016). A hemocyanin-derived antimicrobial peptide from the penaeid shrimp adopts an alpha-helical structure that specifically permeabilizes fungal membranes. Biochim. Biophys. Acta. 1860:557568.

Pescuma, M., Hébert, E. M., Haertlé, T., Chobert, J. M., Mozzi, F. and Font de Valdez, G. (2015). Lactobacillus delbrueckii subsp. bulgaricus CRL 454 cleaves allergenic peptides of b-lactoglob. Food Chem. 170:407414.

Pettit, R. K., Pettit, G. R. and Hazen, K. C. (1998). Specific activities of dolastatin 10 and peptide derivatives against cryptococcus neoformans. Antimicrob. Agents Ch. 42:2961-2965.

Pihlanto-Leppala, A., Koskinen, P., Piilola, K., Tupasela, T. and Korhonen, H. (2000). Angiotensin I-converting enzyme inhibitory properties of whey protein digests: concentration and characterization of active peptides. J. Dairy Res. 67:53-64.

Piot, J. M., Zhao, Q., Guillochon, D., Ricard, G. and Thomas, D. (1992). Isolation and characterization of two opioid peptides from a bovine hemoglobin peptic hydrolysate. Biochem. Bioph. Res. Co. 189:101-110.

Pisuttharachai, D., Fagutao, F. F., Yasuike, M., Aono, H., Yano, Y., Murakami, K., Kondo, H., Aoki, T. and Hirono, I. (2009). Characterization of crustin antimicrobial proteins from Japanese spiny lobster Panulirus japonicas. Dev. Comp. Immunol. 33:1049-1054.

Plaza, A., Bifulco, G., Keffer, J. L., Lloyd, J. R., Baker, H. L. and Bewley, C. A. (2009). Celebesides A-C and theopapuamides B-D, depsipeptides from an Indonesian sponge that inhibit HIV-1 entry. J. Org. Chem. 74:504-512.

Plaza, A., Gustchina, E., Baker, H. L., Kelly, M. and Bewley, C. A. (2007). Mirabamides A-D, depsipeptides from the sponge Siliquariaspongia mirabilis that inhibit HIV-1 fusion. J. Nat. Prod. 70:1753-1760.

Power, O., Jakeman, P. and Fitzerald, R. J. (2013). Antioxidative peptides: enzymatic production, in vitro and in vivo antioxidant activity and potential applications of milk-derived antioxidative peptides. Amino Acids. 44:797-820.

Prasanna, P. H. P., Grandison, A. S. and Charalampopoulos, D. (2012). Effect of dairy-based protein sources and temperature on growth, acidification and exopolysaccharide production of Bifidobacterium strains in skim milk. Food Res. Int. 47:6-12.

Prieto, C. A., Guadix, E. M. and Guadix, A. (2010a). Optimal operation of a protein hydrolysis reactor with enzyme recycles. J. Food Eng. 97:24-30.

Prieto, C. A., Guadix, E. M. and Guadix, A. (2010b). Recent patents on whey protein hydrolysates manufactured by proteolysis coupled to membrane ultrafiltration. Chem. Eng. 3:115-128.

Quaglia, G. B. and Orban, E. (1987). Influence of the degree of hydrolysis on the solubility of the protein hydrolysates from Sardine (Sardine pilchardus). J. Sci. Food Agr. 38:271-276.

Quiros, A., Del Mar Contreras, M., Ramos, M., Amigo, L. and Recio, I. (2009). Stability to gastrointestinal enzymes and structure-activity relationship of b-casein-peptides with antihypertensive properties. Peptides. 30:1848-1853.

Quiros, A., Ramos, M., Muguerza, B., Delgado, M. A., Miguel, M., Aleixandre, A. and Recio, I. (2007). Identification of novel antihypertensive peptides in milk fermented with Enterococcus faecalis. Int. Dairy J. 17:33-41.

Raha, S., Dosquet, C., Abgrall, J. F., Jolles, P., Fiat, A. M. and Caen, J. P. (1988). KRDS-A tetrapeptide derived from lactotransferrininhibits binding of monoclonal antibody against glycoprotein libilla on ADP stimulated platelets and megakaryocytes. Blood. 72 (1):172-178.

Rai, A. K., Kumari, R., Sanjukta, S. and Sahoo, D. (2016). Production of bioactive protein hydrolysate using the yeasts isolated from soft churpi. Bioresource Technol. 219:239-245. 
Raghavan, S. and Kristinsson, H. G. (2008). Antioxidative efficacy of alkalitreated Tilapia protein hydrolysates: A comparative study of five enzymes. J. Agr. Food Chem. 56:1434-1441.

Rajapakse, N., Jung, W. K., Mendis, E., Moon, S. H. and Kim, S. K. (2005). A novel anticoagulant purified from fish protein hydrolysate inhibits factor XIIa and platelet aggregation. Life Sci. 76:2607-2619.

Raju, K. V. S. N., Kumar, D. A., Arutselvan, N., Thejomoorthy, P. and Puvanakrishnan, R. (2005). Antinociceptive and antipyretic effects of a derivatized tetrapeptide from lactoferrin in rats. Peptides. 26:615-619.

Raksakulthai, R and Haard, N. F. (2003). Exopeptidases and their application to reduce bitterness in food: a review. Crit. Rev. Food Sci. Nutr. 43:401-445.

Ranamukhaarachchi, S., Meissner, L. and Moresoli, C. (2013). Production of antioxidant soy protein hydrolysates by sequential ultrafiltration and nanofiltration. J. Membrane Sci. 429:81-87.

Ren, J., Zhao, M., Shi, J., Wang, J., Jiang, Y., Cui, C., Kakuda, Y. and Xue, S. J. (2008). Purification and identification of antioxidant peptides from grass carp muscle hydrolysates by consecutive chromatography and electrospray ionization-mass spectrometry. Food Chem. 108:727-736.

Rizzello, C. G., Tagliazucchi, D., Babini, E., Sefora Rutella, G., Taneyo Saa, D. L. and Gianotti, A. (2016). Bioactive peptides from vegetable food matrices: Research trends and novel biotechnologies for synthesis and recovery. J. Funct. Foods. 27:549-569.

Ruiz-Giménez, P., Salom, J. B., Marcos, J. F., Vallés, S., Martínez-Maqueda, D., Recio, I., Torregrosa, G., Alborch, E. and Manzanares, P. (2012). Antihypertensive effect of a bovine lactoferrin pepsin hydrolysate: Identification of novel active peptides. Food Chem. 131:266-273.

Rutherfurd, S. M. (2010). Methodology for determining degree of hydrolysis of proteins in hydrolysates: A review. J. AOAC Int. 93:1515-1522.

Sagardia, I., Iloro, I., Elortza, F. and Bald, C. (2013). Quantitative structureeactivity relationship based screening of bioactive peptides identified in ripened cheese. Int. Dairy J. 33:184-190.

Saiga, A., Tanabe, S. and Nishimura, T. (2003). Antioxidant activity of peptides obtained from porcine myofibrillar proteins by protease treatment. J. Agr. Food Chem. 51:3661-3667.

Salampessy, J., Reddy, N., Kailasapathy, K. and Phillips, M. (2015). Functional and potential therapeutic ACE-inhibitory peptides derived from bromelain hydrolysis of trevally proteins. J. Funct. Foods. 14:716-725.

Samaranayaka, A. G. P. and Li-chan, E. C. Y. (2008). Autolysis-assisted production of fish protein hydrolysates with antioxidant properties from Pacific hake (Merluccius productus). Food Chem. 107:768-776.

Samaranayaka, A. G. P. and Li-Chan, E. C. Y. (2011). Food-derived peptidic antioxidants: A review of their production, assessment, and potential applications. J. Funct. Foods. 3:229-254.

Sampath Kumar, N. S., Nazeer, R. A. and Jaiganesh, R. (2011). Purification and biochemical characterization of antioxidant peptide from horse mackerel (Magalaspis cordyla) viscera protein. Peptides. 32:1496-1501.

Sánchez-Rivera, L., Martínez-Maqueda, D., Cruz-Huerta, E., Miralles, B. and Recio, I. (2014). Peptidomics for discovery, bioavailability and monitoring of dairy bioactive peptides. Food Res. Int. 63:170-181.

Savijoki, K., Ingmer, H. and Varmanen, P. (2006). Proteolytic systems of lactic acid bacteria. Appl. Microbiol. Biot. 71:394-406.

Sanjukta, S. and Rai, A. K. (2016). Production of bioactive peptides during soybean fermentation and their potential health benefits. Trends Food Sci. Tech. 50:1-10.

Sarmadi, B. H. and Ismail, A. (2010). Antioxidative peptides from food proteins: A review. Peptides. 31:1949-1956.

Schaich, K. M. (2016). Analysis of lipid and protein oxidation in fats, oils, and foods. In: Oxidative Stability and Shelf Life of Foods Containing Oils and Fats, pp. 1-131. Hu, M. and Jacobsen, C., Eds., AOCS Press, Cambridge.

Sentandreu, M. A. and Toldra, F. (2007). Evaluation of ACE inhibitory activity of dipeptides generated by the action of porcine muscle dipeptidyl peptidases. Food Chem. 102:511-515.

Shahidi, F. (2015). Antioxidants: principles and applications. In: Handbook of Antioxidants for Food Preservation, pp. 1-14. Shahidi, F., Ed., Woodhead Publishing, Cambridg.

Shahidi, F. and Zhong, Y. (2015). Measurement of antioxidant activity. J. FunctFoods. 18:757-781.

Sheih, I. C., Wu, T. K. and Fang, T. J. (2009a). Antioxidant properties of a new antioxidative peptide from algae protein waste hydrolysate in different oxidation systems. Bioresource Technol. 100:3419-3425.
Sheih, I., Fang, T. J. and Wu, T. (2009b). Isolation and characterisation of a novel angiotensin I-converting enzyme (ACE) inhibitory peptide from the algae protein waste. Food Chem. 115:279-284.

Shekh, R. M. and Roy, U. (2012). Biochemical characterization of an anti-Candida factor produced by Enterococcus faecalis. BMC Microb. 12:1-15.

Sheu, F., Chien, P. J., Chien, A. L., Chen, Y. F. and Chin, K. L. (2004). Isolation and characterization of an immunomodulatory protein (APP) from the Jew's ear mushroom Auricularia polytricha. Food Chem. 87:593-600.

Shimizu, M., Sawashita, N., Morimatsu, F., Ichikawa, J., Taguchi, Y., Ijiri, Y. and Yamamoto, J. (2009). Antithrombotic papain-hydrolyzed peptides isolated from pork meat. Thromb. Res. 123:753-757.

Shin, Z. I., Yu, R., Park, S. A., Chung, D. K., Ahn, C. W., Nam, H. S., Kim, K. S. and Lee, H. J. (2001). His-His-Leu, an angiotensin I converting enzyme inhibitory peptide derived from Korean soybean paste, exerts antihypertensive activity in aivo. J. Agr. Food Chem. 49:3004-3009.

Sila, A. and Bougatef, A. (2016). Antioxidant peptides from marine byproducts: Isolation, identification and application in food systems. A review. J. Funct. Foods. 21:10-26.

Singh, B. P., Vij, S. and Hati, S. (2014). Functional significance of bioactive peptides derived from soybean. Peptides. 54:171-179.

Sipola, M., Finckenberg, P., Vapaatalo, H., Pihlanto-Leppala, A., Korhonen, H., Korpela, R. and Nurminen, M. L. (2002). Lactorphin and hlactorphin improve arterial function in spontaneously hypertensive rats. Life Sci. 71:1245-1253.

Šližyte, R., Daukšas, E., Falch, E., Storrø, I. and Rustad, T. (2005). Characteristics of protein fractions generated from hydrolysed cod (Gadus morhua) by-products. Process Biochem. 40:2021-2033.

Sluis, M. V. D., De Koning, B. A. E., De Bruijn, A. C. J. M., Velcich, A., Meijerink, J. P. P., Goudoever, J. B. V., Buller, H. A., Dekker, J., Seuningen, I. V., Renes, I. B. and Einerhand, A. W. C. (2006). Muc2-Deficient mice spontaneously develop colitis, indicating that muc2 is critical for colonic protection. Gastroenterology. 131:117-129.

Srinivasan, D., Mechkarska, M., Abdel-Wahab, Y. H. A., Flatt, P. R. and Conlon, J. M. (2013). Caerulein precursor fragment (CPF) peptides from the skin secretions of Xenopus laevis and Silurana epitropicalis are potent insulin-releasing agents. Biochimie. 95:429-435.

Souissi, N., Bougatef, A., Triki-Ellouz, Y. and Nasri, M. (2007). Biochemical and functional properties of Sardinella (Sardinella aurita) by-products hydrolysates. Food Technol. Bio. 45:187-194.

Souza, B. M., Mendes, M. A., Santos, L. D., Marques, M. R., Cesar, L. M. M., Almeida, R. N. A., Pagnocca, F. C., Konno, K. and Palma, M. S. (2005). Structural and functional characterization of two novel peptide toxins isolated from the venom of the social wasp Polybia paulista. Peptides. 26:2157-2164.

Spellman, D., O'Cuinn, G. and FitzGerald, R. J. (2009). Bitterness in Bacillus proteinase hydrolysates of whey proteins. Food Chem. 114:440-446.

Stanley, D. W. (1981). Non-bitter protein hydrolysates. Can. Inst. Food Sei. Technol. J. 14:49-52.

Stevenson, D. E., Ofman, D. J., Morgan, K. R. and Stanley, R. A. (1998). Protease-catalyzed condensation of peptides as a potential means to reduce the bitter taste of hydrophobic peptides found in protein hydrolysates. Enzyme Microb. Tech. 22:100-110.

Su, G., Zhao, T., Zhao, Y., Sun-Waterhouse, D., Qiu, C., Huang, P. and Zhao, M. (2016). Effect of anchovy (Coilia mystus) protein hydrolysate and its Maillard reaction product on combating memory-impairment in mice. Food Res. Int. 82:112-120.

Sun, H. X., Chen, L. Q., Zhang, J. and Chen, F. Y. (2014). Anti-tumor and immunomodulatory activity of peptide fraction from the larvae of Musca domestica. J. Ethnopharmacol. 153:831-839.

Synowiecki, J., Jagielka, R. and Shahidi, F. (1996). Preparation of hydrolysates from bovine red blood cells and their debittering following plastein reaction. Food Chem. 57:435-439.

Taheri, A., Farvin, K. H. S., Jacobsen, C. and Baron, C. P. (2014). Antioxidant activities and functional properties of protein and peptide fractions from salted herring brine. Food Chem. 142:318-326.

Takahashi, M., Fukunaga, H., Kaneto, H., Fukudome, S. and Yoshikawa, M. (2000). Behavioral and pharmacological studies on gluten exorphin A5, a newly isolated bioactive food protein fragment, in mice. Jpn. J. Pharmacol. 84:259-265. 
Takahashi, M., Moriguchi, S., Yoshikawa, M. and Sasaki, R. (1994). Isolation and characterization of oryzatensin: A novel bioactive peptide with ileum-contracting and immunomodulating activities derived from rice albumin. Biochem. Mol. Biol. Int. 33:1151-1158.

Takahashi, S., Nakashima, Y. and Toda, K. (2009). Carnosine facilitates nitric oxide production in endothelial F-2 cells. Biol. Pharm. Bull. 32:1836-1839.

Takenaka, Y., Utsumi, S. and Yoshikawa, M. (2000). Introduction of enterostatin (VPDPR) and a related sequence into soybean proglycinin AlaB1b subunit by site-directed mutagenesis. Biosci. Biotechnol. Biochem. 64:2731-2733.

Takeuchi, T., Hayashida, K., Inagaki, H., Kuwahara, M., Tsubone, H. and Harada, E. (2003). Opioid mediated suppressive effect of milk-derived lactoferrin on distress induced by maternal separation in rat pups. Brain Res. 979:216-224.

Tamm, F., Gies, K., Diekmann, S., Serfert, Y., Strunskus, T., Brodkorb, A. and Drusch, S. (2015). Whey protein hydrolysates reduce autoxidation in microencapsulated long chain polyunsaturated fatty acids. Eur. J. Lipid Sci. Technol. 117:1960-1970.

Tan, S. H., Mailer, R. J., Blanchard, C. L. and Agboola, S. O. (2011). Canola proteins for human consumption: extraction, profile, and functional properties. J. Food Sci. 76(1):R16-R28.

Tang, W., Zhang, H., Wang, L., Qian, H. and Qi, X. (2015). Targeted separation of antibacterial peptide from protein hydrolysate of anchovy cooking wastewater by equilibrium dialysis. Food Chem. 168:115-123.

Thang, C. L. and Zhao, X. (2015). Effects of orally administered immunodominant T-cell epitope peptides on cow's milk protein allergy in a mouse model. Food Res. Int. 71:126-131.

Tokunaga, K., Yoshida, C., Suzuki, K., Maruyama, H., Futamura, Y., Araki, Y. and Mishima, S. (2004). Antihypertensive effect of peptides from royal jelly in spontaneously hypertensive rats. Biol. Pharm. Bull. 27:189-192.

Tsai, J. S., Chen, J. L. and Pan, B. S. (2008). ACE-inhibitory peptides identified from the muscle protein hydrolysate of hard clam (Meretrix lusoria). Process Biochem. 43:743-747.

Tsuchiya, T., Takeuchi, T., Hayashida, K. I., Shimizu, H., Ando, K. and Harada, E. (2006). Milk-derived lactoferrin may block tolerance to morphine analgesia. Brain Res. 1068:102-108.

Turgeon, S. L., Gauthier, S. F. and Paquin, P. (1991). Interfacial and emulsifying properties of whey peptide fractions obtained with a two-step ultrafiltration process. J. Agr. Food Chem. 39:673-676.

Turner, T., Jackson, W. H., Pettit, G. R., Wells, A. and Kraft, A. S. (1998). Treatment of human prostate cancer cells with dolastatin 10, a peptide isolated from a marine shell-less mollusc. Prostate. 34:175-181.

Udenigwe, C. C. (2014). Bioinformatics approaches, prospects and challenges of food bioactive peptide research. Trends Food Sci. Technol. 36 (2):137-143.

Udenigwe, C. C. and Aluko, R. E. (2012). Multifunctional cationic peptide fractions from flaxseed protein hydrolysates. Plant Foods Hum. Nutr. 67:1-9.

Udenigwe, C. C., Gong, M. and Wu, S. (2013). In silico analysis of the large and small subunits of cereal RuBisCO as precursors of cryptic bioactive peptides. Process Biochem. 48(11):1794-1799.

Udenigwe, C. C. and Rajendran, S. R. C. K. (2016). Old products, new applications? Considering the multiple bioactivities of plastein in peptide-based functional food design. Cur. Opin. Food Sci. 8:8-13.

Uyttendaele, M. and Debevere, J. (1994). Evaluation of the antimicrobial activity of protamine. Food Microbiol. 11:417-427.

Vaishampayan, U., Glode, M., Du, W., Kraft, A., Hudes, G., Wright, J. and Hussain, M. (2000). Phase II study of dolastatin-10 in patients with hormone-refractory metastatic prostate adenocarcinoma. Clin. Cancer Res. 6:4205-4208.

Vallabha, V. S. and Tiku, P. K. (2014). Antihypertensive peptides derived from soy protein by fermentation. Int. J. Pept. Res. Ther. 20:161-168.

Valjakka, M., Vapaavuori, E., Haggman, H. and Kangasjarvi, J. (1997). The electronic plant gene register. Plant Physiol. 114:1567-1569.

Vaštag, T., Popović, L., Popović, S., Krimer, V. and Peričin, D. (2011). Production of enzymatic hydrolysates with antioxidant and angiotensin-I converting enzyme inhibitory activity from pumpkin oil cake protein isolate. Food Chem. 124:1316-1321.
Vavrusova, M., Pindstrup, H., Johansen, L. B., Andersen, M. L., Andersen, H. J. and Skibsted, L. H. (2015). Characterisation of a whey protein hydrolysate as antioxidant. Int. Dairy J. 47:86-93.

Venuste, M., Zhang, X., Shoemaker, C. F., Karangwa, E., Abbas, S. and Kamdem, P. E. (2013). Influence of enzymatic hydrolysis and enzyme type on the nutritional and antioxidant properties of pumpkin meal hydrolysates. Food Funct. 4:811-820.

Vercruysse, L., Camp, J. V. and Smagghe, G. (2005). ACE inhibitory peptides derived from enzymatic hydrolysates of animal muscle protein: a review. J. Agr. Food Chem. 53:8106-8115.

Vercruysse, L., Morel, N., Camp, J. V., Szust, J. and Smagghe, G. (2008). Antihypertensive mechanism of the dipeptide Val-Tyr in rat aorta. Peptides. 29:261-267.

Vlieghe, P., Lisowski, V., Martinez, J. and Khrestchatisky, M. (2010). Synthetic therapeutic peptides: science and market. Drug Discov. Today. 15:40-56.

Vo, T. S. and Kim, S. K. (2013). Down-regulation of histamine-induced endothelial cell activation as potential anti-atherosclerotic activity of peptides from Spirulina maxima. Eur. J. Pharm. Sci. 50:198-207.

Wada, Y. and Lönnerdal, B. (2014). Bioactive peptides derived from human milk proteins - mechanisms of action. J. Nutr. Biochem. 25:503-514.

Wang, C. H. and Damodaran, S. (1990). Thermal gelation of globular proteins: weight-average molecular weight dependence of gel strength. $J$. Agr. Food Chem. 38:1157-1164.

Wang, H. and Ng, T. B. (2004). Eryngin, a novel antifungal peptide from fruiting bodies of the edible mushroom Pleurotus eryngii. Peptides. 25:1-5.

Wang, H. X. and Ng, T. B. (2007). Isolation and characterization of an antifungal peptide with antiproliferative activity from seeds of Phaseolus vulgaris cv. 'Spotted Bean'. Appl. Microbiol. Biotechnol. 74:125-130.

Wang, J., Hu, J., Cui, J., Bai, X., Du, Y., Miyaguchi, Y. and Lin, B. (2008a). Purification and identification of a ACE inhibitory peptide from oyster proteins hydrolysate and the antihypertensive effect of hydrolysate in spontaneously hypertensive rats. Food Chem. 111:302-308.

Wang, J. Z., Zhang, H., Zhang, M, Yao, W. T., Mao, X. Y. and Ren, F. Z. (2008b). Antioxidant activity of hydrolysates and peptide fractions of porcine plasma albumin and globulin. J. Food Biochem. 32:693-707.

Wang, K., Jia, F., Dang, W., Zhao, Y., Zhu, R., Sun, M., Qiu, S., An, X., Ma, Z., Zhu, Y., Yan, J., Kong, Z., Yan, W. and Wang, R. (2016). Antifungal effect and action mechanism of antimicrobial peptide polybia-CP. $J$. Pept. Sci. 22:28-35.

Wergedahl, H., Liaset, B., Gudbrandsen, O. A., Lied, E., Espe, M., Muna, Z., Mork, S. and Berge, R. K. (2004). Fish protein hydrolysate reduces plasma total cholesterol, increases the proportion of HDL cholesterol, and lowers Acyl-CoA: cholesterol acyltransferase activity in liver of zucker rats. J. Nutr. 134:1320-1327.

Wesson, K. J. and Hamann, M. T. (1996). Keenamide A, a bioactive cyclic peptide from the marine mollusk Pleurobranchus forskalii. J. Nat. Prod. 59:629-631.

Wong, J. H., Ip, D. C. W., Ng, T. B., Chan, Y. S., Fang, F. and Pan, W. L. (2012). A defensin-like peptide from Phaseolus vulgaris cv. 'King Pole Bean'. Food Chem. 135:408-414.

Wouters, A. G., Rombouts, I., Fierens, E., Brijs, K. and Delcour, J. A. (2016). Relevance of the functional properties of enzymatic plant protein hydrolysates in food systems. Compr. Rev. Food Sci. Food Saf, In press.

Woyke, T., Pettit, G. R., Winkelmann, G. and Pettit, R. K. (2001). In vitro activities and postantifungal effects of the potent dolastatin 10 derivative auristatin PHE. Antimicrob. Agents Ch. 45:3580-3584.

Wu, H., Ong, Z. Y., Liu, S., Li, Y., Wiradharma, N. and Yang, Y. Y. (2015a) Synthetic b-sheet forming peptide amphiphiles for treatment of fungal keratitis. Biomaterials. 43:44-49.

Wu, H. T., Jin, W. G., Sun, S. G., Li, X. S., Duan, X. H., Li, Y., Yang, Y. T., Han, J. R. and Zhu, B. W. (2016a). Identification of antioxidant peptides from protein hydrolysates of scallop (Patinopecten yessoensis) female gonads. Eur. Food Res. Technol. 242:713-722.

Wu, Q., Jia, J., Yan, H., Du, J. and Gui, Z. (2015b). A novel angiotensin-I converting enzyme (ACE) inhibitory peptide from gastrointestinal 
protease hydrolysate of silkworm pupa (Bombyx mori) protein: Biochemical characterization and molecular docking study. Peptides. 68:17-24.

Wu, Q., Du, J., Jia, J. and Kuang, C. (2016b). Production of ACE inhibitory peptides from sweet sorghum grain protein using alcalase: Hydrolysis kinetic, purification and molecular docking study. Food Chem. 199:140-149.

Wu, X., Sun, J., Zhang, G., Wang, H. and Ng, T. B. (2011). An antifungal defensin from Phaseolus vulgaris cv. 'Cloud Bean'. Phytomedicine. 18:104-109.

Xhindoli, D., Pacor, S., Benincasa, M., Scocchi, M., Gennaro, R. and Tossi, A. (2016). The human cathelicidin LL-37 - A pore-forming antibacterial peptide and host-cell modulator. Biochim. Biophys. Acta. 1858:546-566.

Xie, H., Huff, G. R., Huff, W. E., Balog, J. M. and Rath, N. C. (2002). Effects of ovotransferrin on chicken macrophages and heterophil-granulocytes. Dev. Comp. Immunol. 26:805-815.

$\mathrm{Xu}, \mathrm{L}$., Du, B. and Xu, B. (2015). A systematic, comparative study on the beneficial health components and antioxidant activities of commercially fermented soy products marketed in China. Food Chem. 174:202-213.

$\mathrm{Xu}, \mathrm{X}$., Cao, R., He, L. and Yang, N. (2009). Antioxidant activity of hydrolysates derived from porcine plasma. J. Sci. Food Agric. 89:1897-1903.

Yamada, A., Sakurai, T., Ochi, D., Mitsuyama, E., Yamauchi, K. and Abe, F. (2013). Novel angiotensin I-converting enzyme inhibitory peptide derived from bovine casein. Food Chem. 141:3781-3789.

Yamada, A., Sakurai, T., Ochi, D., Mitsuyama, E., Yamauchi, K. and Abe, F. (2015). Antihypertensive effect of the bovine casein-derived peptide Met-Lys-Pro. Food Chem. 172:441-446.

Yamamoto, N. (2010). Functional food products with antihypertensive effects. In: Bioactive Proteins and Peptides as Functional Foods and Nutraceuticals, pp. 169-177. Mine, Y., Li-Chan, E. C. Y. and Jiang, B., Eds., Wiley-Blackwell, Oxford, UK.

Yin, H., Pu, J., Wan, Y., Xiang, B., Bechtel, P. J. and Sathivel, S. (2010). Rheological and functional properties of carfish skin protein hydrolysates. J. Food Sci. 75:E11-E17.

Yoshikawa, M., Fujita, H., Matoba, N., Takenaka, Y., Yamamoto, T., Yamauchi, R., Tsuruki, H. and Takahata, K. (2000). Bioactive peptides derived from food proteins preventing lifestyle-related diseases. BioFactors. 12:143-146.

Yoshikawa, M., Tani, F., Yoshimura, T. and Chiba, H. (1986). Opioid peptides from milk proteins. Agr. Biol. Chem. 50:2419-2421.

Yu, Y., Hu, J., Miyaguchi, Y., Bai, X., Du, Y. and Lin, B. (2006). Isolation and characterization of angiotensin I-converting enzyme inhibitory peptides derived from porcine hemoglobin. Peptides. 27:2950-2956.

Yu, Y. J., Amorim, M., Marques, C., Calhau, C. and Pintado, M. (2016). Effects of whey peptide extract on the growth of probiotics and gut microbiota. J. Func. Foods. 21:507-516.

Yu, Z., Yin, Y., Zhao, W., Chen, F. and Liu, J. (2014). Antihypertensive effect of angiotensin-converting enzyme inhibitory peptide RVPSL on spontaneously hypertensive rats by regulating gene expression of the renin-angiotensin system. J. Agr. Food Chem. 62:912-917.

Yu, Z., Yin, Y., Zhao, W., Liu, J. and Chen, F. (2012). Anti-diabetic activity peptides from albumin against a-glucosidase and a-amylase. Food Chem. 135:2078-2085.
Zambrowicz, A., Eckert, E., Pokora, M., Bobak, M., Dąbrowska, A., Szołtysik, M., Trziszka, T. and Chrzanowska, J. (2015). Antioxidant and antidiabetic activities of peptides isolated from a hydrolysate of an egg-yolk protein by-product prepared with a proteinase from Asian pumpkin (Cucurbita ficifolia). RSC Adv. 5:10460-10467.

Zarei, M., Forghani, B., Ebrahimpour, A., Abdul-Hamid, A., Anwar, F. and Saari, N. (2015). In vitro and in vivo antihypertensive activity of palm kernel cake protein hydrolysates: Sequencing and characterization of potent bioactive peptides. Ind. Crop. Prod. 76:112-120.

Zhang, L., Ravipati, A. S., Koyyalamudi, S. R., Jeong, S. C., Reddy, N., Bartlett, J., Smith, P. T., De la Cruz, M., Monteiro, M. C., Melguizo, A., Jimenez, E. and Vicente, F. (2013). Anti-fungal and anti-bacterial activities of ethanol extracts of selected traditional Chinese medicinal herbs. Asian Pac. J. Trop. Med. 6(9):673-681.

Zhang, Q., Ren, J., Zhao, H., Zhao, M., Xu, J. and Zhao, Q. (2011). Influence of casein hydrolysates on the growth and lactic acid production of Lactobacillus delbrueckii subsp. bulgaricus and Streptococcus thermophilus. Int. J. Food Sci. Technol. 46:1014-1020.

Zhao, D., Lu, F., Ding, Y. and Zhou, X. (2016a). Physicochemical characteristics, protein hydrolysis and textual properties of surimi during fermentation with Actinomucor elegans. Int. J. Food Prop. 20:538-548.

Zhao, H., Zhao, F., Wang, L., Fengling, B., Dziugan, P. and Walczak, P. (2014). Characterization of a bioactive peptide with cytomodulatory effect released from casein. Eur. Food Res. Technol. 238:315-322.

Zhao, Y. J., Hu, Y. and Luo, H. Y. (2015). Optimization of conditions for plastein reaction and its application in improving the flavor of protein hydrolyzates from yellowfin tuna. J. Food Eng. Technol. 4:1-8.

Zhao, Y., Li, B., Liu, Z., Dong, S., Zhao, X. and Zeng, M. (2007). Antihypertensive effect and purification of an ACE inhibitory peptide from sea cucumber gelatin hydrolysate. Process Biochem. 42:1586-1591.

Zhao, Y. Q., Zeng, L., Yang, Z. S., Huang, F. F., Ding, G. F. and Wang, B. (2016b). Anti-fatigue effect by peptide fraction from protein hydrolysate of croceine croaker (Pseudosciaena crocea) swim bladder through inhibiting the oxidative reactions including DNA damage. Mar. Drugs. 14(221): 1-18

Zhu, K., Zhou, H. and Qian, H. (2006). Antioxidant and free radical-scavenging activities of wheat germ protein hydrolysates (WGPH) prepared with alcalase. Process Biochem. 41:1296-1302.

Ziauddeen, H. and Fletcher, P. C. (2013). Central nervous system biomarkers for antiobesity drug development. Drug Discov. Today. 18:1282-1291.

Zou, P., Wang, J., He, G. and Wu, J. (2014). Purification, identification, and in vivo activity of angiotensin I-converting enzyme inhibitory peptide, from ribbonfish (Trichiurus haumela) backbone. J. Food Sci. 79:C1-C7.

Zou, Y., Feng, W., Wang, W., Chen, Y., Zhou, Z., Li, Q., Zhao, T., Mao, G., $\mathrm{Wu}, \mathrm{X}$. and Yang, L. (2015). Protective effect of porcine cerebral hydrolysate peptides on learning and memory deficits and oxidative stress in lead-exposed mice. Biol. Trace Elem. Res. 168:429-440.

Zou, Y., Wang, W., Li, Q., Chen, Y., Zheng, D., Zou, Y., Zhang, M., Zhao, T., Mao, G., Feng, W., Wu, X. and Yang, L. (2016). Physicochemical, functional properties and antioxidant activities of porcine cerebral hydrolysate peptides produced by ultrasound processing. Process Biochem. 51:431-443. 